WHC-MR-0521

Revision 0

UC-900

\title{
The Plutonium Production Story at the Hanford Site: Processes and Facilities History
}

\author{
M. S. Gerber \\ Date Published \\ June 1996
}

Prepared for the U.S. Department of Energy

Assistant Secretary for Environmental Management

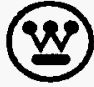

Manegement and Operations Contractor for the

U.S. Depertment of Energy under Contract DE-AC06-87RL10930

Approved for public release; distribution is unlimited 
c:

THIS PAGE INTENTIONALLY LEFT BLANK. 


\section{RELEASE AUTHORIZATION}

Document

Number:

WHC-MR-0521, Rev. 0

Document

Title:

The Plutonium Production Story at the Hanford site:

Processes and Facilities History

Release Date: $06 / 20 / 96$

This document was reviewed following the procedures described in WHC-CM-3-4 and is:

APPROVED FOR PUBLIC RELEASE

WHC Information Release Administration specialist:

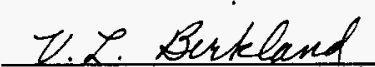

v. L. Birkland

$6 / 20 / 96$ 
THIS PAGE NTENTIONALLY

LEFT BLANK. 


\section{THE PLUTONIUM PRODUCTION STORY AT THE HANFORD SITE: PROCESSES AND FACILITIES HISTORY}

Michele Gerber, Ph.D.

June 1996

ABSTRACT

This document tells the history of the actual plutonium production process at the Hanford Site. It contains five major sections:
- Fuel Fabrication Processes
- Irradiation of Nuclear Fuel
- Spent Fuel Handling
- Radiochemical Reprocessing of Irradiated Fuel
- Plutonium Finishing Operations

Within each section, the story of the earliest operations is told, along with changes over time until the end of operations. Chemical and physical processes are described, along with the facilities where these processes were carried out. This document is a processes and facilities history. It does not deal with the waste products of plutonium production. 
WHC-MR-0521, Rev. 0

This page intentionally left blank. 


\section{TABLE OF CONTENTS}

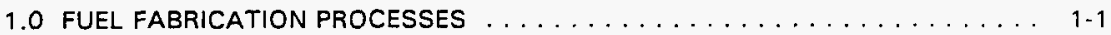

1.1 SINGLE PASS REACTOR FUEL FABRICATION $\ldots \ldots \ldots \ldots \ldots \ldots \ldots \ldots$

1.1 .1 Solid Uranium Metal Fuel Produced . . . . . . . . . . . . 1 1-1

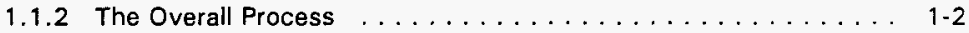

1.1 .3 Canning ............................. 1.3

1.1 .4 Canning Tests . . . . . . . . . . . . . . . . . . 1.4

1.1.5 Additional Chemical and Hazardous Components .......... 1-4

1.1 .6 Process Changes . . . . . . . . . . . . . . . . . 1-5

1.1.7 313 Building Expansion Under Eisenhower/Switch to

1.1 .8 Projection Fuel Elements $\ldots \ldots \ldots \ldots \ldots \ldots \ldots \ldots \ldots \ldots$ 1-6

1.1.9 End of Single-Pass Reactor Fuel Making . . . . . . . . . . . 1-7

1.1.10 Other $313 / 314$ Building Processes . . . . . . . . . . . 1-7

1.2 N REACTOR FUEL FABRICATION $\ldots \ldots \ldots \ldots \ldots \ldots \ldots \ldots \ldots \ldots \ldots \ldots \ldots$

1.2.1 The 333 Fuels Manufacturing Building .............. 1-10

1.2 .2 Co-Extrusion Process .................... 1-11

1.2.3 Other Processes in the 333 Building ............. 1-1.2

1.2.4 The Waste Acid Treatment System (WATS) Process . . . . . . . 1-12

2.0 IRRADIATION PROCESSING AT THE HANFORD SITE $\ldots \ldots \ldots \ldots \ldots \ldots \ldots$

2.1 HANFORD'S SINGLE PASS REACTORS . . . . . . . . . . . . . 2-1

2.1.1 Historic Significance of B-Reactor . . . . . . . . . . . 2-1

2.1.2 Single-Pass Reactor Buildings ................ 2-1

2.1.3 Operation of the Single-Pass Reactors ............. 2-2

2.1.4 Change and Experimentation in Production Process . . . . . . . . 2-3

2.1.5 Graphite Expansion Early Problem ... . . . . . . . . . . 2-4

2.1.6 Increased Power Levels/Production ... . . . . . . . . . . . . 2-4

2.1.7 Operating Challenges at Higher Power Levels . . . . . . . . . . 2-5

2.1.8 Reactor Upgrades for Increased Production . . . . . . . . . 2-6

2.1.9 End of Single-Pass Operations ............... 2-7

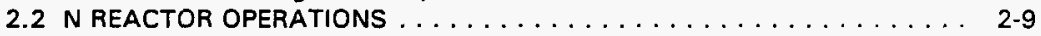

2.2.1 $105 \mathrm{~N}$ Building and Reactor ................ 2-9

2.2.2 N Reactor Operating Changes and Challenges .......... 2-10

3.0 SPENT FUEL HANDLING AT THE HANFORD SITE $\ldots \ldots \ldots \ldots \ldots \ldots \ldots \ldots$

3.1 ORIGINAL LAG STORAGE PRACTICES $\ldots \ldots \ldots \ldots \ldots \ldots \ldots \ldots \ldots$

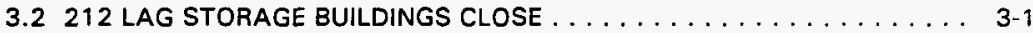

3.3 CLOSURE/RE-OPENING OF FUEL STORAGE BASINS . . . . . . . . . 3-2

4.0 RADIOCHEMICAL SEPARATIONS PROCESSING

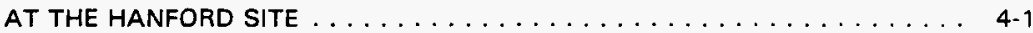

4.1 THE BISMUTH-PHOSPHATE PROCESS $\ldots \ldots \ldots \ldots \ldots \ldots \ldots \ldots$. $\ldots \ldots \ldots$

4.1.1 Start-up of Radiochemical Processing at HEW ... . . . . . . . 4-1

$4.1 .2 T, B$, and $U$ Process Groups ................ 4.1

4.1 .3 Original Separations Buildings . . . . . . . . . . . . 4 -1 


\section{TABLE OF CONTENTS (continued)}

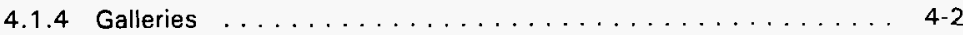

4.1 .5 Canyon .......................... 4 4.3

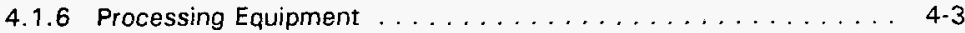

4.1 .7 Stair Towers ... . . . . . . . . . . . . . . 4 4-3

4.1 .8224 Bulk Reduction Buildings . . . . . . . . . . . . . . 4-4

4.1 .9231 Isolation Building . . . . . . . . . . . . . . . 4-5

4.1.10 The Bismuth-Phosphate Process . . . . . . . . . . . . 4-6

4.1 .11 Dissolving . . . . . . . . . . . . . . . . . . 4-6

4.1 .12 Extraction ..................... 4-6

4.1 .13 Decontamination .................... 4-7

4.1.14 224 Bulk Reduction Process ... . . . . . . . . . . . . 4-7

4.1 .15231 Isolation Process . . . . . . . . . . . . . . . . 4-7

4.1 .16 Earliest Operations . . . . . . . . . . . . . . . . . 4-8

4.1 .17 Early Process Changes . . . . . . . . . . . . . . . . . 4-8

4.1 .18 Operations Lessons Learned ... . . . . . . . . . . . . . 4 4 4

4.1.19 End of Bismuth-Phosphate Operations . . . . . . . . . 4-10

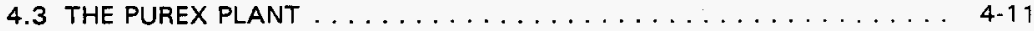

4.3.1 Genesis and Need for the PUREX Plant . . . . . . . . . . . 4-11

4.3.2 PUREX (202-A) Building .................. 4-12

4.3.3 Unique PUREX Design Features .............. 4-12

4.3.4 PUREX Production Output .................. 4-14

4.3.5 Long Shutdown Period for PUREX . . . . . . . . . . . . 4 4-15

4.3.6 PUREX Re-Start and Final Closure . . . . . . . . . . . . 4-16

4.3.7 Processing of Other Materials at REDOX/PUREX . . . . . . . . 4-17

5.0 PLUTONIUM FINISHING OPERATIONS AT THE HANFORD SITE $\ldots \ldots \ldots \ldots \ldots$. . . $\ldots$

5.1 STARTUP OF PLUTONIUM FINISHING OPERATIONS . . . . . . . . . 5 5-1

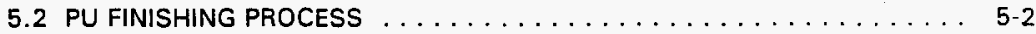

5.3 RMA (REMOTE MECHANICAL A) STARTUP, MODIFICATIONS . . . . . . 5-2

5.4 RMA LINE CHANGES $\ldots \ldots \ldots \ldots \ldots \ldots \ldots \ldots \ldots \ldots \ldots \ldots \ldots$

5.5 RMC (REMOTE MECHANICAL C) LINE CONSTRUCTED . . . . . . . . . 5-3

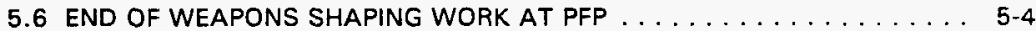

5.7 NON-DEFENSE WORK INTRODUCED TO PFP . . . . . . . . . . . . . 5-4

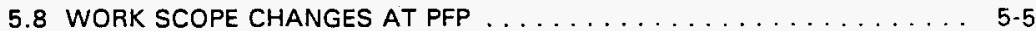

5.9 FINAL OPERATIONS AT PFP $\ldots \ldots \ldots \ldots \ldots \ldots \ldots \ldots \ldots \ldots$

\section{ENDNOTES}

BIBLIOGRAPHY 


\section{LIST OF PHOTOGRAPHS}

1-1 The 313 Metal Fabrication Building as it stood in $1945 \ldots \ldots \ldots \ldots \ldots$ 1-14

1-2 The 313 Building During Its 1954 Addition ................. 1-15

1-3 Autoclave Inspection Area in the 333 Building, $1984 \ldots \ldots \ldots \ldots \ldots$

1-4 N Reactor Fresh Fuel Being Loaded for Shipment to the Reactor

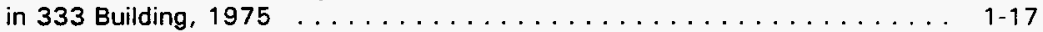

1-5 333 Building, New, Showing Tops of Autoclaves and

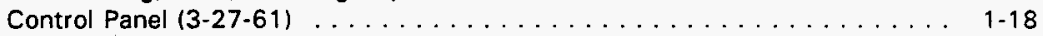

1-6 333 Building - Showing North Interior Wall of Chemical Bay - Under Construction $(1-24-61) \ldots \ldots \ldots \ldots \ldots \ldots$

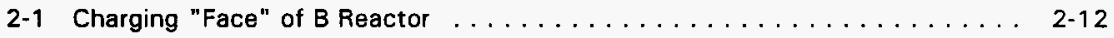

2-2 Graphite Layup for $C$ Reactor Core, $4-21-52 \ldots \ldots \ldots \ldots \ldots \ldots$

2-3 C Reactor, Mid-1950s ......................... 2-14

2-4 Front Face Area of KE Reactor, Showing Fresh

Fuel in Boxes Ready for Charging into the Reactor, 1960 s . . . . . . 2-15

2-5 K Reactor Workers Check Process Tubes, 1960 s . . . . . . . . . . . . . 2-16

2-6 N Reactor Front Charging Face, 1960s . . . . . . . . . . . . . 2-17

2-7 N Reactor and Support Buildings, 1970 s . . . . . . . . . . . . . . . 2-18

3-1 Construction of 212-N Lag Storage Building, 4-19-44 . . . . . . . . . . 3-4

3-2 N-Reactor Rear Face Spent Fuel Basin, 1980s, Showing Fuel at Bottom . . . . 3-5

3-3 N Reactor Spent Fuel Basin $\ldots \ldots \ldots \ldots \ldots \ldots \ldots \ldots \ldots \ldots$

4-1 T-Plant Under Construction, 1944, Hanford Site $\ldots \ldots \ldots \ldots \ldots \ldots$. . . . . . .

4-2 B-Plant Instrument Gallery, 1950 s . . . . . . . . . . . . . . 4-19

4-3 REDOX (202-S) Under Construction, 3-27-51 . . . . . . . . . . . . 4-20

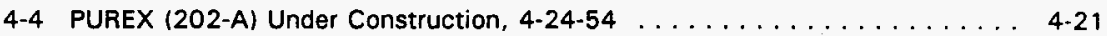

4-5 Interior of PUREX Plant Under Construction, $1954-55 \ldots \ldots \ldots$. . . . . . 4-22 


\section{LIST OF PHOTOGRAPHS (continued)}

4-6 PUREX Equipment Installation, $1954-55 \ldots \ldots \ldots \ldots \ldots \ldots$. . . . . . . . . 3

$5-1 \quad 231-Z$ Building Process Control Laboratory in WWII . . . . . . . . . . 5-6

$5-2$ Plutonium Finishing Plant, New in $1949 \ldots \ldots \ldots \ldots \ldots \ldots \ldots$

5-3 Equipment of the "RG" Line Being Removed from Hanford Site's Plutonium Finishing Plant in $1954 \ldots \ldots \ldots \ldots$. . . . . 5-8

$5-4$ Hanford Site's Plutonium Finishing Plant in $1963 \ldots \ldots \ldots \ldots \ldots$

5-5 Glovebox Used in Hanford Site Plutonium Finishing Plant's Plutonium Production, 1960 s $\ldots \ldots \ldots \ldots \ldots \ldots$

5-6 Plutonium Metal Button Produced

in the Plutonium Finishing Plant, 1980 s . . . . . . . . . . . . . . 5-11 


\section{THE PLUTONIUM PRODUCTION STORY AT THE HANFORD SITE: PROCESSES AND FACILITIES HISTORY}

\subsection{FUEL FABRICATION PROCESSES}

\subsection{SINGLE PASS REACTOR FUEL FABRICATION}

\subsubsection{Solid Uranium Metal Fuel Produced}

The nuclear fuel fabrication processes employed at the Hanford Site to manufacture plutonium (PU) for defense purposes essentially produced solid uranium (U) metal fuel elements, jacketed in aluminum-silicon (later Zircaloy-2)" coats. Although some variations were introduced, the solid metal fuel type was not replaced by powdered or pelletized fuel forms, nor by mixed oxide (MOX) fuel blends for the production of defense-grade Pu-239. Moreover, the fuel-making processes used at the Hanford Site for defense production ali were unique and prototypical at the time they were initiated. Thus, they qualify under criteria of the National Historic Preservation Act (NHPA) as historic processes.

1.1.1.1 Original Fuel-Making Buildings. The original fuel-making process employed at the Hanford Engineer Works (HEW-World War II name for the Hanford Site) was known as the "triple-dip" process. It took place in two buildings in HEW's 300 Area, known as the 313 Metal Fabrication Building and the 314 Press Building (also known as the Metal Extrusion Building). Both buildings were constructed of structural steel framing, had concrete block walls and concrete slab floors, and sat on reinforced concrete foundations. The 313 Building had a precast concrete slab roof with tar and gravel surface, and interior partitions made of concrete block and concrete brick. The 314 Building had a corrugated asbestos roof with a 36 -inch ( 91.44 centimeters) continuous roof ventilator extending nearly the entire length of the building. Interior walls consisted of concrete block with 3/16-inch asbestos board on some interior partitions.'

The original 313 Building, completed in the Autumn of 1943, was rectangular in shape, with overall dimensions of 199.5 feet ( 60.8 meters) by 65 feet (19.8 meters) by 20 feet (6.09 meters) (high). However, eight subsequent additions made in late 1943 and in 1944 brought the overall dimensions to 199.5 feet (60.8 meters) by 182.5 feet (55.6 meters) by 20 feet (6.9 meters) (high), with a total area of approximately 36,000 square feet $(3,344.4$ square meters). The continual early additions were caused by process improvements and changes in the very new, untried, and unique uranium fuel fabrication activities being carried out in the facility. According to prime construction contractor DuPont Corporation: "In the construction of the 313 Building, the first

- Zircaloy-2 is an alloy composed chiefly of zirconium, blended with small amounts of tin, iron, chromium and nickel. It is not a trademark product name. 
equipment to go into operation was known as the experimental line. This line was set up specifically for experimental purposes...[and] was dismantled and moved to other portions of the...Building." 2

The first 313 Building addition, on the east side, provided additional space for furnaces and presses, and the second, on the west side, provided a tool room and shop. The third addition ran the entire east side of the building, and allowed space for welding booths and jacket (can) washing. The fourth addition, on the northwest corner, furnished an electrical control room, and the fifth addition, along the west side, included a locker room, women's rest room, and shower room. (The locker and shower rooms later were eliminated in favor of a storeroom.) The sixth addition was again on the northeast corner of the facility, and provided more space for can washing. The seventh addition, on the southeast of the building, allowed for a second canning process section and for "recovery" (uranium scrap recycling) process equipment. However, this latter equipment soon was moved to the nearby 314 Press Building. The eighth and final addition of WWII was on the northeast corner, and furnished space for a third canning process section. ${ }^{3}$ The 313 Building contained numerous electrical furnaces and metal presses; three fuel canning areas; a welding area; a can cleaning area; a control room; various supply tanks; a tool room and shop; and various offices, storerooms, and sanitary rest rooms.

The 314 Press Building had original overall dimensions of 199.5 (60.8 meters) feet by 90.5 feet ( 27.58 meters) by 40 feet (12.19 meters) (high) with an area of about 17,000 square feet (1579.35 square meters). It contained a 1,000-ton extrusion press, electric furnaces, a rod-straightening machine, a 7.5-ton overhead crane, an autoclave area, a control room, a shop and repair area, pumping units for the press, and various offices and sanitary rest rooms. Outside, there was a 12 -foot (3.66 meter) by 18 -foot (5.49 meters) concrete and steel platform north of the building. Gas cylinders were located outside along the north wall. ${ }^{4}$

\subsubsection{The Overall Process}

Hanford's original fuel-making processes can be summarized as follows: It began in the 314 Building, where uranium that arrived as billets was heated in a muffle-type furnace with an interior, inert gas atmosphere. (The helium or argon atmosphere was used to reduce the oxidation of metal during heating.) The uranium was then transferred through a closed passageway to the extrusion press, which also operated in an inert atmosphere. After being extruded, the rods were outgassed, straightened, and sent to the 313 Building for machining and jacketing. In the $\mathbf{3 1 3}$ Building, $U$ fuel rods were machined into fuel cores in lengths of either 4 inches $(10.16$ centimeters) or 8 inches (20.32 centimeters), with 1.3-inch (3.3 centimeters) inner diameters. Known as "slugs," these cores were "canned" or jacketed into finished elements, and then tested and inspected in this building.

Details of the HEW fuel-making process provide valuable insights: The earliest uranium for the fabrication of reactor fuel arrived at the HEW in October 1943 as extruded rods. The rods were delivered to the Riverland Yards. The Riverland Yards were an official part of HEW and were located just east of the Midway power substation (just west of the 100-B Reactor Area). Because railroad track had not yet been completed to the 300 Area, the rods were taken by rail to the Hanford Construction Camp about 20 miles 
(32.19 kilometers) north of Richland, and then by truck to the 300 Area. Once railroad service to the 300 Area was connected in January 1944, uranium was delivered to the fabrication area by rail.

Newly arrived $U$ rods were unpacked and visually inspected (in sample amounts) for cracks and for overall dimensions. A random amount from each lot was taken to the 305 Test Pile Building just west of the 313 Building, and irradiated at a low level to check for warping, cracking, and embrittlement under irradiation. If the sample withstood the process in good form, the entire lot was accepted. Beginning in December 1943, the first uranium fabrication operation at HEW was machining, in which bare uranium rods were lathed down to specific core dimensions in the 313 Building. The following month, operators began degreasing the machined cores before inspection, using a commercial product that contained primarily trichloroethylene, Detrex', a solvent degreaser. Core canning operations actually began in the 313 Facility in March 1944.

In the 314 Building, autoclaves for fuel element testing started to operate in July 1944. A scrap recovery process began the following month. Outgassing and straightening operations started in the 314 Building in September 1944, but HEW's uranium rods still were being extruded offsite. Beginning in November 1944, uranium was transported to HEW as billets, which were stored until the extrusion process began to operate in the 314 Building in January 1945. The press testing phase lasted into mid-spring, and then fuel operations commenced. Greater confidence in personnel performance ended shift work in the metal preparation buildings in June 1945, and work proceeded on a straight, 6-day-per-week schedule. From that time until 1948, a complete cycle of metal preparation occurred at HEW. The uranium billets went to the 314 Building for extrusion, outgassing, and straightening, then to the 313 Building for machining, canning, and initial inspection, and then back to the 314 Building for autoclave and radiograph testing. ${ }^{5}$

\subsubsection{Canning}

The original fuel canning process tried at HEW involved the use of an electric heater press, known by workers as the "whiz-bang," to heat and bond the uranium fuel cores to their aluminum jackets. However, the heaters burned out frequently, did not heat the elements and cans to consistent temperatures, and did not produce a uniform bonding. This problem was serious because nonuniform bonding caused thin places in the jacketing that, under irradiation, heated up more than other places. These "hot spots" could cause fuel element ruptures in the reactors. By August 1944, the uranium fuel cores were being jacketed in a triple-dip method that consisted of bathing them in molten bronze, tin, and then a molten aluminum-silicon mixture. The bronze used in this process at HEW was relatively high in tin content $(53 \%$ tin and $47 \%$ copper), and the bronze bath itself had a flux cover composed of barium chloride, potassium chloride, and sodium chloride. As fuel cores were dipped into this mixture, they acquired trace coverings of all of these substances.

"Detrex is a trademark of Detrex Chemical Industries. 
Initially, the bare uranium cores were cleaned by passing them through a trichloroethylene vapor degreaser, then through a nitric acid tank, two rinse tanks, and a hot air dryer. The nitric acid rinse was known as "pickling" the slugs. Meanwhile, a steel "sleeve" that would surround each can during the dipping process was cleaned in sodium hydroxide, and aluminum end caps and cans were cleaned in a sodium dichromate solution followed by a methanol rinse. The bare uranium cores were dipped in a bronze bath to heat them to a uniform temperature within the uranium beta phase $\left(660^{\circ} \mathrm{C}\right.$ to $\left.770{ }^{\circ} \mathrm{C}\right)$, and then placed in a tin bath to (1) cool them into the uranium alpha phase (less than $660^{\circ} \mathrm{Cl}$ and $(2)$ remove excess bronze. Next they were centrifuged to throw off excess tin. Then the cores were immersed quickly in an aluminum-silicon brazing bath (also in the uranium alpha phase), and water quenched. The various heating and cooling procedures were done to randomize the uranium grains, thus inhibiting the uranium "growth" (expansion under irradiation) problem. After water quenching, the steel sleeve was pulled away and cleaned with sodium hydroxide and soap to remove any remaining aluminumsilicon. The sleeve then could be reused many times. The thickness of the residual end cap on the element was then measured with a fluoroscope and marked with a punch to indicate the amount that needed to be removed in subsequent end machining. Identification numbers were stamped on the can base end, and the braze line on the end cap was tungsten inert gas (TIG) welded to seal the porous braze to the end cap and can. A final etching in nitric acid completed the procedures.

\subsubsection{Canning Tests}

Three tests followed the canning process. The first, the frost test, consisted of spraying the can with acenaphthene mixed with carbon tetrachloride $\left(\mathrm{CCl}_{4}\right)$. The canned element was then placed into an induction coil to heat its surface. If there was a gas bubble or a nonbonded spot, this spot would become shiny, and the element then would be rejected and sent back through a recycling process. If the bond was good, the acenaphthene was removed with trichloroethylene, and the element was inspected in one of several autoclaves located in the 314 Building. In that inspection, the canned element was placed into a steam autoclave, which operated at about 100 pounds (45.36 kilograms) per square inch gauge (psig) at $175^{\circ} \mathrm{C}$ for more than 20 hours, to reveal any pinholes or incomplete welds. Water from the steam would be conducted through any such openings, and the uranium core would expand rapidly, resulting from the formation of a uranium oxide $\left(\mathrm{UO}_{2}\right)$ compound known as $\mathrm{U}_{3} \mathrm{O}_{8}$, and split the aluminum can. If an element passed the autoclave test it then underwent a final radiograph ( $X$-ray) test in the 314 Building, to detect porosity in the end weld bead. Any porosity could have become a pathway for water to contact the uranium fuel and cause the element to rupture. $^{6}$

\subsubsection{Additional Chemical and Hazardous Components}

In addition to the above-mentioned chemicals, other hazardous substances were used routinely in early HEW fuel fabrication processes. Aluminum cans and caps were 
cleaned using first trichloroethylene, then Duponol-M-3 $3^{\circ}$ (an industrial soap), phosphoric acid, and various rinses including methanol. Steel sleeves were cleaned in sodium hydroxide and soap. Caustic cleaners popular at HEW included Aluminux and Diversey- $415^{\mathrm{b}}$, both containing primarily sodium dichromate. Sodium hydroxide and sodium nitrate were used to strip aluminum and braze off the rejected uranium cores. An intermetallic compound layer of uranium and copper (specifically $\mathrm{UCu}_{5}$ ) on the rejected cores was removed by using hydrofluosilicic acid. Acetone and methyl alcohol (methanol) were used as all-purpose cleaning and drying agents.

\subsubsection{Process Changes}

In 1948, the extrusion press in the 314 Building was excessed, and HEW began receiving rolled uranium rods from an offsite commercial mill. The rolling process seemed to offer metallurgical advantages, because the uranium could be processed at lower temperatures, which induced less oxidization and produced smaller and more random grains within the metal. This type of grain within the uranium avoided the "pimpling and dimpling" of fuel rods, a persistent problem in early fabrication efforts. It was also a less expensive process. From 1950 to 1951 , a rolling mill was procured and installed in the 314 Building, to save the costs of shipment to offsite mills. However, this mill was relatively small, and the rolling operation was transferred to a large facility constructed at the Feed Materials Production Center (FMPC), an Atomic Energy Commission (AEC) site in Fernald, Ohio, in 1952. Thereafter, no extruding or rolfing operations were conducted at the Hanford Works (HW - the peacetime name given to HEW in 1947 by the AEC) in connection with the fabrication of fuel elements for single-pass reactors. The 314 Building process continued to operate for the purposes of straightening uranium rods, providing autoclave and radiograph testing of canned elements, and providing uranium scrap processing operations. ${ }^{\text {? }}$

\subsubsection{Building Expansion Under Eisenhower/Switch to Lead-Dip Process}

In 1954, the 313 Building underwent a major remodeling and expansion, reaching a total size of 182.5 feet ( 55.63 meters) by 486 feet (148.13 meters), with a total area of 76,633 square feet (7119.44 square meters). At that time, much contaminated equipment and other solid wastes from this building and its immediate surrounding area and from the 303 fresh fuel warehouses were buried. The remodeling occurred at the time that fuel canning technology in the 313 Building switched from the triple-dip process to the new lead-dip process. Lead-dip consisted of immersing the uranium fuel cores in a duplex bath (molten lead covered with molten aluminum-silicon) to preheat the cores in the uranium alpha phase. This step formed an intermetallic compound of uranium and lead (UPb or $\mathrm{UPb}_{3}$ ) on the core. It was followed by a molten aluminum-silicon bath (also in the uranium alpha phase) to braze and bond the cores to the aluminum cans and caps. This

-Duponol-M-3 is a trademark of the E.I. du Pont de Nemours \& Company.

Aluminux and Diversey-415 were both trademark products of the Diversey Chemical Corporation. 
process allowed the first canning bath to occur at a lower temperature (lower than $660^{\circ} \mathrm{C}$ ) because the uranium cores already had been beta heat treated in a molten salt bath at the FMPC. However, the new method introduced a great deal more lead and other heavy metals into 313 Building waste streams, because approximately 30,000 fuel elements were canned per week during the years of peak single-pass reactor operations at HW (1955-1964). At about the same time that the lead-dip process replaced the triple-dip method, an ultrasonic test replaced the frost test, which eliminated the use of acenaphthene and $\mathrm{CCl}_{4}$. Concurrently, the majority of testing autoclaves were removed from the 314 Building and placed in the north end of the 313 Building.

1.1.7.1 Hot Die Size Process. In the early 1960's, just before the eight single-pass reactors at $\mathrm{HW}$ began to close, experiments were under way in the 304,3716 , and 313 Buildings with a new canning procedure known as the Hot Die Size Process. Also termed the "nickel-plate" procedure, this operation plated uranium fuel cores with nickel, using nickel sulfate, nickel chloride, and boric acid. It included standard fuel fabrication cleaning, degreasing, etching, and testing chemicals and processes. Although the Hot Die Size method was tested successfully, it was not implemented on a large scale, because of the impending closures of HW's eight original reactors. ${ }^{8}$

\subsubsection{Cored and Internally and Externally Cooled (I\&E) Fuel Elements. In the} 313 Building, additional fuel fabrication process changes during the 1950's and early 1960 's included the manufacture of cored fuel rods beginning in 1954, internally and externally cooled (I\&E) fuel rods beginning in 1957, and projection fuel rods in the early 1960 's. The cored rods, hollow elements with an aluminum plug at either end, bonded to the uranium with an aluminum-silicon braze, were designed to give the uranium an inner space in which to expand during irradiation. The early, solid fuel elements were experiencing a troublesome level of distortion, and subsequent rupture, in HW's production reactors. However, the cored fuel elements frequently developed cracks in both the uranium and the aluminum plug areas, and they were discontinued in 1957. The I\&E fuel elements, tried next, had a tubular hole down the middle, allowing cooling water to run both around and through them in the reactors. Projection fuel elements, with small fins protruding from their sides, were of two types: the bumper type had six short projections for use in ribbed process tubes, and the self-supporting type had eight projections for use in ribless process tubes.

\subsubsection{Projection Fuel Elements}

The switch to projection fuel rods represented yet another attempt to solve the fuel element rupture problem then plaguing Hanford's eight single-pass reactors. Power and fuel exposure level increases throughout the late 1950's and early 1960's had brought reactor operating temperatures to a point that seriously augmented fuel rod ruptures, with resultant increases in contamination released to the Columbia River. Post-irradiation examinations of failed I\&E fuel elements showed that only about $20 \%$ of the failures resulted from fuel element "quality deficiency," while $80 \%$ resulted from longitudinal corrosion attack caused by warp. Known as "side hot-spot" ruptures, these failures were caused by positioning of the fuel rods in the process tubes. The new projection fuel elements, first tested in 1961 in reactors at HW, were manufactured in the 313 Building through the use of ultrasonic welding. Canned fuel elements first were dipped in a tank to 
deposit an Ivory soap film, useful in achieving a good weld. After the projections were welded, the soap film would be rinsed off in a three-compartment rinse using standard fuel fabrication chemicals and degreasers. ${ }^{9}$

\subsubsection{End of Single-Pass Reactor Fuel Making}

Fuel element preparation activities for the single-pass reactors ended in the 313 and 314 Buildings in 1971, when the last of these reactors closed. The 314 Building was modified in the 1970's and was used for a variety of research projects and crafts services. The majority of the fabrication equipment for single-pass reactor fuel elements was removed from the 313 Building between the mid-1970's and the mid-1980's. However, the south end of the 313 Building continued to house major functions in support of $\mathrm{N}$ Reactor fuel production. Among these functions were the receiving and inspection of uranium billets and other components used to make $\mathrm{N}$ Reactor fuel elements and the chemical passivation of spacers from $N$ Reactor, the casting and machining of copper-silicon preshape components used in N Reactor fuel elements (beginning in 1973), and the neutralization and handling of non-uranium-bearing acid wastes from $N$ Reactor fuel fabrication processes in the 333 Building. Finished $N$ Reactor fuels and fabrication components, tools, and miscellaneous supplies were stored in the north end of the 313 Building from 1971 to 1987, and an Engineering Development Laboratory, including facilities for working with uranium, was established in the structure in the 1970's. In $1983 / 1984$, a Sutton ${ }^{b}$ extrusion press was purchased and placed in the 313 Building as a backup for the extrusion press operating in the 333 Building performing $N$ Reactor fabrication work. However, the shutdown of N Reactor operations in December 1986 precluded use of the Sutton press.

\subsubsection{Other 313/314 Building Processes}

Over the years, several other ancillary or off-shoot processes have taken place in the 313 and 314 Buildings. Among these have been $U$ scrap recovery operations, experimental and/or small-scale fuel making ventures, and waste treatment procedures. From its earliest days, concern of the Manhattan Engineer District (MED - earliest federal management agency over HEW) about the adequacy of uranium supplies brought strict policies that mandated the reclamation of all possible uranium scraps at federal atomic sites. During the earliest fuel fabrication operations at HEW, difficulties with early fuel canning techniques produced thousands of rejected cores, lathe turnings, metal oxides that formed when canned slugs failed in autoclave tests, and other scraps by mid-1944. That June, Du Pont reported that "all available space" around the 313 and 314 Buildings was filled with cans of scrap, and the fabrication area fence had to be moved about 30 feet (9.14 meters) east of fresh fuel storage building 303-J to allow for more storage space.

Ivory is a trademark of the Proctor and Gamble Co., Cincinnati, Ohio.

'Sutton is a trademark of the Sutton Engineering Corporation, Pittsburgh, PA. 
Several can fires occurred. Beginning with the startup of extrusion press tests in January 1945, extrusion butt ends, oxides, and container residues collected, along with acids from the slug pickling process and from the slug recovery process. ${ }^{10}$

At first, the various types of scrap were shipped to offsite reclamation processing centers. By 1946, however, the volume of uranium scraps accumulating and the expense and fire and security hazards of shipment brought a change in policy at HEW. A "chip recovery" operation began in the 314 Building. It operated only a few days a month and involved collecting all chips and turnings from machining operations, sorting them, breaking them into small pieces, washing, drying, and then pressing them into briquettes. At first the briquettes themselves were shipped offsite. In May, however, the MED ordered briquetting to be discontinued, due to a number of uranium chip fires within the centrifuging step at other sites. A "melt plant" was established in the 314 Building in late 1947. In that process, "new" uranium could be made by combining uranium tetrafluoride $\left(\mathrm{UF}_{4}\right.$ or "green salt") and either calcium chips or magnesium chips. This mixture was placed in a dolomite-coated steel vessel, heated until free molten uranium separated from magnesium fluoride or calcium fluoride, and then allowed to cool. The molten uranium settled into large buttons shaped like Derby hats (called "Derbies" by HW workers). Slag was jackhammered off the Derbies, which were mixed with the recycled uranium scraps and briquettes, melted in a vacuum furnace, and cast into ingots. These ingots were then rolled into new uranium rods, either offsite or at Hanford, and used to make additional fuel rods.

In the spring of 1946, an additional scrap recovery operation known as the "oxide burner" began on the north side of the 314 Building. All uranium-bearing dust and particulate matter that could be collected from the fuel fabrication facilities, as well as the tailings or settlings from washes and quenches, was burned to convert it to oxide (powder) form. The $\mathrm{UO}_{2}$ was then collected in 5 -gallon (18.93 liters) buckets for compact shipment offsite. ${ }^{11}$

From the outset of chip recovery operations in 1946, HW's Health Instruments (H.I.) Division detected serious radiological problems with this process. Throughout 1946 and 1947, monitors reported that oxide burner operations were really spreading metal dust and oxide around the 314 Building, producing airborne contamination samples over tolerance. ${ }^{12}$ In December 1947, the oxide burner operation moved to a separate building north of the 314 Building. ${ }^{13}$ Both melt plant and oxide burner operations were phased out at HW between 1952 and 1954. The burnout of slag from used melt crucibles was completed, and the furnace was excessed to the 300 Area Burial Grounds by late summer 1954. Thereafter, solid uranium scraps at HW continued to be collected, stored, and combined with solids collected from neutralized, uranium-bearing waste acids and processed through a press-and-frame filter press in the south end of the 313 Building. Together, all of these scraps were slurried into sodium diuranate, stored in the 303 Buildings area, and shipped in barrels to the FMPC. ${ }^{14}$

From 1944 through the 1950s, bismuth fuel targets welded into nonbonded aluminum cans, irradiated to make polonium-210 in 100 Areas production reactors, were fabricated in the 313 Building. Polonium-210 was the initiator in atomic (pre-hydrogen and non-hydrogen) weapons explosions. An even larger number of lead-cadmium fuel rods, also welded into nonbonded aluminum cans, were produced for use as "poison" elements 
in the 100 Areas reactors and in the 305 Test Pile. The term "poison" refers to the ability of these neutron absorbing metals to slow down or even kill (control) nuclear chain reactions. The production of lead-cadmium fuel rods continued throughout the years of single-pass reactor operations (through 1971). Additionally, lithium-aluminum alloy fuel targets, manufactured for the P-10 project at Hanford's 100-B Area to produce tritium for the world's first hydrogen weapons tests, were canned in nonbonded aluminum cans in the 313 Building from 1949 to 1952.

During the early 1950s, a number of attempts were made to fabricate and jacket metallic thorium fuel targets in the 313 Building to produce uranium-233. Many problems connected with the rapid formation of a thick coat of oxide on the thorium metal targets led to experiments with a variety of bonding methods and coatings. Eventually, thorium oxide $\left(\mathrm{ThO}_{2}\right)$ powder and wafer fabrication was carried out in the nearby 3722 and 3732 Buildings in the late 1960's. Beginning in the late 1950s and continuing until 1971, a process to electrolytically anodize the aluminum "spacers" (dummy fuel elements) used in the single-pass reactors (to create a protective aluminum oxide $\left[\mathrm{Al}_{2} \mathrm{O}_{3}\right]$ coating) was added in the 313 Building. The passivation of $\mathbf{N}$ Reactor steel spacers to reduce rust formation also took place in the 313 Building from the mid-1960s through the mid-1980s. ${ }^{15}$ Aiso, highly enriched uranium-aluminum fuel cores, used as driver elements in the early tritium production program and in a mid-1960's uranium-233 production program in the $\mathrm{N}$ Reactor, were manufactured and canned in nonbonded aluminum cans in the 313 Building.

Beginning in 1954, waste acids containing recoverable amounts of uranium from the 313 and 333 Buildings were routed to designated tanks in the 313 Building, neutralized, routed to another tank, and passed through a press-and-frame filter press. The precipitate remaining on the filter press was known as " $\mathrm{C}-6$ " sludge, and was collected and placed in barrels for shipment to the FMPC. The centrifuging operation, along with waste acid storage tanks, anodizing tanks, and the filter press used to separate sodium diuranate from uranium-bearing, neutralized wastes, was located in the south end of the 313 Building. A process to recover uranium cores from rejected, lead-dip canned fuel elements also began in the south end of the 313 Building in 1954. Boiling sodium hydroxide was used to remove the intermetallic compound layer of lead and uranium from the elements. Beginning in 1975, the 313 Building played a key role in a new Waste Acid Treatment System (WATS) process that was emplaced in connection with the nearby 333,334 and 334A Buildings. The WATS process operated until 1987.

\subsection{N REACTOR FUEL FABRICATION}

The fuel-making process for the New Production Reactor (N Reactor) was very different from that used to make fuel for Hanford's single-pass reactors. Soon after funding was secured for $N$ Reactor in 1958, a high pressure heat transfer apparatus was emplaced in the 189/190-D Building, a converted World War II pumphouse in the Hanford Site's 100-D Area. Its purpose was to test a new, N Reactor fuel concept being developed in the 306 Metallurgical Pilot Plant, a 300 Area building dedicated to fuel manufacturing experimentation. The concept first tried for $N$ Reactor fuel was a wirewrapped, seven-element cluster of long, thin fuel rods spaced together in a horizontal flow tube. Each individual element was only 0.625 to 0.704 inches (1.59 to 1.79 centimeters) 
in diameter, and was 35 to 45 inches ( 88.9 to 114.3 centimeters) long. As such, the heat transfer and flow properties of these elements were very different from those of the solid $U$ or I\&E fuel elements previously used at Hanford. An understanding of every characteristic of the new elements, including subcooled and boiling burnout and pressure drop parameters, was essential if they were to be recommended for $N$ Reactor use, so trials continued throughout $1959 .^{16}$ However, attention soon turned to yet another new concept developed in the 306 Building. This idea, of a co-extruded tube-in-tube fuel element design, eventually was adopted for $N$ Reactor. A full-scale, experimental heat transfer test section that simulated the downstream half of a tube-in-tube charge in N Reactor was built on the mezzanine of the 189/190-D "flow laboratory." 17

\subsubsection{The 333 Fuels Manufacturing Building}

In the meantime, construction of the new 333 Fuels Manufacturing Building, to produce $N$ Reactor fuel elements on a plant scale, was being constructed just east of the 313 and 314 Buildings. Building design itself did not depend on knowing exactly which manufacturing process would be used, but once the co-extrusion process was selected, the equipment eventually procured and constructed in the 333 Building was unique. The 333 Fuels Manufacturing Building itself was constructed of steel frame with double metal insulated panel exterior walls and lightweight metal panels for interior partitions. The foundation and floors were poured concrete. The roof consisted of insulated metal paneling covered with felt and roll tarpaper and a tar and gravel surface. The roof was refinished in 1962. The structure was 300 feet ( 91.44 meters) by 140 feet (42.67 meters), with a total area of 48,817 square feet ( 4535.25 square meters). In 1980 , in response to anticipated increases in production, a small addition was placed on the northwest corner of the 333 Building. It consisted of two stories; the ground level an open bay shop and the second story for offices. The addition was 33 feet (10.06 meters) by 104 feet ( 31.70 meters), and runs from the HVAC (heating, cooling and ventilating) supply units on the west side of the building to the north exterior wall.

A majority of the 333 Building was a large, one story, open bay housing large machinery for fuel-making, but the structure also contained two mezzanines. The larger mezzanine ran along the east wall and housed distribution equipment and offices. The smaller central mezzanine housed ventilation equipment for the chemical bay. Air conditioning and heating of the building originally was accomplished with steam heat and evaporation cooling forced air equipment located in a 30 -foot ( 9.14 meters) by 75 -foot (22.86 meter) enclosure adjoining the west side of the building. During 1979-80, some energy conservation upgrades and cleanouts were made in this system. New heat recovery systems were installed. The 333 Building has always been equipped with electrical fire detection mechanisms and an automatic sprinkler system. The co-extrusion process was carried out with various equipment pieces, but the most prominent and unique of these was a Loewy Press that actually pressed all of the fuel components (U core and all of the cladding components) together in one unit. Each $\mathrm{N}$ Reactor fuel element was 26 inches (66.04 centimeters) long, weighed approximately 52 pounds (23.59 kilograms), and had a tube-in-tube configuration with a coolant channel running down the entire length of the element. Projections also were welded onto each element, as the N Reactor process tubes were smooth or "ribless." The co-extrusion process 
WHC-MR-0521, Rev. 0

provided a better, more uniform bond between core and jacket that had been possible with older methods based on dipping. The new method was beneficial in smoothly cladding the inner and outer tubes so that they would fit together without developing "hot spots."

\subsubsection{Co-Extrusion Process}

The co-extrusion process began with inspection and cleaning of copper and coppersilicon pre-shapes and backing plates used in the process. The cleansing agents were nitric acid, nitric hydrofluoric, and chromic nitric sulfuric acid. Next, cladding components made from Zircaloy-2 were degreased, rinsed in nitric and hydrofluoric acid, and dried with forced-air heating. In the meantime, $U$ biliets were degreased with perchloroethylene, etch with nitric acid, rinsed, dried and inspected. Next, the copper, copper-silicon, Zircaloy-2, and $U$ components were assembled and welded into a billet assembly. This assembly was evacuated of air, leak tested, sealed preheated, and then co-extruded (squeezed together) in the Loewy Press. As the process specifications for this step emphasized: "The quality of the extruded tube is dependent upon many things, not the least of which is skill, care, effort,and precision that are put into the co-extrusion operation. "18

The process of cleaning, degreasing, etching and drying components, then assembling and pressing them, was repeated for both the outer (larger) and inner (smaller) tubes that made up the tube-in-tube configuration. The extruded tubes then exited the press to a roll-out table where they were rolled continuously for at least six minutes to prevent tube deformation and non-uniform cooling. Next they were sectioned to the specified length, and the ends were machined to create fuel sections or elements. Nitric acid was used to remove copper silicon residues, and nitric sulfuric acid was used to chemically mill (i.e., dissolve away) excess uranium on fuel element ends. Elements then were etched with nitric hydrofluoric and nitric acid, and brazed with an etched braze ring material consisting of Zircaloy-2 alloyed with about five percent beryllium. (This braze material previously had been degreased and etched.) The brazed elements were heattreated in a molten salt bath to randomize the $U$ grain structure to prevent preferential grain growth that could rupture the elements in the reactor.

The next step in the process was to weld projections or supports onto the fuel elements. Eight lengthwise protrusions were attached to the outer surface of each fuel element, evenly spaced around its diameter. This configuration allowed cooling water to circulate optimally around the elements, without creating hot spots where the sides of elements rested too close to the inner walls of the process tubes. After projections were welded onto the elements, the two tubes (inner and outer) had to be attached together. Support hardware was attached to the outer surface of the inner tube, and locking hardware was affixed to the inner surface of the outer tube. The two tubes then were given a final nitric hydrofluoric acid etc, separately tested in autoclaves, inspected, assembled and interlocked, and stored as finished fuel. The coextrusion process was carried out continuously in the 333 Building from 1960 until December 1986, reaching a peak volume of approximately 250 finished fuel elements per week in the mid-1980s. ${ }^{19}$ 


\subsubsection{Other Processes in the 333 Building}

From 1965 to 1967 , the 333 Building performed autoclave testing, final etching with nitric-hydrofluoric acid, and inspection of special lithium aluminate fuel targets made in the nearby 3722 Building for the production of tritium. Highly enriched $12.1 \%$ uranium-235) uranium driver fuel elements for tritium programs also were made in the 333 Building from 1965 to 1970 .

\subsubsection{The Waste Acid Treatment System (WATS) Process}

In 1971, a study of radioactive releases and special materials accounting practices identified several areas of concern in 333 Building operations. Among these concerns were the amounts of contaminated gaseous, particulate and liquid discharges, and the need for expansion of monitoring and sampling systems. Partly in response to these concerns, the Waste Acids Treatment System (WATS) process was developed, a new system to catch and neutralize waste acids from the structure's fuel-making processes. In 1973, the WATS began partial operations to treat waste acids from 333 Building operations. It operated for four months in 1973 and became fully operational in January 1975. The 300 Area WATS process represented a method to prevent 333 Building fuel fabrication bulk waste acids from discharging to the 300 Area process sewer.

Tanks and control instruments for the WATS system were located in and below the 334-A Waste Acid Storage Facility, a small steel frame structure that was moved in close to the 333 Building, from Hanford's 200 Area. The portion above grade was used for general storage of products and absorbents, and the portion below grade contained three tanks seated in a reinforced concrete pit 18.5 feet ( 5.64 meters) by 18.3 feet (5.58 meters) by 10 feet ( 3.05 meters) (deep). Additional tanks and piping components for the WATS system were located in the 313 Building, the 333 Building, the 334 Chemical Handling Facility next door to the 333 Building, and in the nearby 311 Tank Farm. The 303-F Building, also nearby, served as the pumping station for the various liquid and slurry waste transfers in the WATS process. During most of the years of WATS operation (1975 to 1988) the tanks in the 334-A Building received approximately 210,000 gallons (794 936.492 liters) of waste acids per year. ${ }^{20}$

The waste acids treated in the WATS operation included nitric, sulfuric, hydrofluoric, and chromic-nitric-sulfuric acids bearing uranium, Zircaloy- 2 components, copper, beryllium, and other fuel fabrication materials. Waste acids were collected in the 334-A Building tanks and then pumped to the 313 Building for neutralization with sodium hydroxide. Wastes containing recoverable amounts of uranium were routed directly from the 333 Building to the 313 Building and were not treated as part of the WATS process. Waste acids containing nonrecoverable amounts of uranium were pumped to the 313 Building for neutralization and, beginning in 1985, were centrifuged to remove solids. Solids from the centrifuge were placed in drums and transferred to the 303-K Radioactive Mixed Waste Storage Facility or to the Central Waste Complex in Hanford's 200 West Area for eventual disposal. Filter press effluent and centrifuge effluent from 313 Building operations then was pumped to the 311 Tank Farm for storage and transported to 
Hanford's 100-H Area for evaporation. Beginning in 1985, some neutralized waste effluents from the 333 Building were shipped from to Hanford's 340 Retention and Neutralization Complex for transshipment to the 200 Areas or offsite for disposal. ${ }^{21}$ 
Photograph 1-1. The 313 Metal Fabrication Building as it stood in 1945.

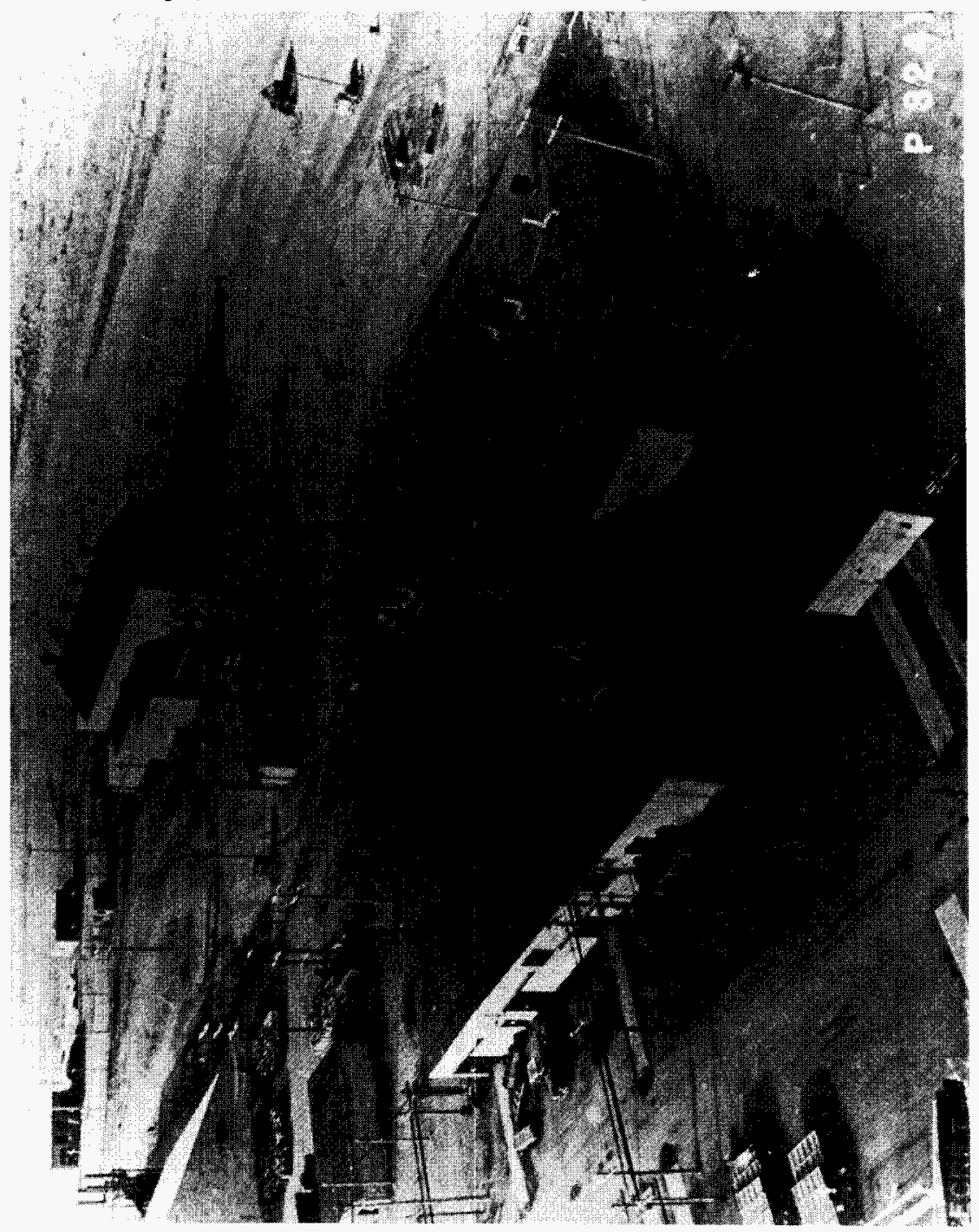


Photograph 1-2. The 313 Building During Its 1954 Addition. The new construction on the north end, extended the structure from 200 feett in length to 490 feet.

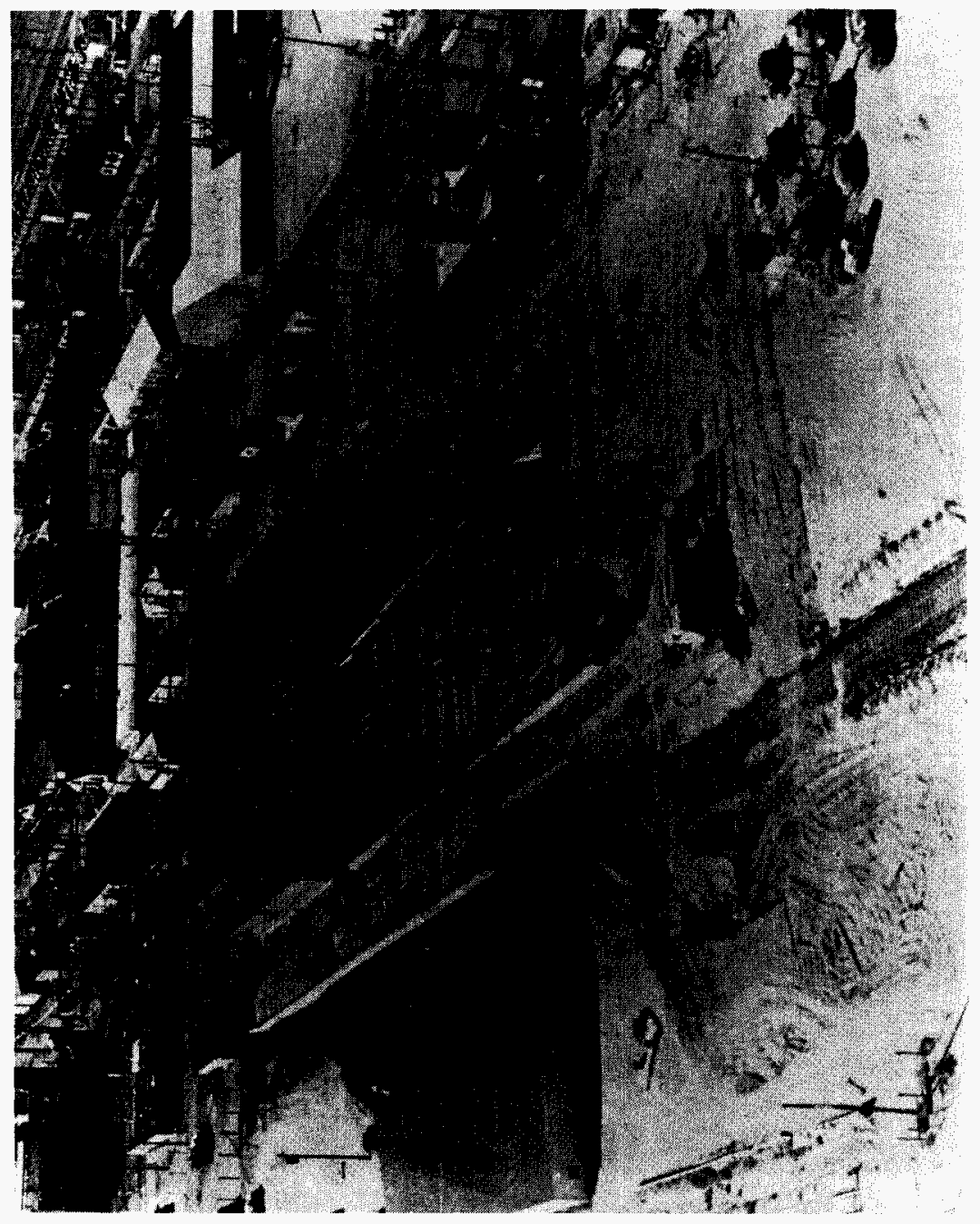


Photograph 1-3. Autoclave Inspection Area in the 333 Building, 1984.

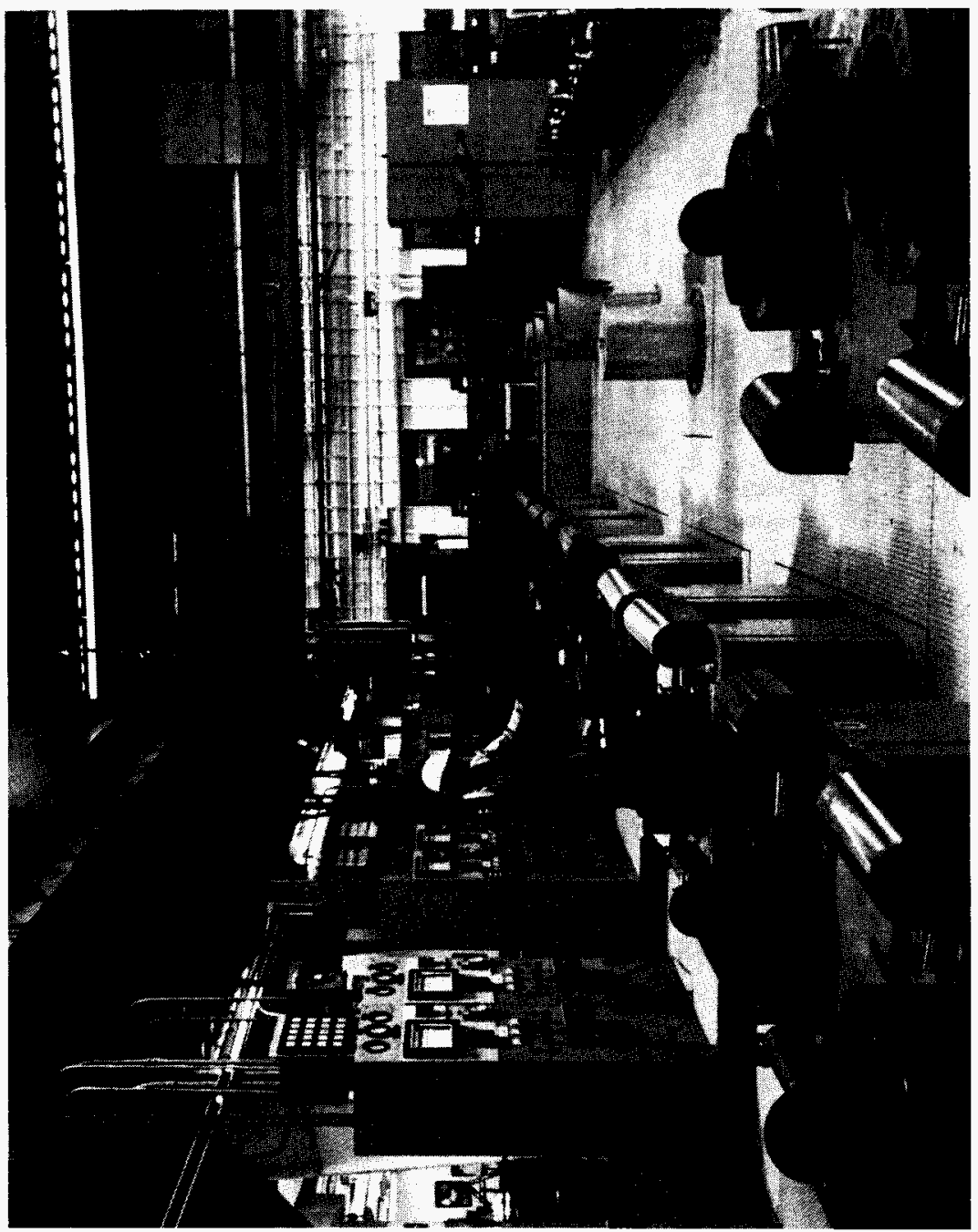


Photograph 1-4. N Reactor Fresh Fuel Being Loaded for Shipment to the Reactor in 333 Building, 1975.

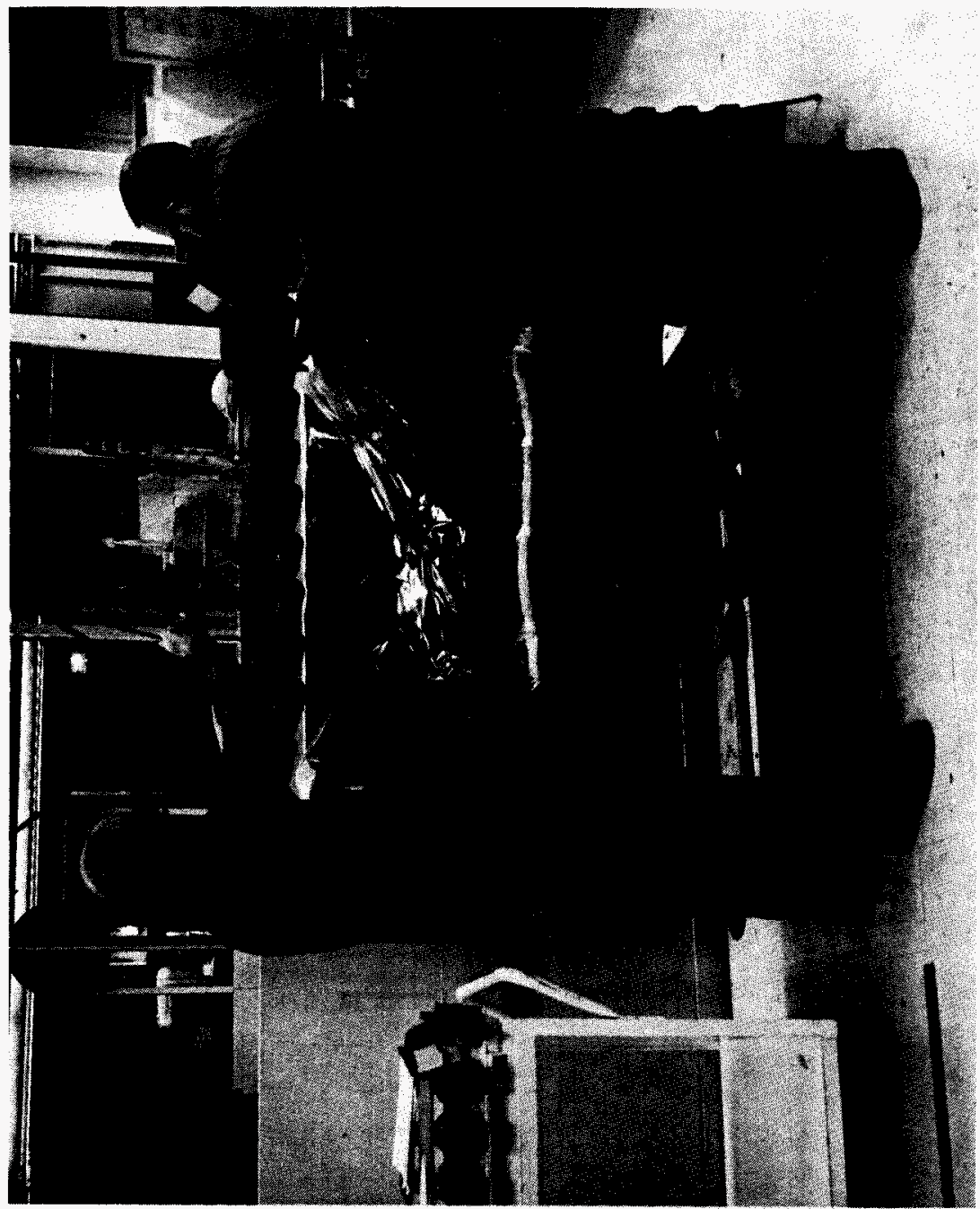


Photograph 1-5. 333 Building, New, Showing Tops of Autoclaves and Control Panel (3-27-61).

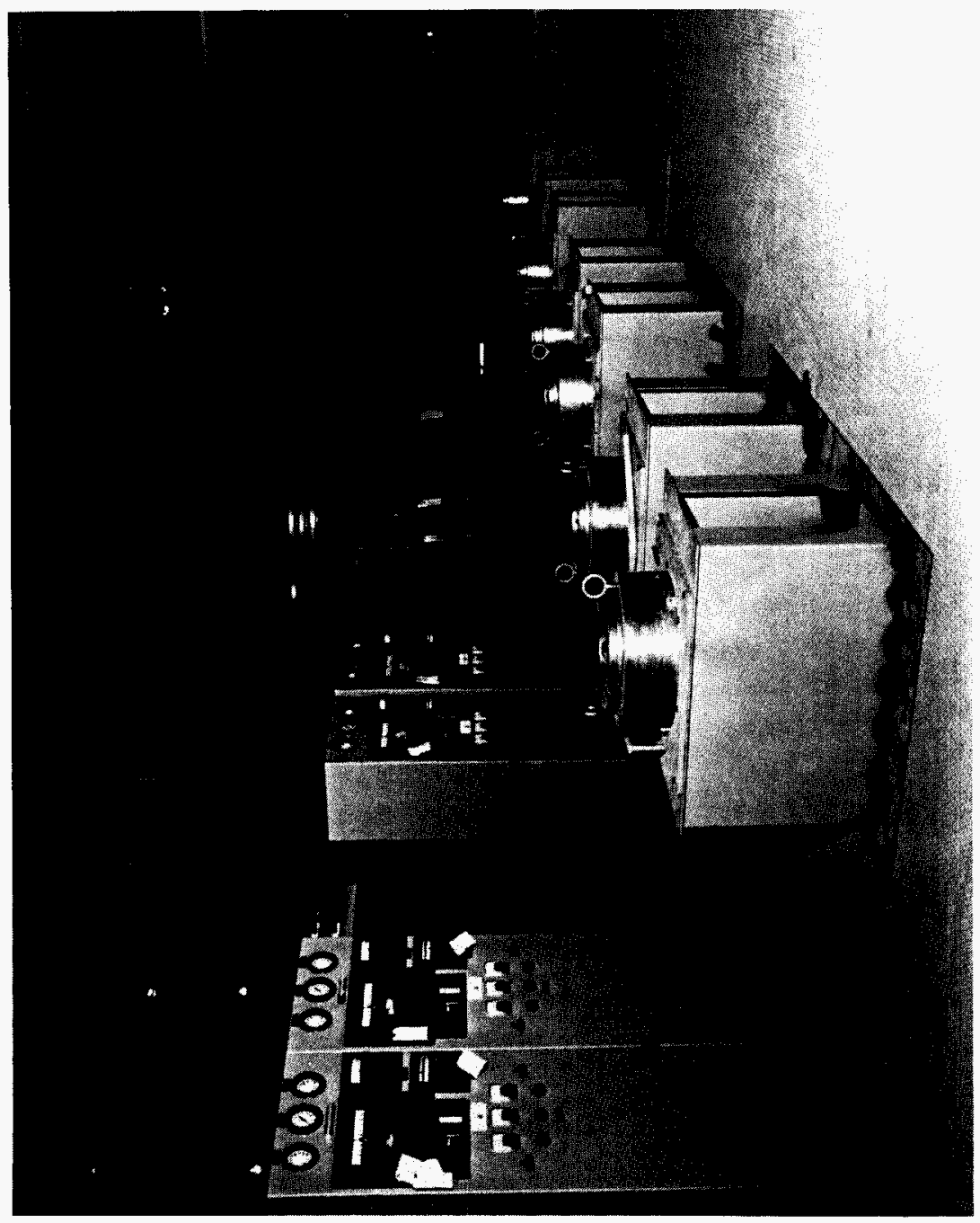


Photograph 1-6. 333 Building - Showing North Interior Wall of Chemical Bay - Under Construction (1-24-61).

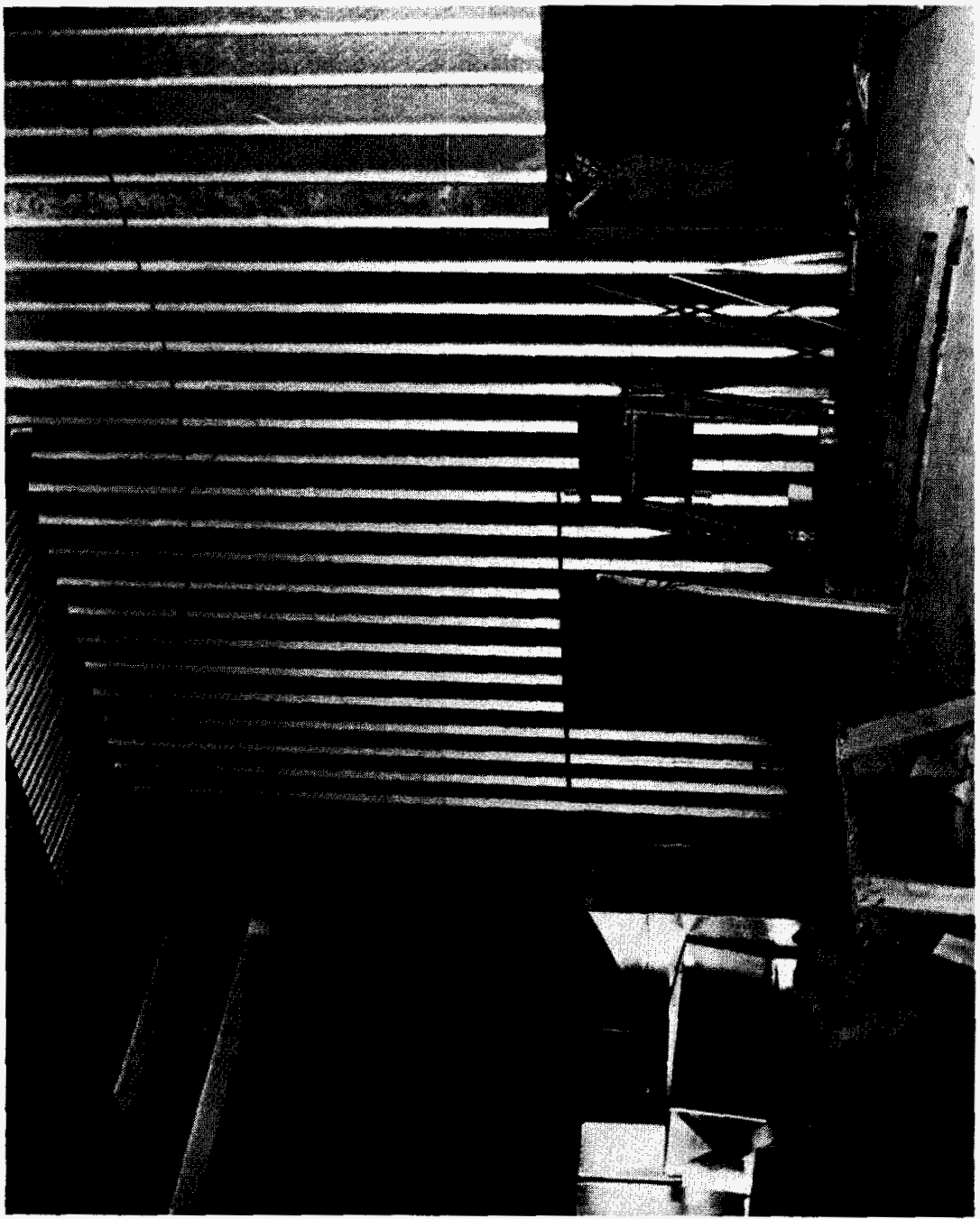


WHC-MR-0521, Rev. 0

This page intentionally left blank. 
WHC-MR-0521, Rev. O

\subsection{IRRADIATION PROCESSING AT THE HANFORD SITE}

\subsection{HANFORD'S SINGLE PASS REACTORS}

Nine plutonium production reactors, now closed and silent, cluster along a 14-mile (22.53 kilometers) stretch of the Hanford shoreline of the Columbia River. Eight of these reactors, all except the $\mathrm{N}$ Reactor, are known as "single-pass" reactors due to the oncethrough nature of their light water cooling systems. Known as "piles" in the 1940s, these machines drew cooling water from the river, and pumped it through a series of filtration, chemical treatment, and storage buildings and tanks. The water then was passed directly through long, horizontal tubes in the reactors, where the solid, Al-Si-jacketed uranium fuel rods underwent active neutron bombardment. From there, the water was pumped out the back of the piles, left for a brief time (30 minutes to 6 hours) in retention basins to allow for short-term radioactive decay, and then returned to the Columbia River. ${ }^{22}$

\subsubsection{Historic Significance of B-Reactor}

Hanford's original reactor, B, was the first such full-scale nuclear facility to operate in world history. Built by the Army Corps of Engineers and the DuPont Corporation in just 11 months between October 1.943 and September 1944, it now is listed on the National Register of Historic Places. B Reactor also has received special awards from the American Society of Mechanical Engineers and the American Society of Civil Engineers.

\subsubsection{Single-Pass Reactor Buildings}

The next seven reactors, D, F, H, DR, C, KE, and KW (in order of construction) were similar in most features. Built between 1943 and 1955, and shut down between 1964 and 1971, they had an average life span of just 21 years. The construction and general specifications of $B, D$ and $F$ Piles (the original three reactors built in World War II) were similar to those of most of Hanford's other single-pass reactors, although C, KE and KW were slightly larger and contained some special features. All of the piles rested on thick concrete foundations topped with cast iron blocks. The reactor buildings themselves were reinforced concrete structures shaped like tiered wedding cakes with no containment domes. They sat near the centers of five separate reactor areas of approximately 700 acres (283.28 ha) each.

The core of each reactor was a series of graphite blocks that fitted together. In the oldest six reactors, the cores each measured 28 feet ( 8.53 meters) from front to rear, 36 feet (10.97 meters) from side to side, and 36 feet (10.97 meters) from top to bottom. In the K-Reactors, the cores each were 33 feet (10.06 meters) from front to rear, 40 feet from side to side, and 40 feet $(12.19$ meters) from top to bottom. The graphite served as the "moderator" to slow and absorb extraneous neutrons from the basic nuclear chain reaction. Each stack was pierced front to rear by aluminum process channels that held the fuel elements. The first six Hanford reactors each contained 2,004 process channels, and the KE and KW Reactors each contained 3,220. The "lattice," or pattern of process channel configuration was a simple rectangle, with only the corners of the core bearing no 
penetrations. Each reactor's graphite core was surrounded by thick thermal and biological shields. The core and shields formed the reactor "block," and each block was enclosed in a welded steel box that functioned to confine a gas atmosphere. The atmosphere of the earliest reactors was composed of helium, an inert gas selected for its high heat removal capacity. ${ }^{23}$

At the front and rear of each process channel, a carbon steel exit and entry sleeve known as a "gunbarrel" penetrated the pile shields. The ends of each process tube flared into flanges to facilitate a close fit and interface against the gunbarrels. Asbestos gaskets lay between the flanges and the stainless steel nozzles that projected from the front and rear of each process tube. The nozzles connected to coiled lengths of aiuminum tubing known as "pigtails" (originally one-half inch (1.27 centimeters) in diameter but later larger), which in turn connected to stainless steel crossheaders. Devices known as "Parker fittings" "connected the pigtails to the crossheaders. The crossheaders [originally 39 sections of four-inch- (10.16-centimeter-) diameter pipesl served to break down the huge water supply entering the reactor building's valve pit via two 36 -inch-

(91.44-centimeters-) diameter headers, then two 36-inch ( 91.44 centimeters) risers. ${ }^{24}$

Test holes extended from the right side of each Hanford pile for the irradiation of experiments and special samples. Horizontal channels for control rods (HCRs) entered from the left side of each reactor, and vertical channels for safety rods (VSRs) entered from the top. The control and safety systems functioned simply to absorb neutrons, thus slowing and eventually stopping the controlled chain reaction of neutron exchange between the uranium fuel elements.

The early Hanford reactors also were equipped with various safety and control instruments that measured temperature, pressure, moisture, neutron flux ${ }^{b}$ and (radio)activity levels in the byproducts of the fission reaction. Because no one instrument had enough range to measure neutron flux all the way from shutdown (background) levels to the approximately 1,000,000,000,000 (1 trillion) times background levels experienced during operations, each reactor was fitted with sub-critical, mid-range and full power flux instrumentation. ${ }^{25}$

\subsubsection{Operation of the Single-Pass Reactors}

During actual operations, raw water was pumped from the Columbia River by pumphouses (known as 181 Buildings) located at and partially in the river. From there, water for the earliest reactors was pumped to the 182 Buildings, which routed much of the water to the 183 Buildings for chemical treatment, settling, flocculation and filtration. A small portion of the water proceeded directly from the 182 Buildings through large

\footnotetext{
- Parker fittings were a trademark product of Parker Intangibles, Inc., of Wilmington. $\mathrm{DE}$.

${ }^{b}$ Neutron flux is a measure of the level of neutron excitation, movement or activity during the fission process. Flux is measured in terms of the number of neutrons that strike one square centimeter in one second.
} 
concrete pipes to the Hanford's 200 Areas llocated 6 to 8 miles 19.66 to 12.87 kilometers) awayl for treatment and use there in chemical separations and other operations. From the 183 Buildings, Hanford's reactor process water was pumped to the 190 Buildings and stored in huge "clearwells" ready for pile use. In the 190 buildings, sodium dichromate was added to the water to prevent corrosion of pile process tubes. The 190 Buildings then supplied the reactors themselves as needed. Some of the earliest HEW reactor influent systems also contained 185 Buildings for dearation, and 186 Buildings for refrigeration of coolant water. However, these functions were found to be unnecessary and the 185 and 186 Buildings were diverted to other uses.

At HEW's earliest reactors, each process tube usually was charged with $32 \mathrm{U}$ fuel elements, along with a few dummy slugs in various configurations leither solid or perforated and hollow) at each end of the process channel. Many fuel configurations could be used to achieve various desired flux patterns across the reactor lattice.

\subsubsection{Change and Experimentation in Production Process}

The history of Hanford's single-pass reactor operations is one of constant change and experimentation. Many questions puzzled and intrigued early Hanford scientists. For example, they worried about the possibility of "slug failures," or the accidental penetration by cooling water of the aluminum jackets surrounding the fuel elements. They knew that such penetration would cause the uranium to swell, thus blocking the coolant flow within the process tube. This condition would necessitate tube removal and replacement, and could melt the fuel elements in that tube. Also, fuel ruptures would allow the escape of radioactive fission products in larger than average amounts. ${ }^{26}$

Another topic that intrigued the early operators of Hanford's reactors was that of temperature and neutron flux distribution. At first, "poisons" (neutron absorbing materials) were distributed in a uniform pattern throughout the reactor core during operation. This method of control produced a flux pattern that resembled a cosine (or bell) curve, front to rear within the pile. Such a curve meant that while uranium elements in the center of the reactor achieved maximum or optimum irradiation, many of the fuel elements located in the rest of the reactor achieved sub-optimal irradiation, due to lower neutron fiux. This situation not only was inefficient in terms of utilization of the uranium supply, it also contributed to temperature gradients that caused expansion in the graphite in the central portions of the pile.

Shortly after World War II, Hanford scientists tested several new poison patterns, with the goal of "flattening" the pronounced cosine curve, thus evening out the distribution of neutron activity and enlarging the area of maximum flux and temperature within the reactor. Quickly, they learned that many alterations in poison distribution (control rod positions) would achieve higher and lower temperatures and exposures in various reactor zones. They dubbed all of these manipulations "dimpling" the reactor. ${ }^{27}$ 


\subsubsection{Graphite Expansion Early Problem}

Of all the operational questions and issues that were pioneered in the Hanford reactors, almost none proved more compelling than those involving the graphite. Swelling (expansion) of the graphite, along with embrittlement, was a side-effect of irradiation. By late 1945, graphite expansion was causing the process tubes to bow, "binding" them too tightly with their fittings and other components, and straining the seals at the top and side corners of the reactor shields.

As a result, a Graphite Expansion Committee was formed at Hanford in early 1946..$^{28}$ Ultimately, concern over the graphite expansion problem and its intrinsic threat to pile "life" led to the decision on March 15, 1946, to shut down B Reactor. ${ }^{29}$ However, in mid-1947, convinced by positive developments in graphite study, site managers made the decision to restart the reactor the following year. ${ }^{30}$

By 1950 , further experiments had made it clear that the addition of carbon dioxide $\left(\mathrm{CO}_{2}\right)$ to the helium in reactor gas atmospheres could alleviate much of the graphite swelling problem. The $\mathrm{CO}_{2}$, because it had a lower heat removal capacity than the helium, allowed the carbon atoms in the graphite crystal, displaced by irradiation, to heat up, become active, and hence realign themselves. $\mathrm{By} 1954$, the $\mathrm{CO}_{2}$ additions were working so well the oldest reactors operated with a gas atmosphere composed of $40 \%$ helium and $60 \% \mathrm{CO}_{2}$, and tests were being planned to try even higher proportions of $\mathrm{CO}_{2}{ }^{31}$

\subsubsection{Increased Power Levels/Production}

Beyond even the graphite puzzle however, no early (and ongoing) operational issue was more important to the Hanford Works than that of increasing the power levels. $B$ Reactor, along with D, F, and DR, was designed to operate at 250 megawatts (MW thermal), while $\mathrm{H}$, built five years later, was designed for $400 \mathrm{MW}$. C Reactor, built during 1951-52, was designed for $650 \mathrm{MW}$, but the learning curve in pile operations took such a leap that the twin K Reactors (KE and KW) were built during 1953-55 designed for $1,800 \mathrm{MW}$ each. ${ }^{32}$

Questions concerning how to achieve higher power levels, with consequent increases in plutonium production, had intrigued Hanford scientists since World War 11 . In April 1949, an incremental test program that would take D-Reactor to $330 \mathrm{MW}$ was undertaken. By January 1950, this experiment was so successful that DR-Reactor was being operated at $400 \mathrm{MW} .^{33}$ With the acceleration of the Cold War, increased power levels in the Hanford reactors became even more important to perceived national defense needs. From the late 1940 s through the closure of the last single-pass reactor in 1971 , pile history at Hanford was dominated by constant efforts to achieve increased power levels.

By late 1956, under President Eisenhower's policy of "massive retaliation" and the boisterous challenges of Soviet Premier Kruschchev, the World War II power levels at the three oldest reactors had more than tripled, and stood at $800 \mathrm{MW}$. At that time, a thorough set of modifications designed to allow increased coolant flow was completed at these reactors. Similar modifications were made at the other single-pass reactors through 
the early 1960s, spurred by the threat of Soviet technical superiority as demonstrated by Sputnik. As a result of these changes, and of fuel and tube design improvements, power level increases in the World War II reactors reached the 2,200-2,400 MW range by the mid-1960s, just after the Cuban "missile crisis" had once again boosted American desired for a strong nuclear defense. The mid-1960s operating figures in the HW reactors were nearly 10 times the original design levels. At the KE and KW Reactors, final operating levels in 1970 and 1971 stood at approximately 4,100 MW each. ${ }^{34}$

Higher power levels themselves were easy to achieve, simply by adding enriched uranium fuel elements (those containing higher percentages of U-235). However, increased power levels presented many puzzling operational challenges in the effects they imposed on reactor systems and components. ${ }^{35}$ By mid-1951, Hanford scientists knew that the higher temperatures associated with increased power levels could produce substantially higher fuel jacketing and tube corrosion rates (and failure rates). ${ }^{36}$ However, their main concerns centered around how to deliver additional cooling water to, through, and out of the reactors. Such water would be needed to offset "boiling disease," the Hanford term for a situation wherein steam might form in a process tube. If this happened at higher power levels, greater water pressures would be needed to sweep the steam from the tube (and thus to prevent a localized meltdown). ${ }^{37}$

\subsubsection{Operating Challenges at Higher Power Levels}

By mid-1953, effluent removal piping at the oldest reactors, already operating at $20 \%$ to $50 \%$ above design capacity, was under intense study. ${ }^{38}$ At the same time, operators realized that the filtration capacity for intake water would have to be increased well beyond the original capacity of approximately 35,000 gallons (132 489.42 liters) per minute (gpm) per reactor. More important, however, was the need to increase the intake pumping capacity. ${ }^{39}$

In the meantime, as power levels crept upward in the oldest reactors during the late 1940 's and early 1950's, fuel element ruptures became a reality. The first rupture occurred at F Reactor in May 1948, and two others occurred later that year at B Reactor. ${ }^{40}$ The number of fuel element rupture incidents increased slowly during 1949 1950, but expanded dramatically in 1951 when Hanford Works experienced 115 fuel failures. ${ }^{41}$ This number continued to climb throughout the early 1950 s, bringing further focus to fuel fabrication improvement studies.

Along with fuel element failures, higher power levels and higher temperatures brought increasing levels of corrosion and failure of process tubes. By 1953, each Hanford reactor needed an average of 200 tube replacements per year. ${ }^{42}$ In order to reduce the ruinous corrosion, a special "Flow Laboratory" was built in late 1951 in a modified WWII refrigeration building. It functioned to study corrosion and heat transfer within process tube "mock-ups" (simulations). ${ }^{43}$

At the same time, the Hanford Works began an intense review of intake water treatments. ${ }^{44}$ Sodium dichromate, a key corrosion inhibitor that had been added to reactor water since World War II, was evaluated closely. Because sodium dichromate was known to have detrimental effects on the fish of the Columbia River, much 
experimentation with other corrosion blockers was undertaken. ${ }^{45}$ However, due to dramatic rises in tube and fuel element corrosion when the sodium dichromate was withdrawn, site scientists decided to continue using it. ${ }^{46}$

The drive to higher and higher power levels in Hanford's reactors throughout the late 1940's and mid-1950's was accompanied by the need for several changes to enhance operating safety. The "last ditch" safety system in the five oldest reactors was replaced with tiny, neutron-absorbing, nickel-plated carbon steel balls. These balis were poised in hoppers at the top of the piles, ready to pour in and tamp down the fission reaction if necessary. ${ }^{47}$ Physical braces and supports, and many additional instruments also were added. ${ }^{48}$

Other changes in reactor operations shortened the time required to perform routine operating chores. Since World War II, charge-discharge ("C-D") operations (loading and unloading the fuel elements from a reactor) were performed while a reactor was shut down. However, by 1950 experiments were underway to perform $C-D$ operations while a reactor was running. ${ }^{49}$ During the early and mid-1950s, such a system was tested successfully. It operated remotely, and worked by flushing fuel elements down the process tubes via high pressure water. ${ }^{50}$ Due to cost, this system were not installed at the oldest five reactors, but it was emplaced in the other, newer reactors.

Another change aimed at saving shutdown time in the Hanford reactors concerned "purging" or cleansing the process tubes. Minerals, elements and suspended solids in the Columbia River's water routinely built up a film on the process tube surfaces. This situation caused heat build-up within the reactors. ${ }^{51}$ Since World War II, operators had "purged" (scrubbed) the film from the tubes on a monthly basis, while the reactors were shut down. ${ }^{52}$ However, by the early 1950's the Hanford Works was trying to conduct "hot" purges -- so called because they occurred while the reactors were running. Such operations were very effective in removing reactor films, but greatly increased the levels of pollution entering the Columbia River. ${ }^{53}$

To help ameliorate the high levels of radioactivity, restrictions were placed on the frequency of purges that could be conducted during autumn periods of low river flow. Also, a series of experiments was initiated to find ways to protect the river. ${ }^{54}$

\subsubsection{Reactor Upgrades for Increased Production}

Beginning in 1954 and continuing into the early 1960s, a series of major modification projects designed to strengthen the reactor systems necessary to support power level increases were emplaced at the eight single-pass Hanford piles. Designated "Reactor Plant Modifications for Increased Production," these projects substantially increased intake pumping, filtration, and chemical treatment and storage capacities. ${ }^{55}$ Effluent systems likewise were strengthened and enlarged dramatically. ${ }^{56}$ Instrumentation with higher range capacity was emplaced. ${ }^{57}$ Electrical upgrades and many other miscellaneous changes were made within reactor systems. One such modification was the removal of aluminum liners (known as "thimbles" by Hanford workers) in some of the process channels, because higher operating temperatures would cause these liners to melt. ${ }^{58}$ 
Ironically, just as these projects were underway, significant changes in fuel elements and process tube designs and materials took place at the Hanford Works. These developments allowed dramatic increases in reactor power levels, once again straining the newly upgraded support systems. Much of the increase in power level was made possible by the use of the I\&E fuel elements, which were first tested on a production basis in $1958 .^{59}$ Other operating efficiencies that came quickly in the late 1950's and early 1960 's resulted from the gradual replacement of aluminum process tubes with tubes made of Zircaloy-2. Also, self-supported (projection, bumper or ribbed) fuel elements were developed at Hanford. Such fuel elements allowed greater passage of cooling water, again allowing higher power levels to be sought within a margin of safety. ${ }^{60}$

2.1.8.1 Maintenance and Safety Issues at Single-Pass Reactors. The higher power levels permitted by the development of internally and externally cooled fuel elements, ribbed fuel elements, and new process tubes, brought multiple operating challenges to the support systems of the Hanford reactors. Pumps and pipes developed destabilizing leaks, while electrical capacities proved inadequate. Much of the reactor instrumentation also was rendered obsolete. Even the graphite swelling problem increased, as the levels of neutron flux and bombardment rose exponentially. ${ }^{61}$ Safety reviews called for a mounting list of improvement projects. ${ }^{62}$

From that time forward, the story of the Hanford single-pass reactors became one of how to design and fund all of the support systems upgrades that were needed. One project that was accomplished at all of these reactors during 1960-62 was the construction of a large exhaust gas confinement system. It was comprised of a belowground filter building, duct work that routed gases from the reactor through these filters and then back into the exhaust stack, and sampling equipment. Another part of this project provided a rear face fog spray system for each reactor, and a front face fog spray system at C, KE and KW Reactors. ${ }^{63}$ Addlitionally, the Ball-3X systems at most of the reactors were upgraded in the early 1960s, as part of an overall "exposure reduction program" undertaken by Hanford's Irradiation Processing Department. ${ }^{64}$ Several instrumentation improvements and replacements also were approved for many of the reactors, based on safety and control considerations. ${ }^{65}$

\subsubsection{End of Single-Pass Operations}

In January 1964, President Lyndon Johnson announced that, due to a decreased need for special nuclear material (SNM), Hanford's reactors would be shut down in a phased sequence beginning in December $1964 .{ }^{66}$ At the same time, Columbia River pollution from reactor effluent was becoming an increasingly important factor in regional and national considerations. Hanford scientists, as well as health officials in Washington, Oregon and the U.S. Public Health Service became more and more concerned with the effects of reactor effluent in the huge river. By 1960, the total volume flow from the Hanford reactors had increased approximately ten-fold over that of the World War II period, shortening the practical retention time to only about 30 minutes and making diversion of unusual effluents to "cribs" (percolating areas dug into the earth) or other holding areas virtually impossible. Furthermore, the total amount of radioactivity reaching the Columbia River stood at nearly 14,000 curies per day. ${ }^{67}$ 
Within this effluent flow, the main isotopes of concern were phosphorus $32(P-32)$, zinc 65 ( $\mathrm{Zn}-65)$, chromium $51(\mathrm{Cr}-51)$, iron 59 (Fe-59), and arsenic 76 (As-76). It had been known since the late 1940s that these isotopes concentrated within aquatic plants and animals to vastly higher levels than were found in the river water itself. Multiple studies pointed to the fact that the Columbia's water could be at or below permissible levels for various radionuclides, and still present a hazard to consumers of river fish, ducks and other wildife. ${ }^{68}$

Throughout the late 1950 s and early 1960 s, virtually every aspect of the bioaquatic and potential downstream health consequences of reactor effluent was examined, including the effects of temperature, operating purges, various purge agents and filtration aids, fuel element ruptures, sodium dichromate, and the radionuclides themselves. ${ }^{69}$ Various solutions were proposed and tested. Salient among these was the concept of passing reactor effluent through beds of aluminum shavings, in order to entrap various radionuclides. ${ }^{70}$ Laboratory tests seemed promising, but a production-size bed installed in 1960 at the $D$ Reactor retention basin demonstrated so many shortcomings that the idea of decontamination of reactor effluent via aluminum test beds was effectively abandoned in $1961 .{ }^{71}$

Another concept that was explored thoroughly at Hanford was that of varying the intake water treatments. However, mixed results, combined with undesirable side effects, resulted in very little practical improvements. ${ }^{72}$ In the early 1960 s, an idea that had been explored in the 1950 s for reducing radionuclide releases to the Columbia River was revived. This "Inland Lake" concept proposed routing reactor effluent through trenches to artificial, inland lakes dug in the center of the site where the distance between land surface and the underground water table was significantly greater than it was near the reactor retention basins. Proponents of the idea pointed to the longer time period for radioactive decay and thermal cooling of effluent, before the wastes finally would reach the river. However, studies conducted in the 1950s had demonstrated undesirable effects, including the wind entrainment of radioactive mists that could spread contamination over wide areas extending even to offsite. Furthermore, problematic underground mounds in the water table, caused by disposal of low-level liquids wastes from chemical processing plants near the center of the site would be worsened by the addition of reactor effluent. ${ }^{73}$

As the reactor shutdowns began at Hanford in the mid-1960's, operators and scientists struggled to extend the viability of the remaining piles by developing environmentally acceptable means of effluent disposal. In the spring of 1967, with five single-pass reactors operating, a Hanford summary report on alternate methods of reactor effluent treatment and disposal listed several additional options. Conversion to recirculating cooling systems was listed as economically prohibitive, since it would involve providing 400,000 gallons (1 514164.75 liters) per minute of additional cooling (pumping) capacity per reactor, with all attendant piping modifications. Other related equipment also would be needed for each reactor, for a total conversion cost of $\$ 32$ million per reactor. Other potential solutions also were expensive and posed awkward siting problems between the reactors and the Columbia River. Still other, less expensive proposals each came with physical or acceptability barriers. ${ }^{74}$ The eight single pass reactors at the Hanford Site all closed permanently between December 1964 and January 1971 . 


\subsection{N REACTOR OPERATIONS}

The Hanford Site's ninth defense production facility, N Reactor, operated from early 1964 to December 1986. Like Hanford's single-pass reactors, N Reactor was tied in umbilical fashion to the Columbia River, and it was light water cooled, graphite moderated, and fueled with bored metal uranium. Also, none of the defense production reactors at the Hanford Site were equipped with containment domes. Nevertheless, there were major differences between $N$ Reactor and the older Hanford piles. N Reactor recirculated its primary coolant water, instead of returning it to the river, thus releasing significantly less radioactive effluent (waste water) on an everyday basis. Additionally, the light water coolant circulated under pressure, allowing for much higher operating temperatures, and the water was demineralized so that less film was deposited inside the process channels.

Another major difference between N Reactor and the older Hanford piles was that $N$ Reactor had a negative-void coefficient design, while the single pass reactors had a positive-void coefficient design. The negative-void factor was a crucial safety feature because it meant that when a steam bubble or void developed in a process tube, the effect tended to shut down $N$ Reactor. This factor prevailed because, at $N$ Reactor, there was a low ratio of graphite moderator to $U$ fuel. The cooling water provided a significant portion of the moderating effect. Thus, loss of coolant had the effect of reducing reactivity. In the single pass reactors, a steam bubble or void tended to increases the neutron flux logarithmically, thus enhancing the chances for a nuclear accident. Lastly, in 1966, the steam generated from the heat of the nuclear chain reaction was captured at $N$ Reactor to produce electricity for the domestic power needs of the Pacific Northwest. Today, $N$ Reactor remains as the only U.S. defense reactor that served a "dual purpose." 75 .

\subsection{1 $105 \mathrm{~N}$ Building and Reactor}

The 105-N (N Reactor) Building was a reinforced concrete structure sitting atop a thick slab of reinforced concrete. The reactor core itself was 39 feet $(11.89$ meters), 5 inches (12.70 centimeters) high, 33 feet (10.06 meters) wide, and 33 feet (10.06 meters), 4.5 inches (11.43 centimeters) tall. It consisted of 1,800 tons of nuclear grade graphite blocks notched, interlaid and pierced by 1.004 process channels. The lattice was arranged in a rectangle 32 feet ( 9.75 meters) high by 34 feet (10.36 meters) wide, with 21 channels omitted from each corner. Eighty seven HCRs entered the $N$ Reactor core, 41 from the left side and 46 from the right side. One hundred and eight vertical safety channels existed to receive ceramic " $3 X$ " balls to shut down the reactor in case of need. A small number of other channels pierced the core to hold experiments, and to position traverses to measure graphite distortion over time, graphite temperature, and flux. Graphite bowing over time was both expected and feared by the designers of $N$ Reactor. The original reactor manual stated that "there is as yet no determination of the maximum extent to which contraction of nuclear graphite can be induced by irradiation." An 8.3-inch (21.08 centimeters) depression at the top center of the graphite moderator was chosen as the original design basis, corresponding to about a three percent contraction, while 12 inches (30.48 centimeters) was "estimated to be tolerable for the reactor as built." The design lifetime of the reactor was 25 years. ${ }^{76}$ 
The N Reactor core was surrounded special layers of reflector graphite, then by water cooled thermal shields constructed of boron steel and cast iron, and then surrounded again by a primary shield of high density concrete. Helium gas formed the pile atmosphere. A fog spray system at both the front and rear reactor faces was provided for contamination control and cooling in case of a loss of contaminated steam from the core. The water influent system began at the $181-\mathrm{N}$ River Pump House, proceeded to the 182-N High Lift Pump House where raw river water was treated and where demineralized and deoxygenated water was injected into the makeup and cooling water, the 183-N flocculation and filter plant, and to the 183-NA Pump House that sent coolant water into the reactor. Extra supplies of treated water were held in the 183-NB clearwell. $N$ Reactor's primary coolant system used from 100 to 1,500 gallons $(378.54$ to 5678.12 liters) per minute of fresh, treated water, a vast decrease from the $3.5,000$ to 105,000 gallons (132 489.42 to 397468.25 liters) per minute consumed by Hanford's single pass reactors. ${ }^{77}$

\subsubsection{N Reactor Operating Changes and Challenges}

Over its years of operation, many changes took place at N Reactor. From 1965-67, a "co-product" demonstration campaign took place, in which tritium was produced in the reactor from special lithium aluminate fuel elements. Beginning in 1966, N Reactor steam for electrical production was harnessed at the Hanford Generation Plant (HGP) constructed just west of the pile by the Washington Public Power Supply System (WPPSS). In 1971. $N$ Reactor was ordered closed due to a diminished national need for defense plutonium production. An agreement was reached to keep the reactor running primarily for electrical production. During the 1970 s, a time when the entire Hanford Site undertook modifications to achieve more desirable interfaces with the environment, a number of upgrades to N Reactor's waste treatment systems were emplaced. Trenches were dug to receive reactor effluent, thus allowing a longer percolation time through the soils just inland from the reactor, for radioactive decay to occur before effluents reached the Columbia River. Monitoring instrumentation for waste products was added, secondary and shield coolant loops were converted from single-pass to recirculating systems, and a special containment tank was constructed to hold the pile purge effluent for transfer to Hanford's high level waste storage tanks. Release of this purge material to the Columbia River was discontinued. ${ }^{78}$

Beginning in the early 1980s, a large defense build-up was ordered by President Ronald Reagan. At the same time, $\mathrm{N}$ Reactor arrived at 20 years old and began to experience system failures of many types. One fundamental problem was the distortion of the graphite stack, where built-in slip joints could not accommodate all of the local distortion, some block cleavage, and actual separation of blocks that had occurred within the central core. Such distortions produced "significant changing problems" by 1982 . Additionally, the 1982 summer outage revealed center transverse contraction resulting in a total sag of about three inches, and tube elongation to the extent that many connector clearances were rated as "minimal." As $N$ Reactor struggled to remain a crucial piece of America's defense arsenal, many system upgrades were undertaken. In the 189/190-D Thermal Hydraulics Laboratory, a complete mock-up of $\mathrm{N}$ Reactor's core, in it's actual distorted and curved condition, was built, in order to study remediation concepts. An N Reactor Loop Components Test Facility, a high temperature, pressurized, 
recirculating demineralized water test loop also was constructed to model and evaluate leaks in the primary flush lines of the core, various valves, and alternative ideas for operations. Another model was built to test inspection and removal equipment for the graphite cooling tubes, and to demonstrate a process tube drying system. In April 1986, an accident at the Chernobyl nuclear plant in Soviet Russia brought about a stand down for safety evaluations at $N$ Reactor. The reactor never re-opened. It was ordered to cold standby by the DOE in February 1988, and a large D\&D project leading to final disposition began in $1994 .^{79}$ 
Photograph 2-1. Charging "Face" of B Reactor.

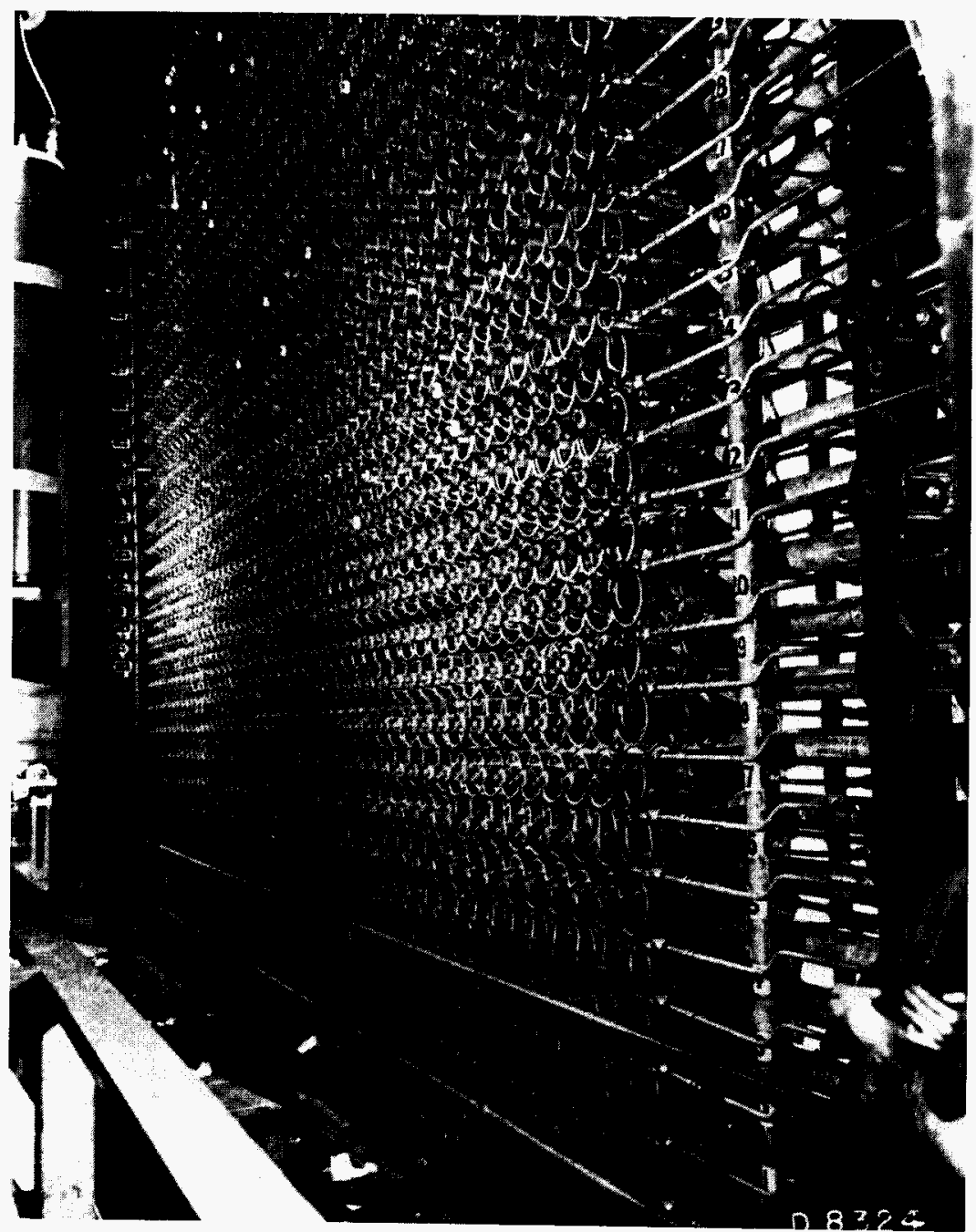


Photograph 2-2. Graphite Layup for C Reactor Core, 4-21-52.

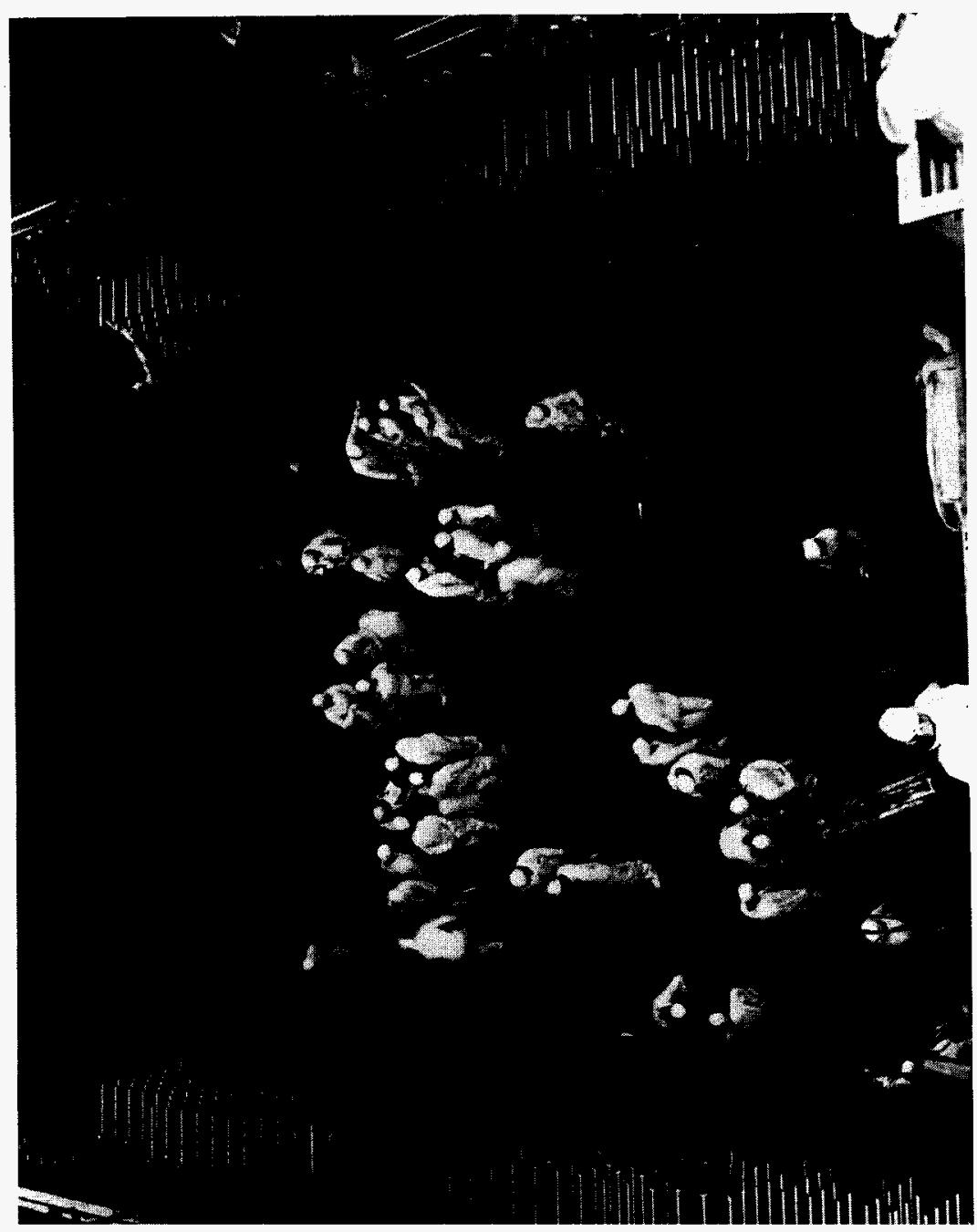


WHC-MR-0521, Rev. 0

Photograph 2-3. C Reactor, Mid-1950s.

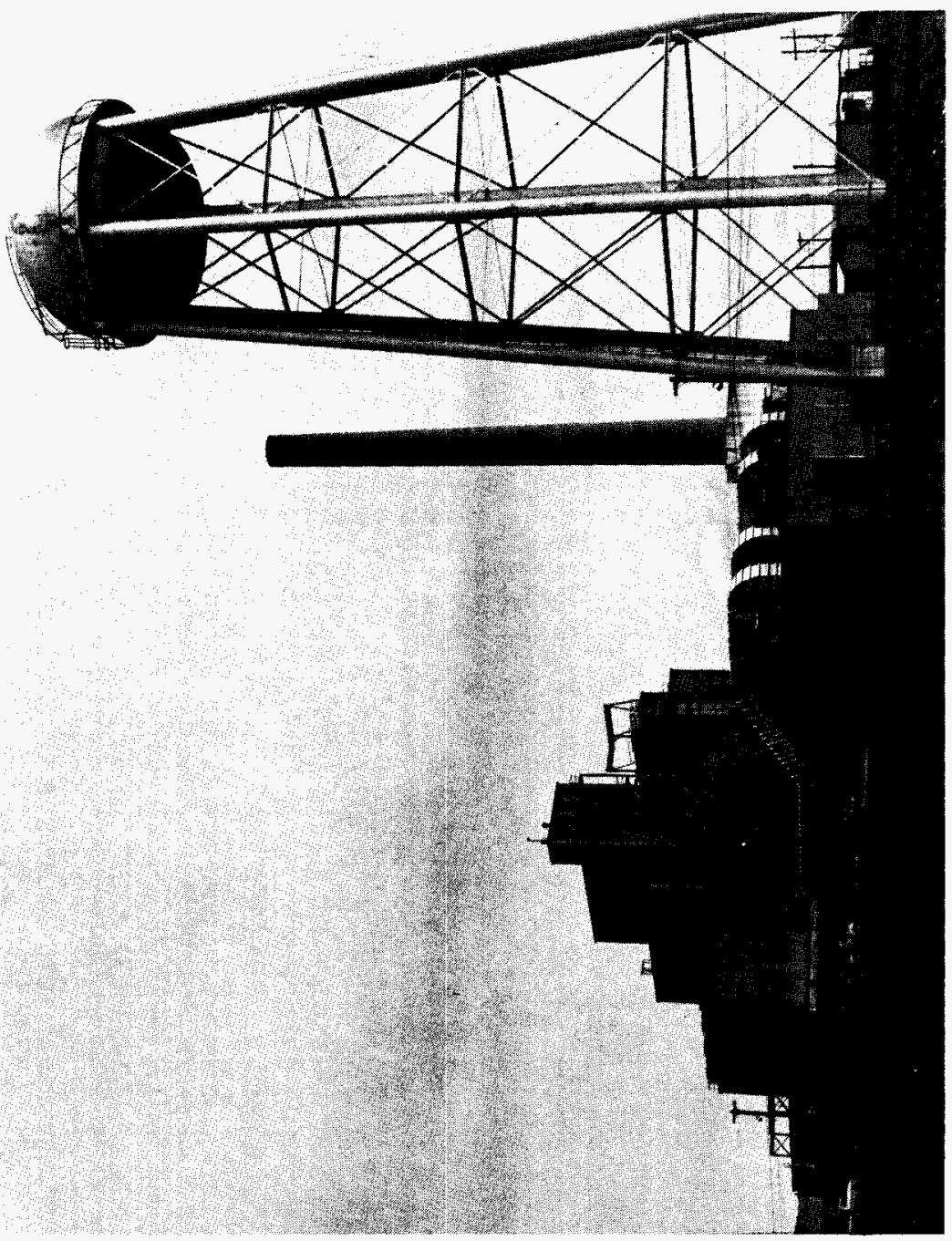

2. 14 
Photograph 2-4. Front Face Area of KE Reactor, Showing Fresh

Fuel in Boxes Ready for Charging into the Reactor, 1960 s.

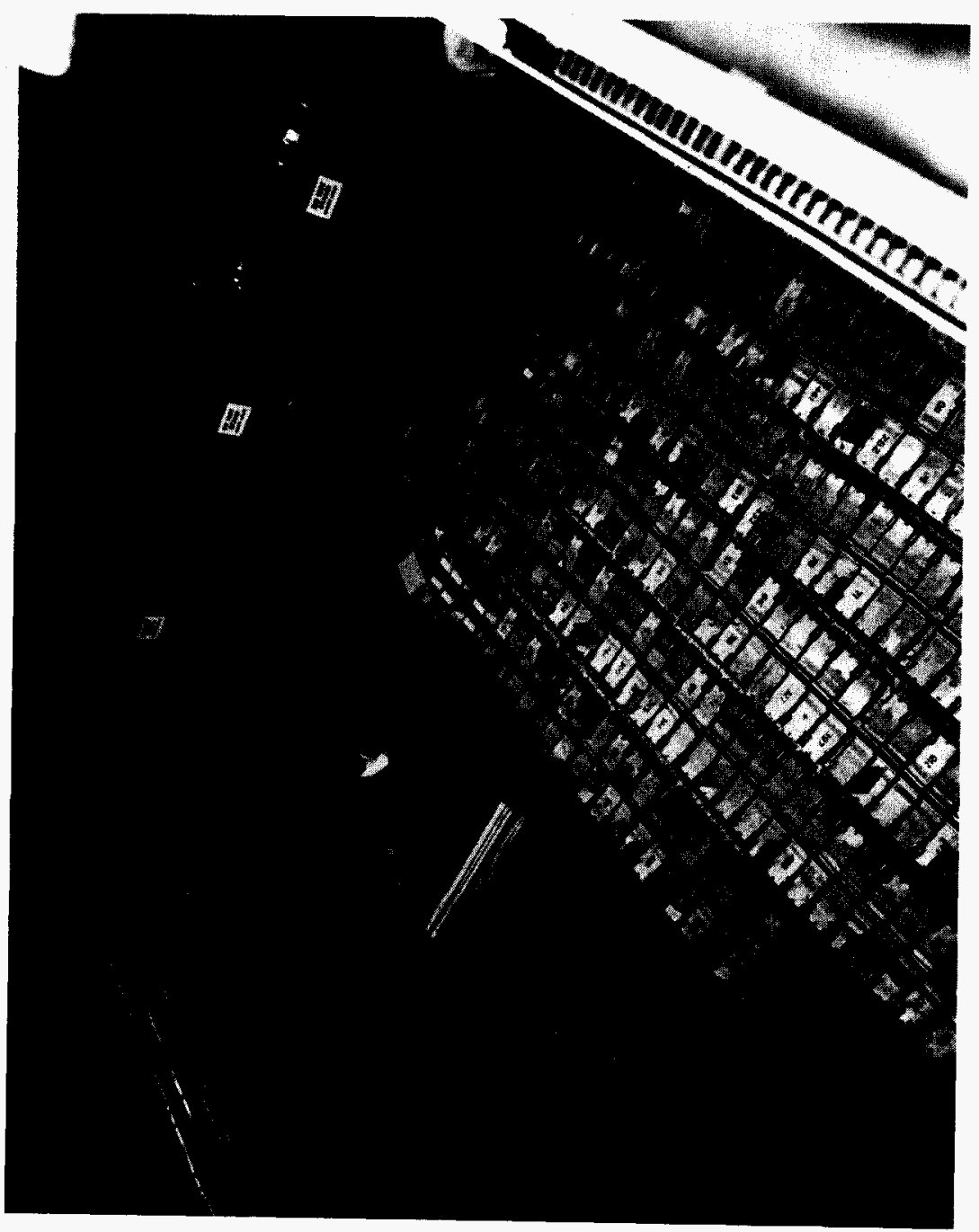


Photograph 2-5. K Reactor Workers Check Process Tubes, 1960 s.

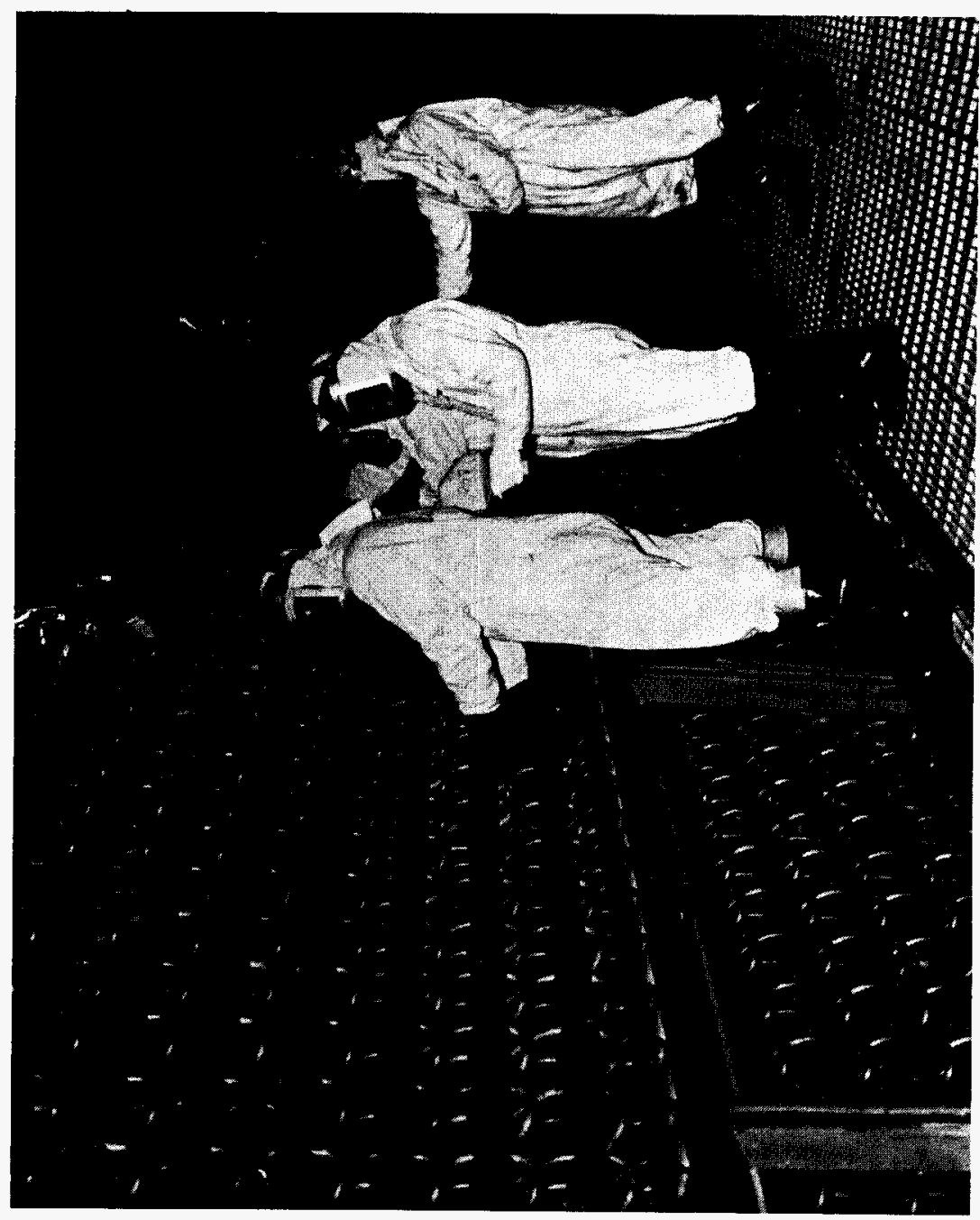


WHC-MR-0521, Rev. 0

Photograph 2-6. N Reactor Front Charging Face, 1960 s.

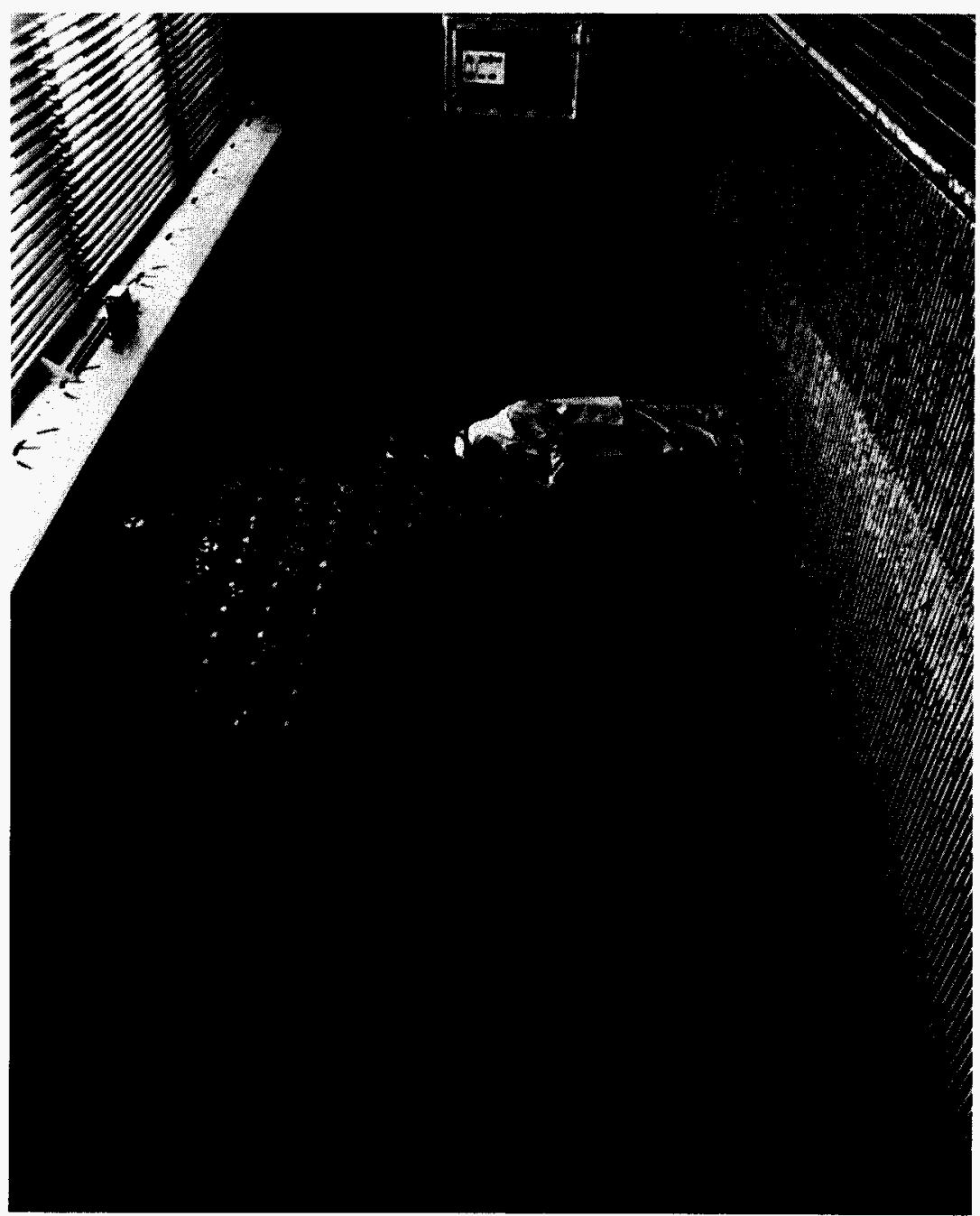


Photograph 2-7. N Reactor and Support Buildings, 1970 s.

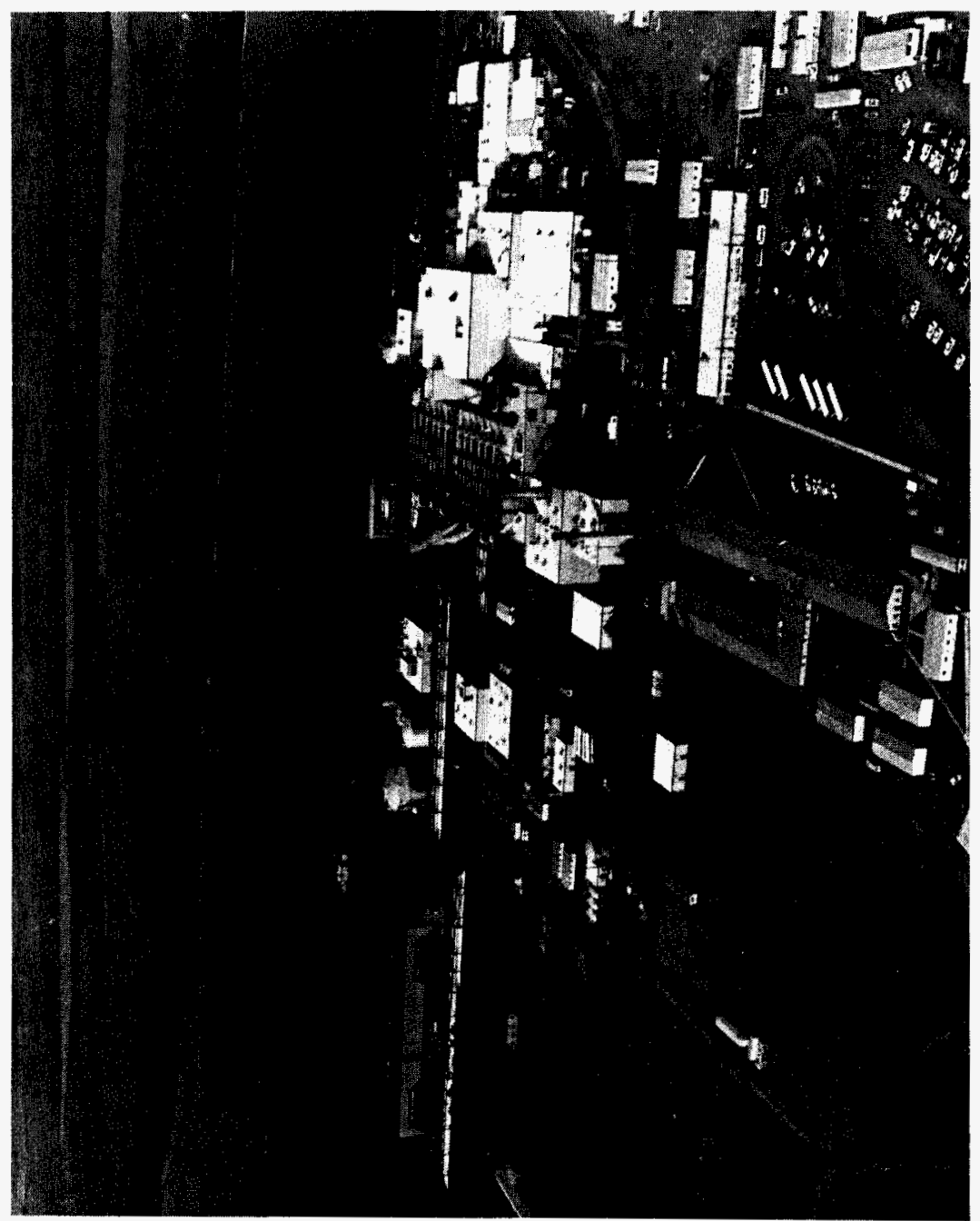


WHC-MR-0521, Rev. O

\subsection{SPENT FUEL HANDLING AT THE HANFORD SITE}

\subsection{ORIGINAL LAG STORAGE PRACTICES}

After irradiation in a reactor, nuclear fuel is known as "spent fuel." In defense production at the Hanford Site, this fuel has always placed under water, allowed to undergo a period of radioactive decay, and then chemically dissolved and "re-processed" to separate the Pu product from associated fission products and other elements. In HEW jargon, the solid $U$ fuel elements were known as "lags" as soon as they became spent fuel. B-Reactor and HEW's other earliest reactors were constructed with spent fuel basins just below the rear faces. The fuel was literally pushed out the rear face of each reactor by charging fresh fuel into the front. Spent fuel basins at the earliest Hanford reactors each were 81 feet ( 24.69 meters) by 68 feet $(20.73$ meters), and were divided into two sections each. The basins were 20 feet $(6.10 \mathrm{~m})$ deep, although the water was maintained at about 16 feet $(4.88 \mathrm{~m})$ deep. Each basin was served by submerged buckets that were suspended from a monorail via 25-foot (7.62-meter) yokes. Long rakes and tongs were used to load each bucket with one-half ton of fuel elements.

Viewing of the discharge area was accomplished with two main periscopes, located on the ceiling of the discharge area and on the wall opposite the rear face of the pile. Additionally, the latter location contained a "Fly-eye" viewer that consisted of four wideangle lenses. A shielded cab, which could be attached to the 50,000-pound (22 679.62 kilograms), 8 to 10 feet (2.44 to 3.05 meters) wide "D" elevator, also had its own periscope. One last periscope was located in the labyrinth that led to the discharge area balconies, but its view often was blocked by the "D" elevator (which had to be raised to the top of the reactor's rear face during discharge operations). Thermocouples were placed at the inlet and outlet of the storage basin, and water temperature levels as indicators of radiation intensity were monitored carefully.

The earliest spent fuel handling practice at the Hanford Site was to keep the lags in the basins at the reactor rear faces for a very short period of time (several hours to one day). The irradiated fuel rods then were loaded into shielded rail cask cars and taken to the 200-North Area for storage in the 212 Lag Storage Buildings. Within any one of these three buildings, the rods were stored for periods of time ranging from a few weeks up to perhaps as long as $\mathbf{5 0}$ days, to allow for isotope decay, before they were taken to either T-Plant or B-Plant for chemical separation. ${ }^{80}$

\subsection{LAG STORAGE BUILDINGS CLOSE}

As the needs of the Cold War rapidly increased Pu-239 production at Hanford, difficulties developed with the 212 Buildings. By 1950, Site planners realized that additional capacity for lag storage was needed. One key factor was the AEC's decision to store spent fuel from 90-125 days before re-processing, in order to reduce the emissions of iodine $131(1-131)$ and other gaseous fission products into the regional environs. Other crucial factors included the increased amounts of fuel being produced and handled once the $H$ and DR reactors came on line in 1949 and 1950 respectively, and the anticipation that various forms of E-metal would be tried in order to push production even higher. In 
WHC-MR-0521, Rev. 0

1951, with C-Reactor under construction, as well as the desire to save the transportation costs to and from the 212 Buildings and to reduce radiation exposure to workers from fuel transfers, the 212 Buildings closed. From that time forward, spent fuel at Hanford was stored only in the fuel basins at the rear faces of the reactors. ${ }^{81}$

The reactor fuel storage basins, as had the 212 Buildings, operated within certain fundamental parameters. All cooling was accomplished using either once-through or feedand-bleed principles. Filtered water was routinely added to the basins and water was discharged either via overflow weirs or floor drains. The discharged water was routed to cribs for soil filtration. As a result of this routine water addition, the fuel storage basins at Hanford were relatively clean radiologically. Additionally, fuel was always stored in open containers. This facilitated heat removal after discharge from the reactor. Corrosion products were not an issue because following a relatively short storage time, fuel was processed. The fuel storage basins at the KE and $\mathrm{KW}$ reactors operated in the same manner, although they were larger. At these piles, the rectangular, reinforced concrete basins each were 125 feet ( 38.10 meters) long, 67 feet (20.42 meters) wide, 21 feet (6.40 meters) deep, and were divided into three sections. By the early 1960, lag storage time at HW had increased to an average of $200-250$ days. ${ }^{82}$

\subsection{CLOSURE/RE-OPENING OF FUEL STORAGE BASINS}

As each HW reactor closed between 1964 and 1970, its spent fuel basin likewise closed. In some cases, fuel storage basins at a given reactor would remain open a number of months after the pile itself had shut down, in order to accommodate fuel from another reactor. However, all lag storage basins except for the $\mathrm{N}$ Reactor basin closed by 1971. In 1972, the last radiochemical processing plant at the Hanford Site, the PUREX (plutonium uranium extraction) Plant entered a long shutdown period (although it later re opened). The N Reactor, because of its dual-purpose design, was kept operational to support Pacific Northwest electrical power needs. N Reactor was operated in this mode throughout the decade, and continued to produce spent fuel. The $N$ Reactor fuel storage basin was not sized to support the resultant fuel inventories. As a result, the decision was made to use the $K$ Reactor spent fuel basins for additional storage space for $N$ Reactor lags.

The K East basin was the first to be modified to store $N$ Reactor fuel. It received only superficial cleaning, and the bare concrete walls of the basin were left uncoated. All drains and overflow weirs were blocked off and a water recirculation system was installed. The recirculation system consisted of two pumps, two underwater cartridge filters for particulate removal, and two water-to-water heat exchangers for basin cooling. Storage racks were installed on the basin floor to support single tier storage of $N$ Reactor fuel. Filtered water was used to supply the basin water make-up needs. A barrier was installed across the entrance to the North Loadout Pit to isolate it from the basin proper. The actual construction activities were completed and the facility began accepting $N$ Reactor fuel in 1975. N Reactor fuel was shipped and stored in open containers. The containers (canisters) were specifically designed for this purpose. These canisters remained unchanged from the design used to support earlier N Reactor operational needs. 
The fuel inventory quickly grew in the $K$ East basin and along with it, radiological problems. With the basin sealed and with no ability to add clean water and discharge contaminated water, fuel corrosion products were captive in the facility. Radioactive contamination and radiation exposure levels increased. Steps were taken to mitigate this situation included the addition of a skimmer system along with a sand filter, and later, an ion exchange system. As the PUREX Plant remained closed and $\mathrm{N}$ Reactor continued to operate, plans were initiated to modify the $\mathrm{K}$ West basin to accommodate the extra fuel. ${ }^{\text {в3 }}$

The $K$ West modification was designed to prevent a recurrence of the $K$ East Basin experience. The $\mathrm{K}$ West Basin was drained and the walls and floor were cleaned and sealed with an epoxy material. The drains and overflow weirs were blocked off. All of the basin clean-up systems in operation at $\mathrm{K}$ East were installed in the $\mathrm{K}$ West Basin. These included a basin recirculation system with cartridge filters and heat exchangers, a skimmer system with a sand filter, and an ion exchange system. The decision was also made to fill the basin and maintain water level using demineralized water. A lid design was developed for the existing fuel storage canisters which allowed them to be closed. The design allowed the canisters to vent if there was any gas generation. Fuel shipments to the $\mathrm{K}$ West Basin began in 1981, with all fuel shipped to and stored in closed canisters. ${ }^{84}$

In 1983, when the PUREX plant was getting ready to resume reprocessing of spent fuel to recover plutonium and uranium, the fuel in the $K$ East basin was sorted to separate the weapons-related fuel from that used to generate electricity. The fuel was dumped from the canisters, sorted and placed back in the open canisters. A proposal to place the $K$ East fuel in sealed canisters, like those used in $K$ West, was rejected. Today, the $K$ East Basin holds the nation's largest single concentration of stored spent fuel. The existing fuel inventories include $3600+$ open canisters of spent fuel stored in the $K$ East Basin and $3800+$ closed canisters of spent fuel stored in the $K$ West Basin. This inventory totals -2100 MTUs. 
Photograph 3-1. Construction of 212-N Lag Storage Building, 4-19-44.

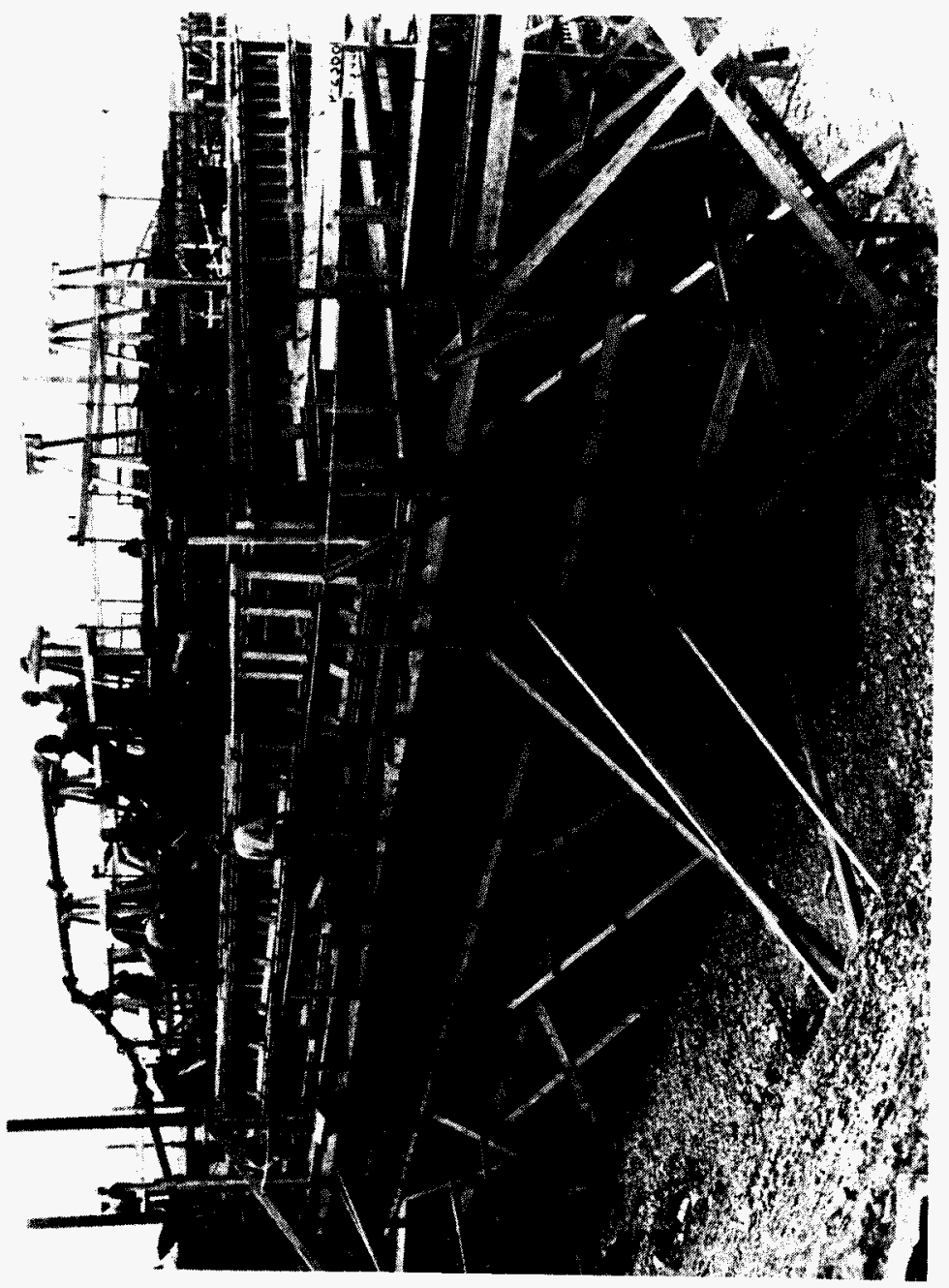


WHC-MR-0521, Rev. O

Photograph 3-2. N-Reactor Rear Face Spent Fuel Basin, 1980s, Showing Fuel at Bottom.

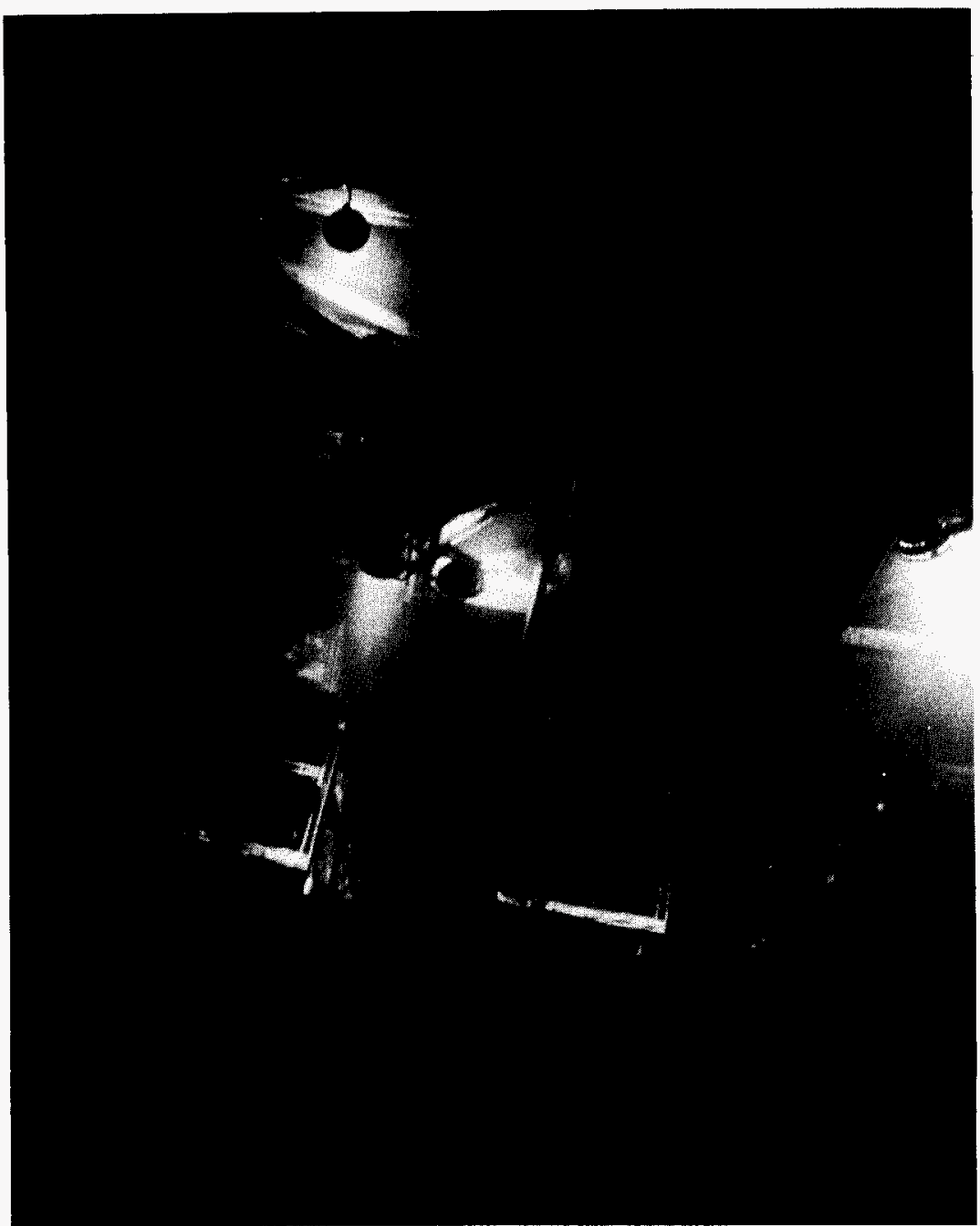


Photograph 3-3. N Reactor Spent Fuel Basin.

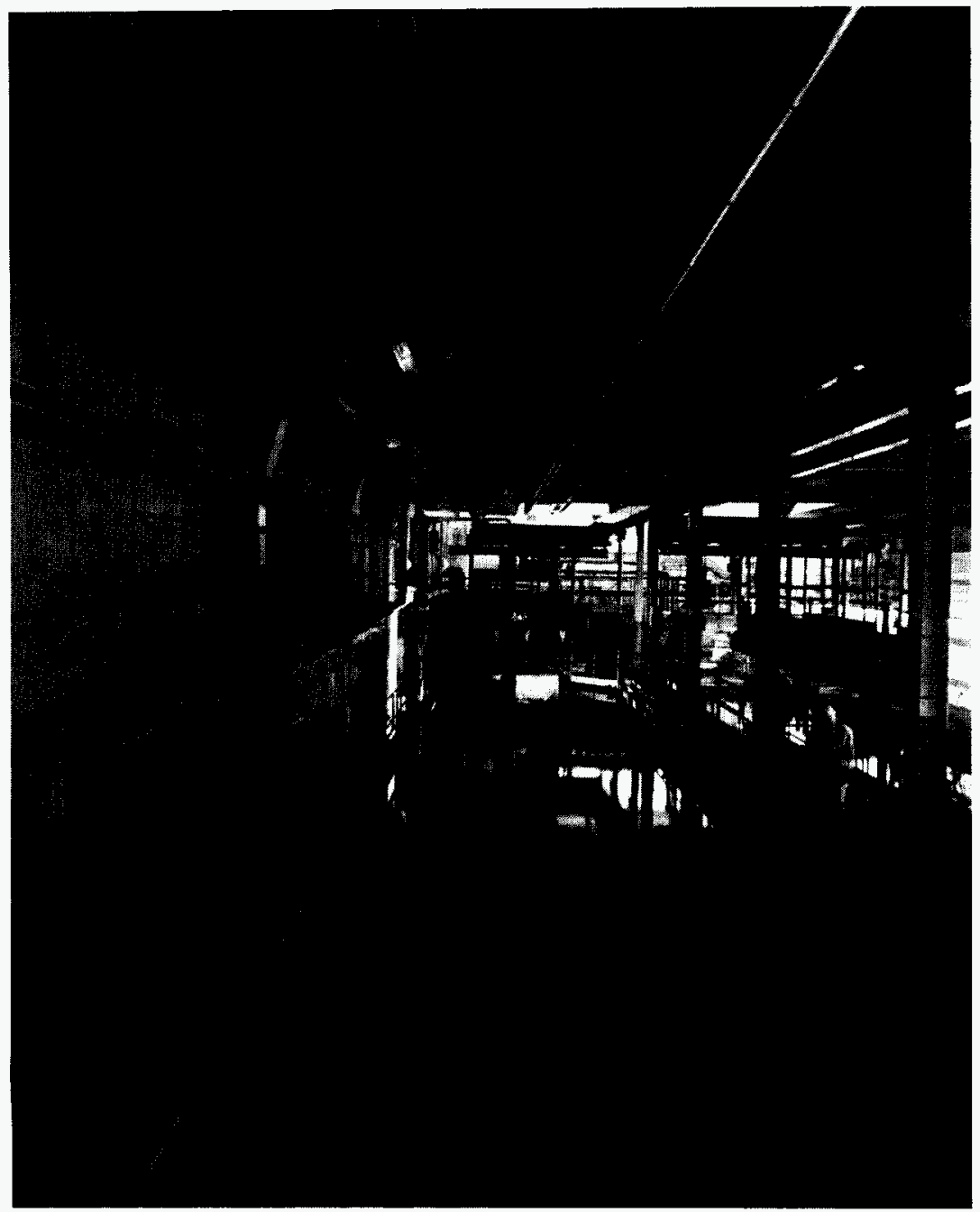




\subsection{RADIOCHEMICAL SEPARATIONS PROCESSING AT THE HANFORD SITE}

\subsection{THE BISMUTH-PHOSPHATE PROCESS}

\subsubsection{Start-up of Radiochemical Processing at HEW}

The earliest radiochemical processing operations at the Hanford Engineer Works using "hot" (irradiated uranium) feed began at the 221-T Cell Building, also known as T-Plant or T-Canyon, on December 26, 1944. This event was historic because T-Plant was the first full-size radiochemical processing plant in the world. The only previous radiochemical processing of irradiated uranium fuel elements had been done on an experimental scale at a facility known as the Clinton Semi-Works (or SMX), located at the Clinton Engineer Works in Oak Ridge, TN. ${ }^{85}$

\subsubsection{T, B, and U Process Groups}

The original separations process used at HEW was the bismuth-phosphate (BiPO4) process. It was based on the principle that bismuth phosphate is similar in crystal structure to plutonium phosphate. The entire operation was a batch, precipitation process that achieved separation by varying the valent state of plutonium 239 ( $\mathrm{Pu}-239)$, and then by repeatedly dissolving and centrifuging plutonium-bearing solutions. The steps of the bismuth-phosphate process were carried out first in T-Plant, then in the 224-T Bulk Reduction Building, and then in the 231-Z Isolation Building. A second and third set of facilities for both the first and second phases of the BiPO4 process also were built at HEW, but the final steps always took place in the 231-Z Building. The second set of facilities was known as the B Process Group, and consisted of the 221-B (B-Plant) and 224-B Buildings and their associated support structures. B-Plant began processing irradiated $U$ at Hanford on April 13,1945. The third set of facilities was known as the $U$ Process Group, and consisted of the 221-I (U-Plant) and 224-U Buildings and their associated support facilities. The $U$ Process Group never handled irradiated uranium, but served as a training facility until another use for the buildings was developed in $1952 .^{86}$

\subsubsection{Original Separations Buildings}

The 221-T Cell Building originally was 85 feet (25.91 meters) wide by 875.5 feet (266.85 meters) long by 102 feet high. It was a dense, thick, reinforced concrete, rectangular mass, approximately one-quarter below grade, with no windows. At the time that T-Plant was built, its design and construction was described by the DuPont Corporation builders as "extremely unusual...due to process requirements. In other words, once the equipment in any of the cells is placed in operation, it will not be possible to approach it for maintenance or to manually remove or fit up piping." Remote operational requirements, as well as radiation shielding requirements, resulted in the $221-\mathrm{T}$ Building being unique, and a first-of-a-kind structure in the world, when it was built. The 
221-B Building was virtually identical to T-Plant, except that it had 65 feet (19.81 meters) less length and did not contain a special head-end testing laboratory that was included in T-Plant.

The foundation of each canyon building structure was a reinforced concrete pad varying from six to eight feet ( 1.83 to 2.44 meters) in thickness with a spread footing. Outside building walls were likewise reinforced concrete three to five feet 10.91 to 1.52 meters) thick. The barricade wall between the cells and canyon and the galleries was seven feet (2.13 meters) thick. Each building had a suspended flat concrete roof varying from three to four teet ( 0.91 to 1.22 meters) in thickness. Construction joints were provided between each building section and expansion joints at frequent intervals. The inside surfaces of the cells and pipe trench, removable cover blocks, the deck floor level in each canyon, and each second floor control gallery were painted with "Amercoat," an epoxy-based contamination fixant sealant, to reduce the porosity of the concrete surfaces.

Each 221 Building structure was separated into two main portions - Galleries and Canyon, with the inside of the building being divided into 22 sections (for T-Plant) and 20 sections (for B-Plant). Each section encompassed two cells. Sections were 40 feet (12.19 meters) long with the exception of Sections 1, 2, and 20, which were 44 feet (13.41 meters), 43 feet (13.11 meters), and 43.5 feet (13.26 meters) respectively.

Inside the head-end of T-Plant, were two developmental equipment cells, A and B, having the same length as cells $1,2,3$, and 4 (a total of 65 feet (19.81 meters) in length]. The essential difference between this testing laboratory and a standard T-Plant section was that each testing laboratory cell contained the equipment corresponding to that in two standard cell sections. The head-end laboratory section also included a continuation of the basement, first and second floor galleries that ran the length of T-Plant. However, these galleries turned at the head-end and continued across to the rear wall of the building.

\subsubsection{Galleries}

The HEW canyon buildings were so designed that the control panel boards, chemical and service distribution, were located in three galleries, one above the other along the "front" side of the building; the west side in the case of T-Plant and the north side in the case of B-Plant. The first gallery, at the basement level, was used principally for electrical distribution and control cabinets. The first floor gallery consisted of a piping loft containing steam, water, air, and chemical headers as well as piping connections between the panel boards and weigh tanks on the second floor and through-wall cell piping. The second floor gailery was the control center for the cell equipment, and was known as the operating gallery. Each 40-foot building section constituted a separate unit, and were controlled by separate gauge boards in the operating gallery. The gauge board panels were installed in a row along the barricade wall between the canyon and the galleries, with weigh tanks along both front and back walls of the gallery.

- Amercoat is a trademark product of the Ameron Protective Coatings Division, Ameron, Inc., of Brea, California. 
WHC-MR-0521, Rev. 0

\subsubsection{Canyon}

The lower portion of the canyon below the "deck" (ground) level contained 40 individual concrete cells having removable concrete cell-block covers. The cell covers were constructed with overlapping, step-wise edges, to contain the radiation within the cells. A 10 -foot (3.05-meter), 6-inch (15.24-centimeter) square exhaust duct ran along the back wall of the building paralleling the bottom of the cells and was connected by an underground concrete duct to the 291 Exhauster Buildings and Stacks for the removal of cell fumes. Immediately above this duct was a pipe trench which also paralleled the cells, containing inter-connecting cell piping. The pipe trench was also covered with removable, sectional concrete block covers.

The construction of the cells was standardized as much as possible, to ease the maintenance problems as much as possible. The sections having standard designs were 4 , and 6 through 20 . Section 1 differed in that it was a large cell with two long openings for the immediate storage of partially precessed material. Section 2 contained two long openings of the same size, one of which centered over the railroad track where irradiated fuel elements were brought into the building, and the other which housed initial cell equipment. A reinforced concrete railroad tunnel, extending 150 feet from the front sides of the buildings provided rail service to this section. Section 3 differed in that the pipe trench ended opposite cell \#5. Section 5 differed in that cell \#10 was much deeper, because it served as a collection point for drainage to the sewer section. At T-Plant, the head-end sections differed in that the pipe trench terminated in a manner that would allow for future extension of the building if desired. (Such extension did not happen.)

\subsubsection{Processing Equipment}

The equipment installed in the cells consisted mainly of centrifuges and vessels with and without agitators, and connecting piping between cell walls and equipment. Around the periphery of each cell were 42 flanged piping connections serving the cell equipment. Special piping connectors were used allowing pipes, conduits, and instrument leads to be connected by tightening a single nut. Vertical connectors were used for electrical connections only, and horizontal connectors were used for piping and instruments only.

The canyon portion of each Cell Buildings was served by an overhead bridge crane equipped with 75-ton and 10-ton hooks as well as four independent monorail hoists of one and one/half-ton capacities. The crane cab was designed to contain special controls, observation and communication facilities in order to remove cell blocks, cell equipment and cell piping by remote control. The canyons also each contained a second overhead bridge crane, 10-ton capacity for maintenance use only, when the building was completely shut down.

\subsubsection{Stair Towers}

Four-story reinforced concrete stair towers were constructed along the front side of each 221-T Building (eight in T-Plant and seven in B-Plant) to provide access to the three gallery levels and the crane-cab runway. These stair towers also housed heating and 
ventilating equipment and rest rooms for the galleries. Reinforced concrete labyrinthed stair towers were built along the rear sides (east side in the case of T-Plant and south side in the case of B-Plant), to provide access to the canyon portion of each building at the deck level. T-Plant had ten such rear stair towers and B-Plant had nine. ${ }^{87}$

\subsubsection{Bulk Reduction Buildings}

The 224 Buildings were constructed of reinforced concrete. Each was a three-story frame structure with concrete and concrete block exterior and interior walls. The front of each 224 Building was placed precisely 150 feet from the back of its corresponding 221 Building, and in line with the front of its process group's 222 Control Laboratory. Each 224 Building contained a total of 21 rooms not including two stair towers, one closet, one janitor's closet, and an elevator "penthouse." The overall dimensions were 60 feet $(18.29$ meters) 1 inch ( 2.54 centimeters) by 197 feet $(60.05$ meters) long, with a total area of 11,982 square feet ( 1113.16 square meters). Each building was 40 feet (12.19 meters) high for the majority of its length, but reached higher elevations over two stair towers and over the small penthouse arisa.

The foundation of each 224 Building was comprised of reinforced concrete walls with spread footings, reinforced concrete piers and beams, and concrete pads. Each floor slab was reinforced concrete 4 to 12 inches (10.16 to 30.48 centimeters) thick. Each roof consisted of flat reinforced concrete 5 to 12 inches (12.70 to 30.48 centimeters) thick, covered with built-up felt, gravel surfaced roofing, and containing 8 wood frame ventilators with meters. The roof slabs were removable, so as to allow the movement of large equipment pieces in and out.

Each 224 Building was essentially divided into two main sections: the process cell section, and the office and operating gallery section. The back side of the main structure contained the process cells and had one foot thick concrete walls with a balcony running around three sides. The 27-foot (8.23-meter) by 197-foot (60.05-meter) process cell area contained five cells known as Cells $A$ to $E$ inclusive. These cells were served by a handoperated overhead crane. Cells $A$ through $D$ measured 27 feet ( 8.23 meters) by 28 feet ( 8.53 meters). Cell $F$ measured 25 feet ( 7.92 meters) by 51 feet ( 15.54 meters), was L-shaped, and had an office in one corner of it. A glass enclosure was located in the cell against this office wall, where the partially finished product was collected for transfer to the 231-Z Isolation Building. In Cell $C$, the right-hand portion was a pit which connected with an underground pipe tunnel that ran from the center line of Sections 13 and 14 in the corresponding 221 Building to each 224 Building.

The floors in the cells were sloped to a trench along the wall, for gravity delivery to waste collection tanks. The walls and floors in Cells $A$ through $E$, and walls, floors, and ceilings in $\mathrm{F}$ Cells and its office were painted with Amercoat. A mezzanine floor extended across the side facing the corresponding 221 Building. Gauge boards and weigh tanks used in connection with Cell $F$ were mounted on this mezzanine.

One-foot (0.30-meter) thick interior walls divided the process cell section of each 224 Buildings from the office and gallery section. The "front" (offices and gallery) side of the main structure was reinforced concrete frame with 8 -inch $(20.32$-centimeter) concrete 
WHC-MR-0521, Rev. 0

block panels and 8-inch (20.32-centimeter) and 4-inch (10.16-centimeter) concrete block partitions. An elevator was installed adjacent to the No. 1 stair tower and was provided with an outside concrete loading platform to facilitate the movement of chemicals to and from trucks. The first floor contained offices, a chemical storage room, and other service rooms. The second floor was principally a pipe loft containing five concrete vestibules opposite each centrifuge platform. All chemical and service lines entered the building on this level. The third floor was an operating gallery that contained gauge boards, tanks, and instruments. ${ }^{88}$

\subsubsection{Isolation Building}

The 231-Z Building was located in the western portion of the 200-West Area of the Hanford Site, midway between T-Plant and U-Plant. Originally, this structure was a twostory, flat roofed, reinforced concrete, frame building with 8-inch concrete block panels and 4-inch (10.16-centimeter) and 8-inch (20.32 centimeter) concrete block partitions. Overall dimensions were 147 feet ( 44.8 meters) by 189 feet ( 57.61 meters) 10 -inch ( 25.40 centimeters) by 24 feet ( 7.32 meters) 6 -inch (15.24 centimeters) tall, with a total of 27,964 square feet (2597:94 square meters). A one-story ventilation and equipment room ran along the west end of the building. The $231-\mathrm{Z}$ facility had no windows.

In World War II, the 231-Z Facility contained a total of 57 rooms including 20 laboratories, several process and chemical receiving and storage rooms, offices, change room facilities designed to accommodate 190 employees, air conditioning equipment, a distilled water system, ventilation and exhaust systems, and a compressed air system. Six of the laboratories were known as "cell laboratories," and served as the major centers where the actual Pu isolation process was carried out. All of the rooms except for one rest room were located on the first floor, with the second floor serving as a pipe and service loft containing duct work and filters for the ventilation and exhaust systems.

The interior of the 231-Z Building was configured with two 8 foot (2.44-meter) wide, north and south corridors, $A$ and $B$; one on each side of the (6) cell laboratories with emergency exits to the outside of the building. Corridors $C$ and $D$ ran east and west, connecting with corridor $\mathrm{B}$. Corridors $\mathrm{E}$ and $\mathrm{F}$ ran north and south separating laboratories and intersect corridors $C$ and $D$. Two concrete stairways led to the second floor, and below-grade piping led to a waste disposal system. This piping was modified in 1948 to achieve additional control of $231-Z$ process wastes.

The 231-Z Building foundations consisted of reinforced concrete piers with spread footings and concrete walls with spread footings. Floors were reinforced concrete varying from 4 -inches (10.16-centimeters) to 12 -inches ( 30.48 centimeters) in thickness. The walls and ceilings of the cell laboratories and Vaults $A$ and $B$ were reinforced concrete 1 foot thick. The roof was likewise reinforced concrete 4 -inches thick and was covered with built-up felt, gravel surface roofing containing numerous openings for intake and exhaust ducts. The walls, floors, ceilings, and equipment in rooms 1 to $6,8,27,31$ to 45, Vaults $A$ and $B$, and corridors $A, B, C, D, E$, and $F$ were painted with "Amercoat" to obtain non-porous surfaces. ${ }^{89}$ 
WHC-MR-0521, Rev. 0

\subsubsection{The Bismuth-Phosphate Process}

The bismuth phosphate essentially dissolved the jackets off of irradiated $U$ fuel elements, then dissolved the fuel itself, and then carried out a series of precipitations followed by centrifugation and re-dissolving of the precipitate cake. The valent state of the Pu-239 (known as "product" at this stage) was manipulated so that it would stay with, or separate from, the various solutions and precipitate cakes produced in the operations. In the +4 (tetravalent) state, the Pu-239 would carry with the bismuth phosphate-based solutions. In the +6 valent state (hexavalent), the Pu-239 would not carry with the bismuth phosphate, and a by-product precipitation could be achieved. The plutonium was reduced (taken to the tetravalent state) by adding oxalic acid or ferrous ions, and oxidized (taken to the hexavalent state) by adding sodium bismuthate (when bismuth phosphate was the carrier), or potassium permanganate (when lanthanum fluoride was the carrier). Actually, lanthanum fluoride was known to be a better carrier of plutonium, in that it could carry with a smaller bulk or volume and could carry away the stronger lanthanides such as Cs, Sr and La. However, it was/is very corrosive, and for that reason it was rejected for the main phase of the Hanford separations process.

\subsubsection{Dissolving}

The first step in the separations process carried out at HEW was dissolving, a process that removed the aluminum fuel jackets from the uranium elements. It was carried out in the dissolvers and metal solution storage tanks located in Sections 3 and 4 (Cells 5, 6 and 7) of the canyon buildings (T- and B-Plants). The irradiated, jacketed fuel rods first were placed in boiling sodium hydroxide, to which sodium nitrate slowly was added (reduce the formation of hydrogen). This step produced "coating removal waste." Next, three metric tons of declad metal were charged into a dissolver. Nitric acid was added in three increments, enough to dissolve one ton in each increment. In order to keep the time cycle as short as possible, "a substantial metal heel" was left in the dissolver between charges. New material was charged on top of this heel.

\subsubsection{Extraction}

The second step in the process was the extraction step. This operation separated the product (Pu-239) from most of the uranium. It also removed about $90 \%$ of the fission products into what was called the metal waste solution. The extraction step reduced the gamma radiation activity level by a factor of 10 . In the first extraction step, plutonium was kept in the +4 (reduced) valent state. Bismuth nitrate and phosphoric acid were added to the solution that contained the dissolved fuel elements, causing the formation of bismuth phosphate. A product precipitation (one that carried the Pu with it) then occurred. The precipitate was centrifuged to separate the solid portion from the liquid. The liquid portion was jetted away as waste. The solid portion ("precipitate cake"), which contained the Pu, was placed in another tank and dissolved with nitric acid. Sodium bismuthate or potassium permanganate were added to the plutonium-bearing solution to oxidize the $\mathrm{Pu}$ to the +6 state, and then sodium dichromate was added as a holding agent to keep the Pu steadily fixed in this state. The BiPO4 then precipitated as a byproduct, leaving the $\mathrm{Pu}$ in solution. 


\subsubsection{Decontamination}

The third step, decontamination, essentially was a repetition of the extraction process. The final decontamination cycle reduced the gamma activity level by a factor of 10,000 , giving an overall process "decontamination factor" of 100,000 below that of the original uranium solution. The plutonium-bearing solution from the extraction step was reduced with the addition of ferrous ammonium sulfate. Then, bismuth nitrate and phosphoric acid again were added, a product precipitation occurred, and the precipitate was centrifuged. The solid portion, containing the $\mathrm{Pu}$, was liquified with nitric acid, oxidized, and the remaining BiPO4 precipitated away as waste..$^{90}$

\subsubsection{Bulk Reduction Process}

Plutonium-bearing solution was transferred from the "tail" ends of the canyon buildings to the 224 Buildings via underground piping. The starting batch size in the latter facility was 330 gallons. Here, the Pu solution from the 221 buildings was oxidized with sodium bismuthate. Phosphoric acid then was added to produce a byproduct precipitation, leaving the $\mathrm{Pu}$ in solution. Centrifuging then separated the solution and precipitate. Nitric acid was added to dissolve the byproduct cake, and it became waste. Next, the plutonium-bearing solution was oxidized with potassium permanganate (KMnO4). Hydrogen fluoride and lanthanum salts were added, in what was known as the "crossover" step. A lanthanum fluoride precipitate was produced, leaving hexavalent Pu in solution.

Impurities were precipitated in a byproduct cake, as the fission products were carried with the lanthanum. This byproduct cake contained all of the lanthanides (cerium, strontium, lanthanum, etc.) that the BiPO4 could not carry out of the stream. The cake was dissolved in nitric acid, neutralized with sodium hydroxide, and sent to tanks for settling. The plutonium solution then was reduced to +4 state by adding oxalic acid. Lanthanum salts and hydrogen fluoride again were added, thus precipitating lanthanum fluoride that contained the Pu. The precipitate was separated by centrifugation, and potassium hydroxide was added to metathesize the Pu lanthanum fluoride, forming a solid Pu lanthanum oxide. (Metathesis is a chemical process to convert a solid to another solid.) Any liquid was removed by centrifugation, and the solid Pu lanthanum oxide was then dissolved in nitric acid to form Pu nitrate. By this time, the original 330 -galion batch that had entered the 224-T Building had been concentrated to eight gallons (volume). ${ }^{91}$

\subsubsection{Isolation Process}

Lastly, the plutonium nitrate from the 224 facilities was sent to the $231-z$ Building for the final processing that could be done at the Hanford Engineer Works. Hydrogen peroxide, sulfates, and ammonium nitrate were added to the plutonium-bearing solution. The hexavalent Pu precipitated as plutonium peroxide. Nitric acid then was added to dissolve this precipitate. The Pu nitrate then was placed in small shipping cans and boiled right in these cans, using hot air. It was reduced to a wet nitrate paste. In this form, the 
Pu was stored in the $213-\mathrm{J}$ and $\mathrm{K}$ vaults in the southeast end of Gable Mountain, and then shipped to the secret Los Alamos Site. Each shipping can held about one kilogram $(\mathrm{kg})$ of $\mathrm{Pu}^{92}$

\subsubsection{Earliest Operations}

Operating experiences during the initial months of canyon operations were described by DuPont as unusually satisfactory. ${ }^{93}$ No serious mechanical problems developed, except that the bowl of the centrifuge in Section 16 of T-Plant jammed against some dip tubes when it was run backwards on January 5,1945 . The centrifuge was replaced via remote operations, partially decontaminated in a spare cell, and then buried in 1954 when it was determined that it could not be repaired. This and other miscellaneous remote tasks gave operators confidence that "the Canyon Buildings can be operated remotely as planned and with somewhat less loss of fabricated equipment than originally anticipated." 94

During the next six months of canyon operations, procedures were standardized. Technical efforts were directed towards reduced time cycles, as production sped for the special nuclear materials needed to win the war. By mid-1945, emphasis had shifted to "a review of process technology and operating technique in an effort to improve efficiency and reduce waste losses. "95 Free nitric acid concentration was reduced to obtain an increase in the specific gravity of dissolver solutions. The most significant improvement, however, came in the late summer, with the installation of piping to allow for intermediate solution transfer from storage to the precipitators in Section 6 (Celis 11 and 12). This was a safety measure, as metal solution slightly in excess of charge requirements then could be taken from storage, agitated, and sampled so that the correct amount, based on critical mass limitations, could be transferred to the extraction sections of the plant. Further safety improvements included more rigorous efforts to empty and decontaminate the precipitators used in the extraction and decontamination cycles. These measures assured the prevention of Pu-239 buildup on equipment.

\subsubsection{Early Process Changes}

The original HEW separations canyons were designed on the basis that one plant would have the capacity to process the output from one pile (reactor). With each HEW reactor originally planned to produce one metric ton of metal (containing approximately 250 grams of product - Pu-239) per day, the earliest standard procedure for T-Plant involved starting a one metric-ton charge of metal into the dissolvers about every 26 hours. However, by the summer of 1945 , production tests had shown that charge size could safely be increased to 1.5 metric-tons of metal, "without noticeable effect of vield or equipment performance." ${ }^{16}$ By September 1, process modifications enabled the plant to complete the processing of a charge in just 20 hours, with only a $10 \%$ allowance added onto the average process cycle for equipment repairs.

Other very early changes included the elimination of potassium carbonate from the separations process in February 1945, and one month later, due to the unavailability of potassium hydroxide containing only $0.0005 \%$ iron impurity, the relaxation of process 
specifications for this chemical to allow for $0.005 \%$ iron impurity. Overall, the first fullscale separations experiences at T-Plant and at the 224-T Bulk Reduction Building and the 231-Z Isolation Building, led to large reductions in many essential materials, per unit of production. For example, the strength of the key dissolving agent nitric acid was decreased from an average of $95 \%$ to an average of $69 \%$ (a $33 \%$ reduction). By September 1,1945 , other chemical requirements were reduced by an average of $41 \%$, and potassium carbonate had been eliminated from the process altogether.

Additional and ongoing process improvement studies carried out during the 1945-46 period were directed at: simplification of operations to achieve reductions in process time, modification of the process to increase canyon capacity per batch, reduction in waste volumes, recovery of additional product from wastes, the establishment of better understandings of process safety and safety limits, decontamination improvement, and basic studies in the chemistry of plutoniurn. Such studies were pursued in the T-Plant semi-works (Cells A and B), in HEW's 300 Area (in the 3706 Radiochemistry Building and the 321 Separations Building).

\subsubsection{Operations Lessons Learned}

During 1946, much experimentation was done in T and B-Plants to lower further the quantities of phosphoric acid required in the product precipitation steps of extraction and decontamination. Reductions in the molarity of this acid, as well as in sodium hydroxide and calcium carbonate were achieved successfully. Additionally, the "problem of batch size control and prevention of product accumulation received attention throughout the period."97 New connector assemblies were installed in order to bypass certain process vessels where the headroom was insufficient to allow for in-tank agitation and where, consequently, product-bearing precipitates might settle. Acid washings of catch tanks in the precipitation cells also were increased, to prevent Pu-239 accumulation, and sampling of standpipes and other transfer lines was increased.

During $1947-48$, the periscope assemblies in the 75-ton crane in each canyon building were altered to increase eyepiece tube diameters, to coat the lenses, and to provide rebuilt mirror mounts. Small equipment decontamination stations were emplaced in 1948, and in 1950 equipment and services were installed in the plants to supply dual precipitation solutions to sections 19 and 20, thus allowing parallel operation. The most major modifications of the early operating years concerned the dissolver off-gas filtration systems, but much of this work occurred outside the canyons in the ducting and stacks of the 291 facilities, and at the 292 Gas Sarnpling Laboratories. lodine removal filters were installed at the outlets to the canyon dissolver cells in 1950.

By 1950 , the Hanford plutonium production rate had increased by $299 \%$ over the 1946 rate, and research and development had cut the processing time cycle by $45 \%$. In 1952, due to the success of HW's new REDOX Plant, B-Plant closed as a radiochemical processing facility. In 1954, T-Plant achieved a $30 \%$ rise in processing capacity with the acquisition of a third dissolver. Operational improvements continued at T-Plant to the extent that in 1955, the average processing time cycle dropped to 4.5 hours. $^{98}$ 
WHC-MR-0521, Rev. O

\subsubsection{End of Bismuth-Phosphate Operations}

In 1954, a program was devised at Hanford known as the $4 \times$ Program, because it would utilize all four of the then-existing and planned Site processing facilities ( $B$ - and T-Plants, REDOX and PUREX) for active chemical separations. The program was an attempt to respond to the rapidly growing national demand for plutonium production. During 1954-55, B-Plant underwent some modifications to re-activate as a more efficient and prolific plutonium separations facility. At the same time, T-Plant was being studied for refurbishment for increased production, and designs were drawn for emplacing a third extraction cycle in T-Plant. However, in January 1956 the new PUREX (plutoniumuranium reduction extraction) Plant began operations at the Hanford Site and soon demonstrated such overwhelming efficiencies that the $4 X$ Program was abandoned. T-Plant was shut down as a processing facility in March 1956, and the decision was made not to reactivate $B$-Plant. ${ }^{99}$

\subsection{REDOX (REDUCTION-OXIDATION) PROCESS}

Experimentation and design for the Hanford Site's REDOX (reduction oxidation) Plant began in 1947, with actual construction beginning in late 1949. The facility commenced operations with hot feed in January 1952. Located in the far southeast corner of the 200 West Area, the REDOX building was shorter than the previous HW re-processing facilities, but had a tall "penthouse" or "silo" at the tail end to accommodate the "packed columns" used to attain contact between the aqueous and organic solvents and the feed solution in the final steps of Pu purification. The building was 467.5 feet (142.49 meters) long, 161 feet ( 49.07 meters) wide, 82 feet (24.99 meters), 9 inches (22.86 centimeters) tall in the canyon area, and 131 feet ( 39.93 meters), 10 inches (25.40 centimeters) high at the silo. It was constructed of thick, reinforced concrete. Like the WWII processing facilities, it operated most of the process remotely, in nine below-grade, thickly-shielded concrete cells designated $A$ through J. Operating, Pipe and Sample galleries were located on the north and south sides of the canyon. Also like B- and T-Plants, the REDOX Plant began the process by dissolving first the fuel jacketing and then the solid $U$ fuel core. REDOX was unique, however, in that it was the first radiochemical processing facility in the world to operate with a continuous (non-batch), solvent extraction process. Its chemistry was based methyl isobutyl ketone (MIBK, also known a hexone), used at full strength with no diluents. Aluminum nitrate was added as a "salting agent." The REDOX process involved a continuous progression of the hexone/Pu nitrate solution through ion exchange columns that successively purified the $\mathrm{Pu}$ and removed fission products. ${ }^{100}$

The real advantage and attractiveness of the REDOX plant and process, however, was its efficiency. REDOX was designed for an average uranium production rate of 1 to 2.5 tons of natural irradiated uranium per day. Maximum design basis production rates were assumed to 3.125 tons per day if equipment operated with $80 \%$ efficiency. By April 1952, the plant achieved its design rate, and at the end of 1952, REDOX had exceeded its design rate by $50 \%$ in some months. A series of three "Capacity increase" projects began in 1953, with the result that the production rate increased to 2 to 3 times the plant design rate in 1953 alone. By the end of 1954 process changes resulted in an instantaneous uranium throughput capacity of eight tons per day (Phase II design rate 8.3 tons per day). 
Additional improvements brought the design rate to 9.3 tons per day and throughput of 11 to 12 tons per day were realized by 1958 with the Phase III Capacity Increase project.

Part of the Phase II Capacity Increase project constructed the 233-S Plutonium Concentration Building just north of, and adjacent to, the REDOX Silo. Completed in 1957, the new building carried out the third and final Pu concentration cycle in the traditional evaporative manner, but in very tall, thin, equipment designed for criticality safety with enriched material. Processing of enriched irradiated uranium fuel assemblies ("E-metal") began at REDOX in 1958. E-metal throughput initially was limited to approximately 3 tons per day, due to criticality considerations inside the REDOX Plant. However, when multi-purpose, annular dissolvers (those having a smaller vessel inside a larger vessel) were installed, and other process improvements initiated, throughput to 12 tons of irradiated enriched fuel per day was achieved. During 1961-62, new anion exchange $\mathrm{Pu}$ concentration equipment was installed in the 233-S Building. It operated until a serious fire virtually destroyed the state-of-the-art concentrator in November 1963. REDOX then returned to traditional means of Pu concentration, but the anion exchange technology already had proven itself at the new PUREX Plant. ${ }^{109}$

\subsection{THE PUREX PLANT}

\subsubsection{Genesis and Need for the PUREX Plant}

Although REDOX, as it was being constructed in 1950, was expected to be far more efficient than T-Plant and B-Plant, new national defense projections drawn up by the AEC and the Department of Defense (DOD) as the Korean War escalated in late 1950 and early 1951 still showed a gap between capacity and need. Additionally, the REDOX chemistry, although workable, was not ideal. Hexone is an organic with a relatively low flash point $\left(81^{\circ} \mathrm{F}\right)$, so many components of the REDOX plant had to be built to explosion-proof standards. Also, the aluminum nitrate could not be recycled and re-used, thus rendering the plant expensive to operate both in terms of fresh chemical consumption and waste storage. ${ }^{102}$ In September 1951, a Facility Study Group was formed by at HW to examine "Program X": the development of a new separations plant. The new facility, it was determined quickly, would need to be capable of processing 200 metric tons of irradiated, aluminum-clad uranium per month (MTUIm), exposed to neutron bombardment at an average level of 600 megawatt days per ton (MWD/T) and aged not less than 90 days, given an $80 \%$ overall efficiency rate. Further, the plant would need to have a built-in potential to increase to $400 \mathrm{MTU} \backslash \mathrm{m}$ with certain equipment changes. This capacity would be necessary to handle the material that would be generated by the twin "jumbo" reactors, 105-KE and 105-KW, new plants also planned for HW.

Specific design engineering for the new separations processing facility began in July 1952. construction began in April 1953, and the PUREX plant was essentially complete by April 1955. "Cold" runs (tests with unirradiated materials) were initiated in late 1955, and "hot" startup (work with radioactive substances) commenced in January 1956. 


\subsubsection{PUREX (202-A) Building}

The PUREX plant, as originally built, was a concrete rectangle 1,005 feet (306.32 meters) long, 104 feet ( 31.70 meters) high (with approximately 40 of those feet below grade), and 61.5 feet (306.32 meters) wide. It's main "canyon" portion, approximately 860 feet (262.13 meters) long, contained 11 cells designated $A$ through $H$, $J, K$ and $L$. Each cell was 14 feet (4.27 meters) wide, 42.5 feet (12.95 meters) deep and 39.5 feet (12.04 meters) deep from floor to underside of the reinforced concrete cover blocks. Cells $A, B$ and $C$ housed metal dissolution equipment and activities, Cell D was designated for metal storage, Cell E contained the equipment that prepared the dissolved metal into feed solution for the PUREX process, Cell $F$ housed waste treatment and acid recovery operations, Cell $G$ was for organic recovery (sometimes called first cycle solvent recovery), and Cells $H, J, K$ and $L$ incorporated the remainder of the solvent extraction and concentration steps. Cell $\mathrm{K}$ was specifically for uranium decontamination and Cell $\mathrm{L}$ was for plutonium decontamination. ${ }^{103}$

Additional portions of the PUREX building were comprised of a Hot Pipe Trench (an 860 -foot ( 31.70 meters) by 12 -foot ( 3.66 meters) by 33 -foot ( 10.06 meters) enclosure that housed pipes that transported radioactive solutions), and an Air Tunnel [an 860-foot (262.13 meters) by 11 -foot (3.35 meters) by 7.5 -foot $(2.29$ meters) space through which contaminated air from the canyon and the process ventilation system passed on its way to the filters and the 291-A Stack]. Also, paralleling the cells on the side opposite the Hot Pipe Trench and air tunnel, were the crane cab gallery, the pipe and operating ( $P \& O$ ) gallery, the sample gallery and the storage gallery. A 40-ton general utility or "main" crane (also known as the remote crane) serviced the canyon, along with a 40-ton auxiliary or "slave" crane. The slave crane was operated on a level 17 feet (5.18 meters) above the main crane, and was designed to handle tall pieces of equipment such as columns, concentrators, dissolver towers and some pipe jumpers. The main crane was equipped with a closed-circuit color television, the first in a Hanford processing plant, for viewing the canyon area. Additionally, a regulated area of the 202-A Building contained M-Cell with a water pool for decontamination of major process equipment, and a "hot shop" and a regulated shop for decontamination and repair of smaller equipment having varying levels of radioactivity. The decontamination cell incorporated leaded glass windows and flexible jumpers for the first time in a Hanford processing plant.

Adjoining the north wall of the main 2012-A building was a 750 -foot (228.60-meter) long, 60-foot (18.29 meters) wide service area that contained three control rooms (central, head end, and power unit), the PUREX process control laboratory, the aqueous make-up and storage area, and the acid concentration vault. An underground solvent storage and make-up facility was located adjacent to the service side of the 202-A Building.

\subsubsection{Unique PUREX Design Features}

The design of PUREX equipment and systems incorporated several unique new features. Among these, the most important to overall operations were the use of pulse columns rather than packed columns or mixer-settlers to achieve actual chemical separation, and the development of "liquid-liquid-solid-type centrifuges." The packed columns used in the REDOX plant were ruled out early in the design of the PUREX plant, 
because a height reduction of $50 \%$, with attendant financial savings, could be achieved if other means were used to attain contact between the aqueous and organic solvents and the feed solution. Soon after that, pulse columns were selected as the design choice, because solids could be removed from them more easily than from mixer-settiers, and because the smaller volume per unit capacity of pulse columns would permit faster detection of off-standard conditions. In the three years from 1950 to 1953, 50 man-years of research and development was applied to perfecting the PUREX pulse column design. One of the new design features was the insertion of swirl plates into the columns at several heights, to improve contact and mixing of the aqueous and organic solutions by reducing channeling effects. Additionally, in L-Cell, the first "packed pulse" column to be used at Hanford was installed as the $2 \mathrm{~A}$ column. Also, in a special agreement with a subcontractor, the first three-phase, 48-inch (121.92 centimeters) bowl centrifuge of its kind in the world was developed during the first nine months of 1953 , for use in the PUREX process. ${ }^{104}$

Other unique design features in the PUREX plant included an irradiated fuel element storage basin, the first of its kind located within a separations facility, a railroad tunnel designed to permit unloading of contaminated cask cars without compromising the ventilation system, and a "soft wall" at the east end of the building that consisted of concrete blocks and grout that could be removed for the installation of an additional crane, or to enlarge the building at a future date. In the ventilation system, an initial glass wool filter was chosen, instead of the sand filters used at previous HW processing plants. The overall ventilation system that served PUREX also was designed to have three times the capacity of the REDOX system, in order that air of considerable force could enter the cells when cover blocks were removed, and thus prevent the escape of contaminated particles from the cells into the canyon area. The PUREX jumpers, like most of the other equipment in the plant, were larger and longer than those at the REDOX facility, due to the greater depth of the process cells. Additionally, like other PUREX apparatus, they were standardized to be remotely removable and interchangeable. A single drawing and specification could permit the construction of as many as 27 jumpers. The jumpers also utilized pipe bends instead of expansion joints, to prevent the leakage that had occurred with such joints at other Hanford plants. "Debottlenecking," another unusual design characteristic within PUREX, meant that the piping was sized to accommodate $50 \%$ more flow than was expected, in order to allow for future expansions. ${ }^{105}$

Several unprecedented features also were built into the PUREX facility's instrumentation systems and equipment. Some of these devices were so rare that commercial vendors could not accommodate them, and many had to be fabricated in HW's 300 Area Technical Shops. Among such inventions was the $X$-ray photometer, used in the PUREX laboratory to determine the relative $X$-ray absorption properties of various process solutions. Additionally, in-line monitors, for the first time at HW, scanned a representative portion of the process stream and recorded the results on a continuous basis. These gamma energy spectrum monitors could scan 12 streams every 30 minutes without the removal of a single physical sample from the process, thus saving an estimated 3,000 hours of laboratory person-hours per month. Miniaturized instrumentation within a graphic panel display board, another unparalleled installation at PUREX, exhibited the readings of the crucial rotameters, pneumatic transmitters, electric interface detecting probes, and other sampling instruments. The Gilmont pipette sampler for the most 
radioactive substances, hydraulically filled and discharged by an operator in the sample gallery and attached to a separate ventilating hood, was another key innovation in PUREX appliances. ${ }^{\circ}$

The vertical "basket" type tube bundles used in the PUREX concentrator heat exchange units also were specifically designed for the plant. A number of remote maintenance puzzles and difficulties with the large remote flange were overcome in the design of this 12 -foot long equipment. The PUREX agitators also were unique, in that they had no gear boxes and no bearings below the motor to guide the long shafts. Such features were chosen to reduce the frequency of breakdowns. In another innovation, bearings in the pumps serving the PUREX canyon vessels were lubricated with process solution, while the drive bearings were lubricated by a permanent grease reserve. Again, these features served the needs of remote maintenance, and were designed to prolong equipment life. ${ }^{105}$

\subsubsection{PUREX Production Output}

By the standards of any other Hanford Site processing plant, the output of the PUREX facility was nearly beyond belief. The PUREX Plant was designed for a nominal processing capacity of from 75 to $200 \mathrm{MT}$ of uranium per month. Based on a $80 \%$ production efficiency a maximum instantaneous production rate of 250 tons of $U$ per month or 8.33 tons $U$ per day was used as the nominal design basis. During 1956 alone, the PUREX plant processed $56 \%$ of the total plutonium output of HW, and the 1956 total output was itself $59 \%$ above that of 1955. In September 1956. PUREX demonstrated a sustained, instantaneous rate of $16 \mathrm{MTU} / \mathrm{d}$, and an astounding on-line efficiency of $99 \%$. The following year, the total output of plutonium from HW increased by $54 \%$ over that of 1956, with PUREX processing $71 \%$ of this new total. That October, the plant demonstrated an instantaneous production rate of $20 \mathrm{MTU} / \mathrm{d}$, with a reduction in the amount of residual fission product activity in the product of 25 fold below design specifications. During 1958, the total HW output of plutonium increased five percent over that of 1957 , with PUREX contributing $79 \%$ of that total. That year, the decision was made to send virtually all of the standard irradiated uranium from the 100 Areas production reactors to PUREX, and to divert " 94 Metal" (enriched uranium containing $.947 \%$ uranium 235 by weight, also known generically as E-metal)) to the REDOX plant. $^{107}$

The late 1950s and early 1960s witnessed even more spectacular production leaps at the PUREX facility. A series of "reliability improvements" emplaced at the plant during 1959-61 brought enlarged and re-configured equipment. In October 1960, the plant reached the point of having processed 22,000 tons of irradiated fuel, thus surpassing the combined total of B-and T-Plants, and the REDOX facility, for all of their years of operations. For short periods of time, PUREX demonstrated the capacity to operate at 3.6 times its design capacity. The plant also exceeded its previous Np-237 production figures, by producing $92 \%$ of the national supply. During the five years including 1960 -

${ }^{a}$ No registered trademark can be found for the Gilmont sampler in the time period of reference. 
1964, the two HW separations plants processed approximately 35,000 tons of irradiated fuel, with PUREX handling about $80 \%$ of that total. In late 1965. PUREX systems were modified to allow the plant to sustain normal operations at a 4.0 capacity factor, or 33 $\mathrm{MTU} / \mathrm{d} .^{108}$

Beginning in 1963, the PUREX plant was modified to allow for the processing of various fuel types, including fuel from N Reactor. Since N Reactor fuel elements were much larger than the four to eight inch "slugs" from HW's single pass reactors, and were clad in Zircaloy-2, they were harder and slower to dissolve than the single pass reactor elements. In 1966, annular dissolvers and a special "Zirflex" process had to be emplaced in PUREX to accommodate N Reactor fuel. Annular dissolvers were needed because of the higher enrichment levels of $N$ Reactor fuel. The Zirflex process essentially consisted of dissolving the Zircaloy-2 coating with a mixture of ammonium fluoride and ammonium nitrate (known as AFAN), subsequent metathesis with potassium hydroxide, centrifugation of the coating waste for product removal, and then dissolution of the fuel elements themselves in nitric acid. ${ }^{109}$ Also, a "co-product insert" was emplaced in PUREX, in order to process the driver fuel elements needed to facilitate irradiation of the lithiumaluminate targets that produced tritium in N Reactor. By 1967, "125 Metal," enriched uranium containing $1.25 \% \mathrm{U}-235$ by weight, was being processed through PUREX, but always in conjunction with fuels of lower enrichment levels. The following year " 210 Metal," the driver material containing $2.10 \% \mathrm{U}-235$ by weight, also was being sent through the plant, again in conjunction with less reactive materials. ${ }^{110}$ Once the separation of $N$ Reactor fuel began in 1967, the entire context of production rates and numbers changed for PUREX. Whereas the processing 5,000 - 7,000 MTU per year (MTU/y) had been normal for the plant during the early years of the 1960s, when singlepass reactor slugs had comprised the irracliated portion of the feed material, the processing rate fell to about $2,000 \mathrm{MTU} / \mathrm{y}$ for $\mathrm{N}$ Reactor fuel.

\subsubsection{Long Shutdown Period for PUREX}

In 1972, the PUREX plant entered a temporary shutdown period that lasted for 11 years. The initial PUREX shutdown was planned for 18 months, to allow the accumulation of $\mathrm{N}$ Reactor fuel, and to clean out selected high-level waste tanks in the A Tank Farm. Sluicing was to be used to remove solids and associated heat content to permit re-use of the tanks for high-level waste storage. Other projects planned and completed during early shutdown period included the installation of a condensate recycle system, and a separate off-gas system for ammonia-bearing effluents. As the shutdown period progressed, the initial sluicing effort took longer than expected, and a startup delay to 1976 was announced in mid-1973. That time period coincided with some of the biggest changes in waste disposal and environmental policy in the history of the Hanford Site. The decision was made to store new wastes only in double-shell tanks, and the PUREX re-start was further delayed as double-shell tank farm facilities were constructed. ${ }^{111}$

During the shutdown period, other issues arose, including environmental concerns that led to providing upgraded filtration systems, seismic safeguards, backup power sources and many other projects. Increased safety concerns about shipping plutonium in nitrate form from PUREX in the 200-E Area to the Plutonium Finishing Plant (PFP) in the 
200-W Area, led to an additional delay. The shutdown period was extended while M-Cell and $\mathrm{N}$-Cell within the PUREX Plant to convert plutonium nitrate (the former primary PUREX product) to plutonium oxide. Preparation tanks were added to a partitioned section of M-Cell, and a complete precipitation, calcination, blending and oxide product can loadout process was installed in $\mathrm{N}$-Cell and in the adjacent pipe chase. The PUREX PR (product) handling and removal room also was modified to accommodate shipment of the oxide product to PFP, and additional changes were made to the loadout configuration of $O$ Cell, the facility built in 1962 for continuous neptunium purification. ${ }^{112}$ Additionally, upgrades were made to the primary and PR room stack systems, the treatment systems for nitrous oxide and ammonia bearing fumes, plant fire protection systems, facility security, the P\&O gallery, the hot shop, the UNH storage area, the heating and ventilation air systems, the backup generators, the $P \& O$ gallery filtration facilities, the lag storage tank, and to the structural safeguards to assure the integrity of PUREX in case of a seismic event. ${ }^{113}$

\subsubsection{PUREX Re-Start and Final Closure}

In 1983, the PUREX plant reopened with an operating limit allowing it to process up to 3,000 MTU/Y of N Reactor fuel, or about eight MTU/d. However, the highest sustained but short-term production rates in the ensuing years hovered near seven $M T U / d$, and the highest long-term rates hovered near three MTU/d. In 1985, prototype testing was undertaken in Hanford's 300 Area to modify the head-end of the PUREX facility so that the cladding of $N$ Reactor fuel elements could be sheared off instead of chemically dissolved. The physical shearing was desirable because the residues of chemically dissolved cladding complexed high level tank wastes. However, such modifications were delayed in the actual PUREX plant until after the final cold standby order came for $\mathrm{N}$ Reactor in February 1988. At that time, the shearing concept was revived, and plans began to be formulated to modify the head-end of the PUREX facility to permit the shearing of stainless steel-clad fuel from the Fast Flux Test Facility (FFTF). The bare fuel cores then would be dissolved in C Cell. However, due to the intervention of other problems at PUREX, and to uncertainties about the future of the FFTF, this project was never undertaken. ${ }^{114}$

The PUREX facility closed for about six weeks in early 1988 , following a safety violation, and again for a year beginning in December 1988, after steam pressures fell below levels necessary to support back-up safety equipment. Additional equipment repairs and improvements to waste handling systems also occurred during that closure period. After a stabilization run lasting only a few weeks, the plant again closed in early 1990 in order to prepare additional environmental and safety documentation and facility upgrades. In October of that year, it was placed on standby status by the Department of Energy (DOE - a successor agency to the AEC). A final closure order was issued by the DOE on December 1992. This decision brought the end of defence plutonium production and processing at the Hanford Site. In 1993, the PUREX Plant commenced a 5-year deactivation project to take it to a safe, long.term, low-maintenance mode awaiting final decontamination and decommissioning (D\&D) decisions. ${ }^{115}$ 


\subsubsection{Processing of Other Materials at REDOX/PUREX}

PUREX and REDOX processed small quantities of other irradiated fuels. In 1958, the PUREX facility began the recovery of neptunium 237 (Np-237) on an occasional batch basis from its normal product stream. Immediately, the plant became the AEC's prime supplier of this isotope. During 1962, both REDOX and PUREX were modified to permit the continuous recovery of $\mathrm{Np}-237$ without interfering with normal plutonium recovery operations. The PUREX Np-237 equipment was placed in $\mathrm{J}$ Cell and $\mathrm{Q}$ Cell. ${ }^{116}$ During 1965-1966, the PUREX facility processed 664 tons of powdered thorium oxide fuel targets that had been irradiated for the production of uranium $233(\mathrm{U}-233)$, an isotope desired for its potential use in weaponry and because it could be made from plentiful, natural thorium. However, the processing campaign caused plugging and other equipment and contamination problems within PUREX. A more successful campaign in 1970 processed $820 \mathrm{kgs}$. of pelletized thorium oxide targets. Shortly afterward, for reasons unrelated to PUREX, thorium oxide fuel was ruled out for large scale development at HW. ${ }^{117}$ In the later years of REDOX operation (1963-1967), Plutonium Recycle Test Reactor (PRTR) and Shippingport (Pennsylvania) Reactor fuels were processed. PUREX also reprocessed some PRTR fuel in 1972, as well as some Southeast Experimental Fast Oxide Reactor (SEFOR) fuel. Core dissolving of these mixed oxide fuels involved the use of a highly corrosive mixture of nitric acid and hydrofluoric acid, with the dissolver solution then blended with recycled uranium to achieve criticality control. 
Photograph 4-1. T-Plant Under Construction, 1944, Hanford Site.

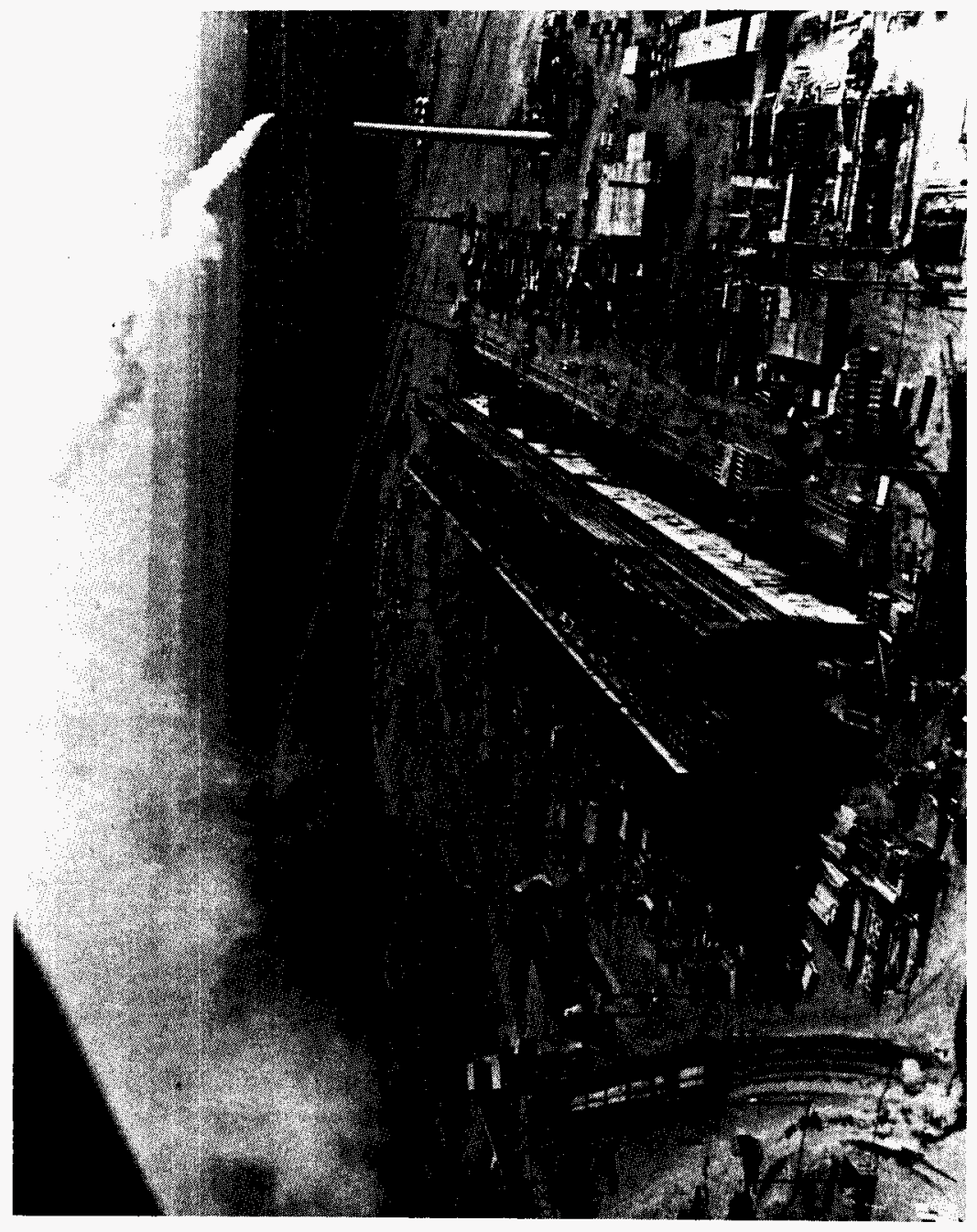


Photograph 4-2. B-Plant Instrument Gallery, 1950s.

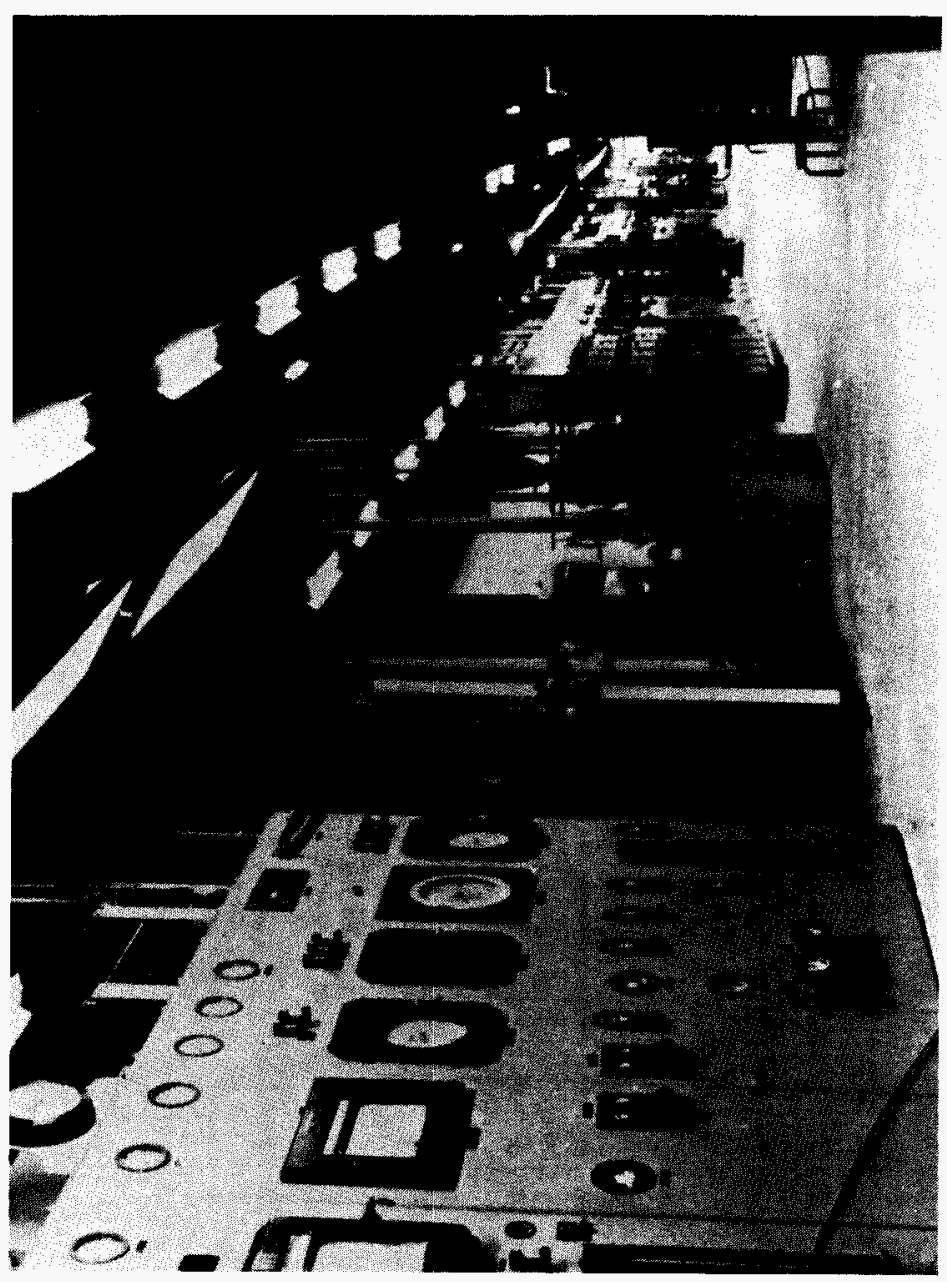


WHC-MR-0521, Rev. O

Photograph 4-3. REDOX (202-S) Under Construction, 3-27-51.

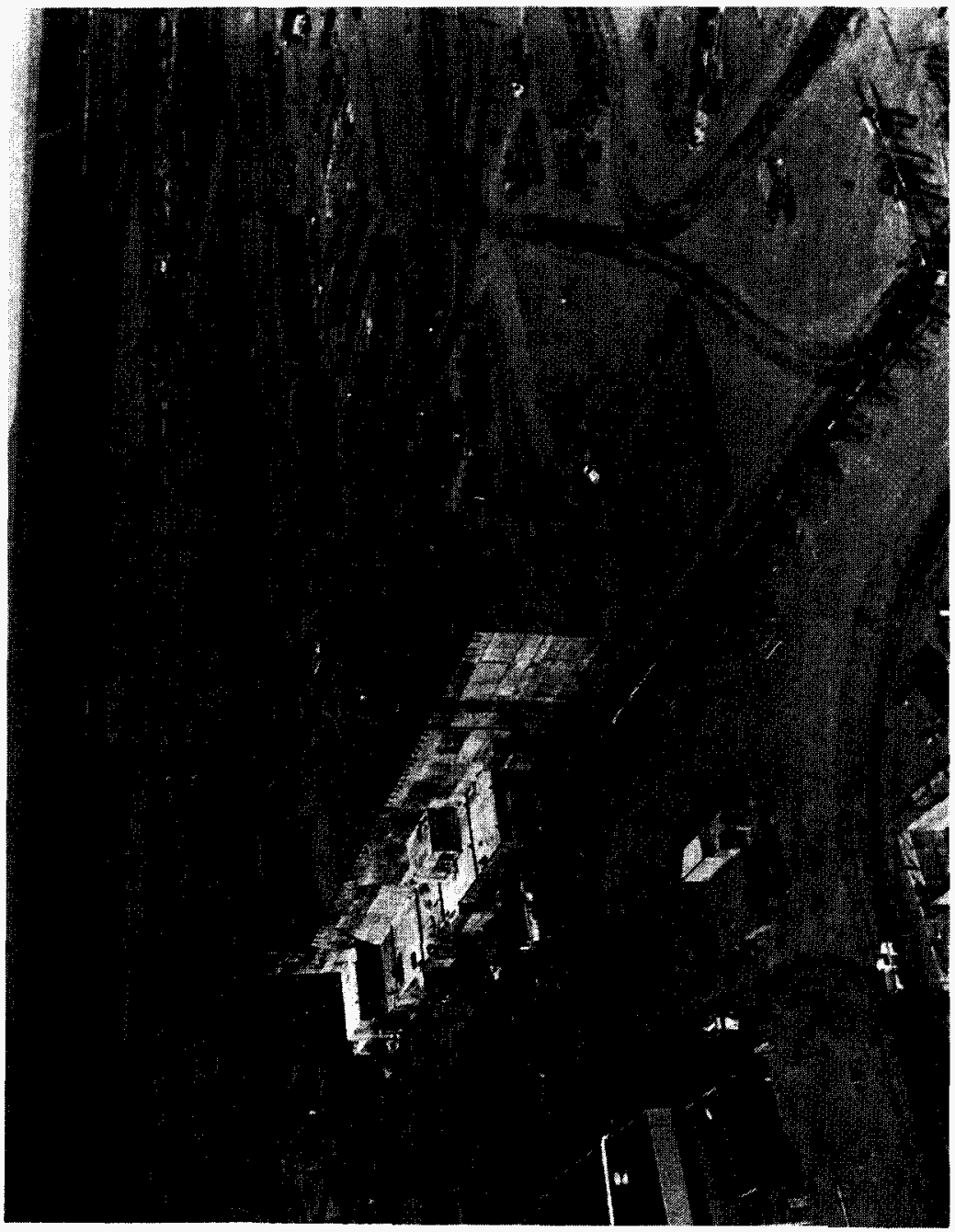


WHC-MR-0521, Rev. 0

Photograph 4-4. PUREX (202-A) Under Construction, 4-24-54.

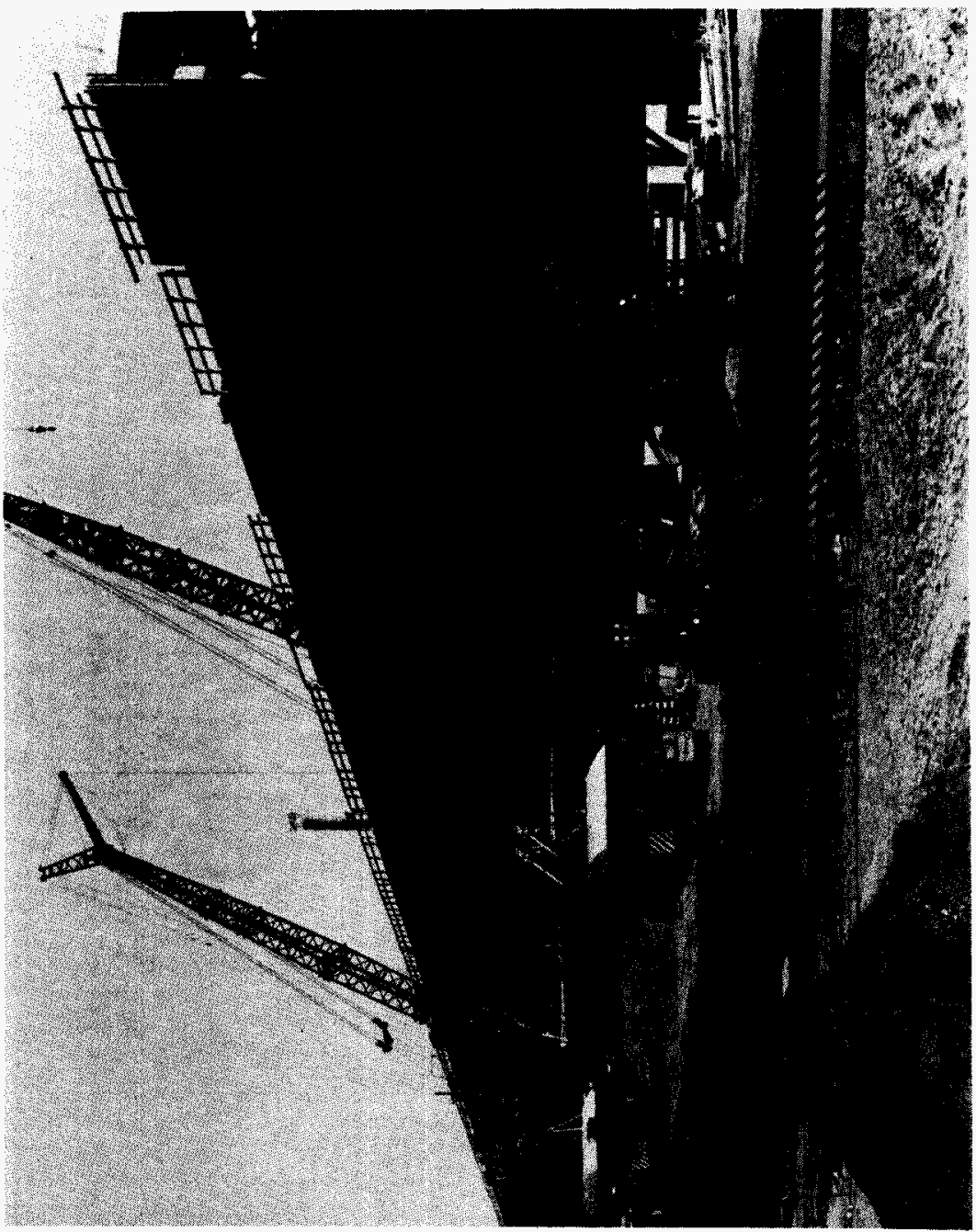


Photograph 4-5. Interior of PUREX Plant Under Construction, 1954-55.

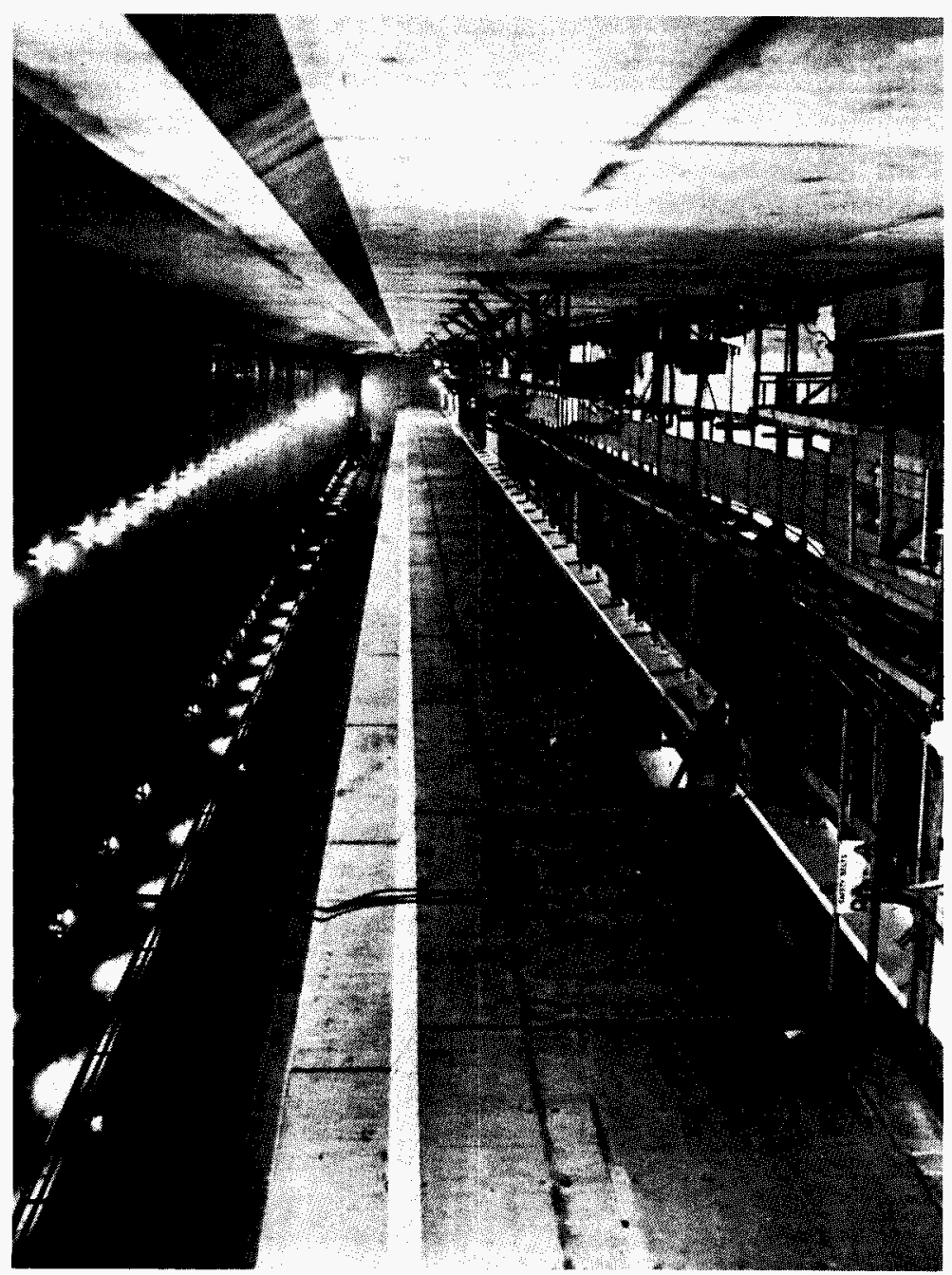


WHC-MR-0521, Rev. 0

Photograph 4-6. PUREX Equipment Installation, 1954-55.

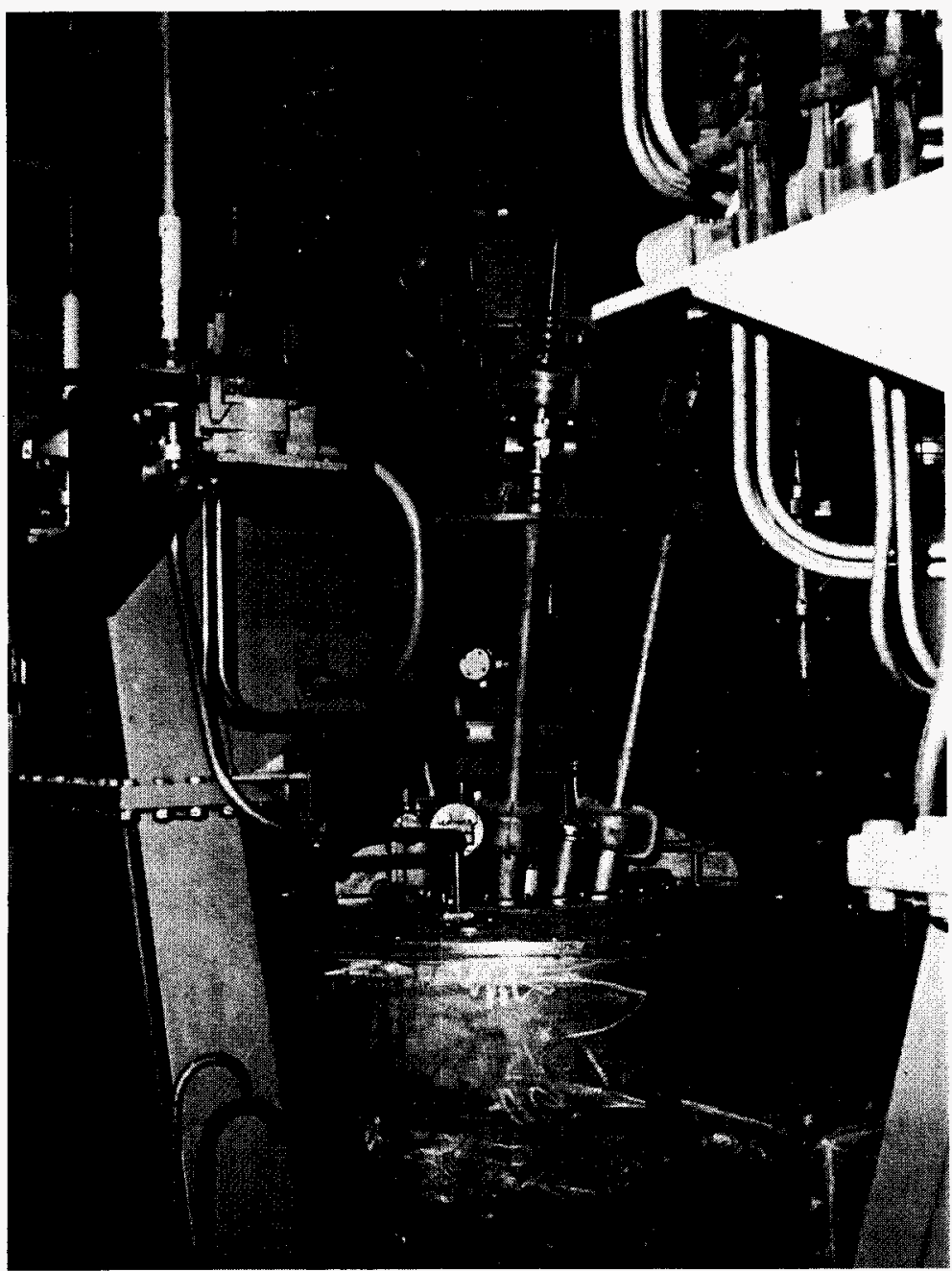


WHC-MR-01521, Rev. O

This page intentionally left blank. 


\subsection{PLUTONIUM FINISHING OPERATIONS AT THE HANFORD SITE}

Ever since WWII, the process of shipping Pu nitrate from the Hanford Site to the Los Alamos Site was seen as undesirable by the federal managing agencies (MED and then $A E C)$. Even though the nitrate product was "super-dried" to a thick paste in Hanford's 231 Isolation Building for safer shipment, and then re-diluted for the start of Pu finishing operations at Los Alamos, the concept of shipping non-solid forms of plutonium was viewed as less than an ideal. A process that would convert Pu nitrate product to metallic $\mathrm{Pu}$ at the Hanford Site was desired. As the first Cold War expansion got underway at Hanford in 1947, a key component of that program became the construction of plutonium conversion and fabrication facilities. Design began that year for the Project C-198, the building of the 234-5 Building (the Plutonium Finishing Plant - PFP) and the emplacement of a full Pu finishing line. Construction began in $1948 .^{118}$

\subsection{STARTUP OF PLUTONIUM FINISHINIG OPERATIONS}

According to a technical contractor report, the 234-5 Building was designed to be a "self-contained and independent plutonium fabrication plant with all necessary supporting services and facilities." A key specification was that "the chemical and metallurgical processes in use at Los Alamos be used." However, a main difference with Los Alamos was that, at Hanford, the "entire manufacturing process [was]...carried out within enclosed...hoods which are interconnected by tunnels." At Los Alamos, some steps of the process at that time were not executed in completely enclosed "hoods", and the hoods were not interconnected. ${ }^{b}$ With the increased volume of production planned for the Cold War, the additional safety factors inherent in a completely enclosed system were desired at Hanford.

The initial 234-5 plutonium finishing equipment was termed the "RG" (Rubber Glove) Line because it was not a remote, mechanized process. Its operation depended on personnel standing flush with the glove boxes and manipulating the Pu mixtures through rubber gloves that served as contamination barriers. The RG Line was composed of 28 stainless steel hoods, measuring 180 feet (54.86 meters) in total length. Plutonium handling activities took place in Zones 2, 3 and 4, with Zone 4 (inside the hoods) having the most negative pressure for contamination control. Metal plates extending from the floor to the hoods, and then from the hoods to the ceiling, separated Zones 2 and 3, so as to minimize cross-contamination from high-hazard to low-hazard activities. Air locks and

- NOTE: From the earliest 234-5 Building operations, Hanford personnel consistently referred to glove boxes as "hoods." The historical vernacular use of the term "hoods" is thus maintained in this text. However, the equipment being described as hoods actually are fully enclosed glove boxes.

b NOTE: In the terminology of the earlly Hanford and Los Alamos Sites, the word "hood" meant glove box (or "dry box"). Only later and slowly did the distinction between open-faced hoods and enclosed glove box'es enter the vocabulary in any consistent way. 
removable panels on the backs of hoods were used for Pu removal and maintenance. "Hot" processing (i.e., processing using Pu nitrate as feed) began in the 234-5 Building's RG Line on July 5, 1949.

\subsection{PU FINISHING PROCESS}

The basic plutonium finishing operations at the Hanford Site consisted of several standard steps known as "tasks." Task I, Purification or Oxalate Precipitation (also known as Wet Chemistry or Feed Preparation), consisted of precipitating the Pu nitrate feed solution with oxalic acid and other agents. In Task II, Hydrofluorination lalso called Dry Chemistry in the very early years), hydrogen fluoride gas was diffused through the precipitate at a very high temperature in a vacuum furnace, producing a plutonium tetrafluoride powder. In Task III, Reduction, the plutonium tetrafluoride was combined with calcium, a small percentage of gallium, and other agents and fired at very high temperature, again under vacuum, until it fused or "reduced" into Pu metal. The metal was produced in chunks roughly the size and shape of a hockey puck, and were known as "buttons." In Task IV, Casting, the Pu button was rendered molten and cast into a mold shape roughly approximating the desired "pit" (weapon hemisphere) shape. In Task V, Machining (also known as Shaping), the pit was ground and lathed to precise, specified dimensions and configuration. Shape specifications always were very secret, and still are classified today. In Task VII, Coating, the Pu metal pit was placed on a tripod and coated with nickel carbonyl gas, and through three separate applications to make sure that all portions of the bare Pu metal were covered. This coating served as a contamination shield during inspection, transport and storage. In Task VIII, Final Inspection, the pit was measured for wall thickness, uniformity of coating, neutron energy, isotopic content, dimensional precision, and any cracking. Tasks IX through XIV were identified as topics, not actual process steps. Instrumentation was Task IX, Control was Task X, Ventilation was Task XI, the Conveyor System (not present in the RG Line, but present in later 234-5 Building process lines) was Task XII, Maintenance of equipment was Task XIII, and Sampling was Task XIV.

\subsection{RMA (REMOTE MECHANICAL A) STARTUP, MODIFICATIONS}

Even as the RG Line was starting up in the PFP Building, design was underway for a $\mathrm{Pu}$ finishing line that would operate remotely, in a mechanized manner, thus providing an extra air space and contamination barrier between operators and the plutonium in the glove boxes. Known as the Remote Mechanical A Line (RMA of A Line) because it was the first of its kind at Hanford, the new process was completed and commenced hot operations at PFP on March 18, 1952. At first, the A Line performed all of the process steps in Pu metal production and fabrication except for Task I (feed make-up and purification). The RMA Line consisted of a row of 30 interconnected stainless steel glove boxes (still known as hoods), 30 control desks, 10 control cubicles, 24 instrument panels, nine resistance furnaces, five induction furnaces, a sample can handling assembly, a 110-foot (33.53-meter) long general conveyor and manipulator, other smaller conveyors and furnace loaders, and miscellaneous support equipment. It was located in six rooms in the 234-5 Building. 
WHC-MR-0521, Rev. 0

According to a contractor report: a "mechanically unpierced solid barrier...made of steel" with glass windows for "observing operations in Zone 4 (the space in the hoods where actual handling of product occurs)" was a key feature of the line. The barrier separated Zone 2 (the operating side) from Zone 3 (the equipment side). Office space and corridors in the 234-5 Building occupied Zone 1, the designation for the area with highest positive air pressure for purposes of contamination control. ${ }^{119}$

\subsection{RMA LINE CHANGES}

In early 1953, in response to the rapidly growing demand for increased plutonium production, the decision was made by the AEC to "modify and expand" the RMA Line. In May, various design proposals coalesced into two key projects: Activation of Task I, and Expansion of Building 234-5. Activation of Task I focused on building into the A-Line a new Task I process capable of bypassing the precipitation and purification activities then being carried out in Hanford's 231 Isolation Building. Expansion of Building 234-5 focused on a sweeping series of revisions to Tasks II and III (hydrofluorination and reduction), aimed at increased production and efficiency in the facility. This project also provided for the relocation and expansion of final product inspection facilities to the former quarters of the 234-5 maintenance shop, with the removal that shop's equipment and capability to the 272-W Area Shop. ${ }^{120}$

Throughout 1954, design and preparations associated with Activation of Task I and Expansion of Building of 234-5 consumed nearly all of the time and resources at PFP, except those energies that were devoted to production. During January and February of 1955, production operations shut down in the 234-5 Building, while the equipment was emplaced and activated for these two projects. The RMA Line then ran until mid-1957, when it was again closed briefly to install and activate equipment for Project GC-691. Improved Task I and Task II Facilities. This project emplaced a continuous calcination/hydrofluorination process that essentially combined the flow of Tasks I and II. ${ }^{121}$

\subsection{RMC (REMOTE MECHANICAL C) LINE CONSTRUCTED}

In the 234-5 Building, many projects were undertaken during the 1957-1961 period, in an effort to accommodate the vast production increases generated by the PUREX Plant and the increased reactor throughput. The most significant of these projects were the construction of the RMC Button Line and the RMC Fabrication Line. Both were undertaken officially in April 1957, and completed in late 1959. Actual operations with hot materials commenced in mid-1960. The RMC Line (both the button and fabrication components) consisted of a completely self-contained, remotely operated series of glove boxes very similar to the RMA Line. Like the A Line, $C$ Line functioned to convert Pu solutions to metal and then to fabricate actual weapons shapes from the metal. It differed from the RMA Line in that it had an automatic vacuum cleaning system that served Tasks I-IV, greater radiation shielding, and improved radiography facilities. The RMC Line was emplaced where the former RG Line (removed in 1957) had stood, and began hot operations in late $1960 .^{122}$ 
Other PFP upgrades in late 1950 s and early 1960 s included fire protection improvements, strengthening and refurbishment of the vacuum and exhaust systems, shielding upgrades, multiple waste management projects, improved Pu storage facilities, laboratory modifications, and classified modifications to the weapons shapes production equipment.

\subsection{END OF WEAPONS SHAPING WORK AT PFP}

In 1963, some classified modifications were made to the RMA Line to allow it to participate in a special, experimental AEC weapons fabrication program. During the second half of 1965 , a decision also was anrounced to remove the weapons fabrication work from the 234-5 Building and to concentrate that work at the Rocky Flats and Savannah River Sites. In Hanford's 234-5 Building, defense production remained high throughout 1964-65, but the weapons fabrication program concluded in mid-December of the latter year. Layaway (but not yet removal) of the fabrication portion of the RMA and RMC Lines (Tasks $V$ onward) was undertaken immediately and essentially completed in March 1966. The metal conversion portions of the RMC Line (Tasks I-III) continued to operate, while Task IV was converted to bag-out and sealing for shipment operations. The RMA Line was taken out of service completelly. It remained closed until 1968, when Tasks I-IV equipment was cleaned out and re-activated to participate in PFP programs that prepared plutonium oxides in specified, tailored blends for commercial nuclear experiments and development. From that time forward, the A Line became known as the "oxide line" and the $C$ Line became known as the "metal line." 123

\subsection{NON-DEFENSE WORK INTRODUCED TO PFP}

At the same time that work in weapons fabrication was shrinking in the 234-5 Building, new initiatives were undertaken to interface with the burgeoning commercial nuclear industry. In late 1962, the AEC first investigated the feasibility and costs associated with receiving, storing and disbursing power reactor grade ("fuels grade") plutonium. The AEC wished to "buy back" Pu produced by power reactors that operated on uranium fuel supplied by the Commission. The economically valuable Pu would then be sold at a later date for use in research programs or for fueling plutonium recycle reactors. (The plutonium recycle concept was being tried at the PRTR in Hanford's 309 Building.) In early 1964, the AEC designated Hanford as the site for the full-scale implementation of this program. Pu would be separated from spent fuels and purified at Nuclear Fuels Services (NFS) facilities in West Valley, New York, and shipped to Hanford as Pu nitrate. ${ }^{124}$

During 1965-66, receiving, re-packaging and storage facilities were built into the 234-5 Building as the Plutonium Buy-Back Facility. The project was completed in May 1966. In the meanwhile, production of specially blended, non-defense Pu oxide for EURATOM (European Atomic Energy Community - a consortium of the governments of France, West Germany, Italy, the Netherlands, Belgium and Luxembourg) for commercial nuclear power development was begun in the PFP in September 1964. That same year, the 234-5 Building began supplying non-defense $\mathrm{Pu}$ (known as "unclassified $\mathrm{Pu}$ ") to Hanford's 209-E Critical Mass Laboratory for experimental purposes, and to NUMEC 
((Nuclear Materials and Equipment Corporation), for fuel development tests for the SEFOR. During occasional periods in 1965, non-defense Pu production constituted the majority of production at PFP. ${ }^{125}$

\subsection{WORK SCOPE CHANGES AT PFP}

Large-scale interaction with the commercial nuclear industry, nuclear research customers and foreign nuclear customers became a reality at PFP in 1966. As the commercial nuclear industry continued to expand, non-defense work went occupied about $30 \%$ of the PFP's time and effort by 1968 . However, $70 \%$ of the time and effort still was expended making Pu buttons that then were sent to Rocky Flats for shaping. Beginning in 1973, shortly after the shutdown of the PUREX Plant, defense material feed to the PFP dwindled. The mid- and late-1970s were devoted to largely to facility upgrades and to projects that achieved better control of effluents. During 1974-75, all of the Division of Military Application (DMA) equipment was removed from the PFP and buried. This equipment included the weapons shaping glove boxes from the A Line. During 1975-76, Pu-contaminated soil in the Z-9 crib just south of the PFP was mined and partially remediated. Upgrades and equipment with special capabilities was added at the $242-Z$ Waste Handling Facility, and at the 236-Z Plutonium Reclamation Facility (PRF - a multifaceted Pu waste handling plant). The aging $232-Z$ incinerator was closed permanently in 1973 , and the new, 2736-Z Pu storage vaults were finished during 1972-73.

\subsection{FINAL OPERATIONS AT PFP}

In 1984 and 1985 respectively, the PRF and the C-Line re-opened in response to the late 1983 re-start of the PUREX Plant and the defense materials build-up ordered by President Reagan. Both operated several campaigns on an as-needed basis until the PRF shut down in December 1987 and the RMC Line shut down in June 1989. After that time, the production of defense materials at the Hanford Site was over. Projects to refurbish the PRF and parts of the C-Line were stopped, and the DOE prepared an Environmental Impact Statement (EIS) on the impacts of various alternative means of stabilizing the many forms of Pu-bearing remnants and scraps remaining in the PFP and its adjacent facilities. At the present time, public comment and input is being given on this Draft EIS, while some interim stabilization activities on small material quantities goes forward at the PFP. None of the stabilization activities produces material that is directly usable for defense purposes. 
Photograph 5-1. 231-Z Building F'rocess Control Laboratory in WWII.

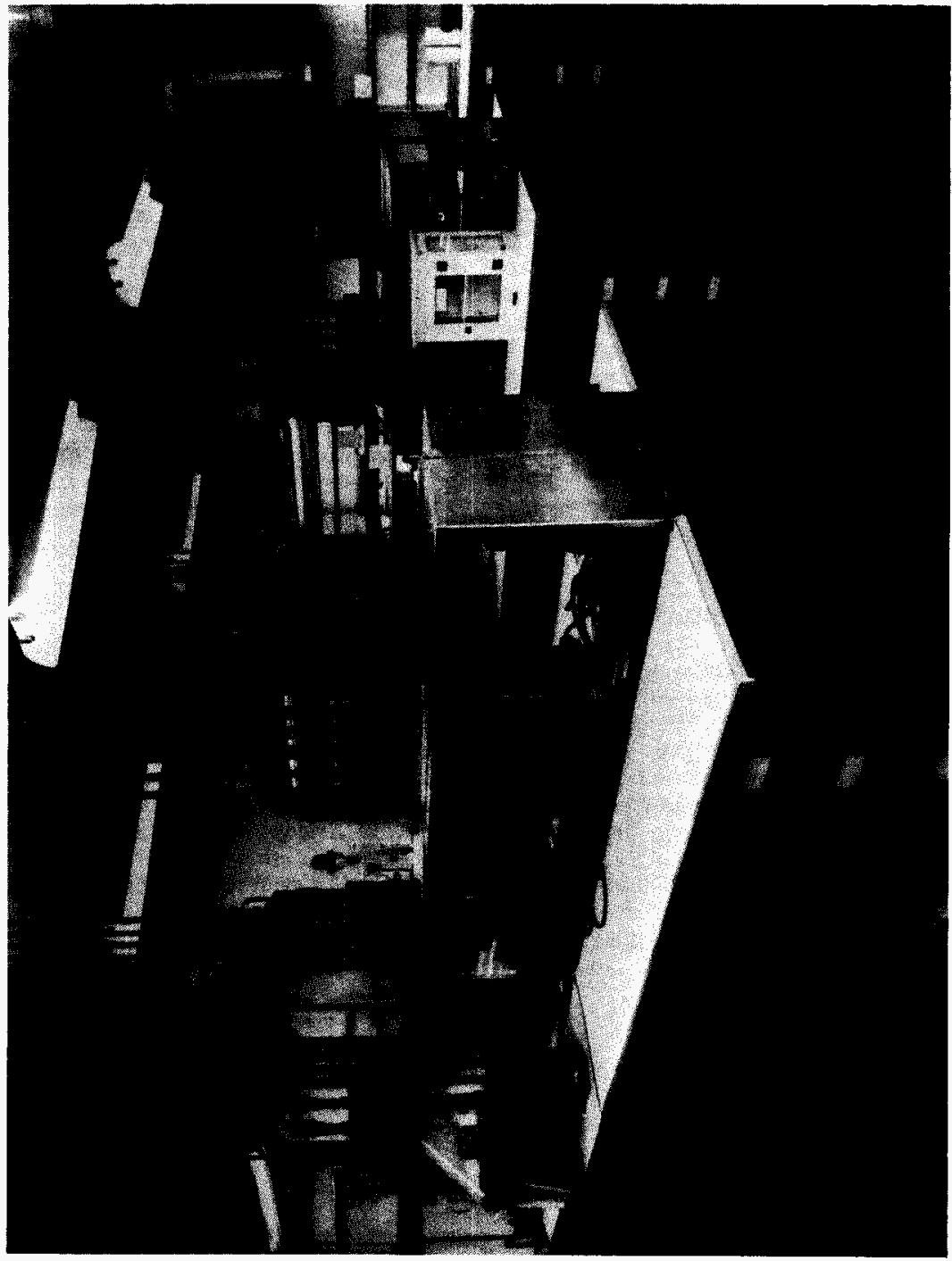


WHC-MIR-0521, Rev. 0

Photograph 5-2. Plutonium Finishing Plant, New in 1949.

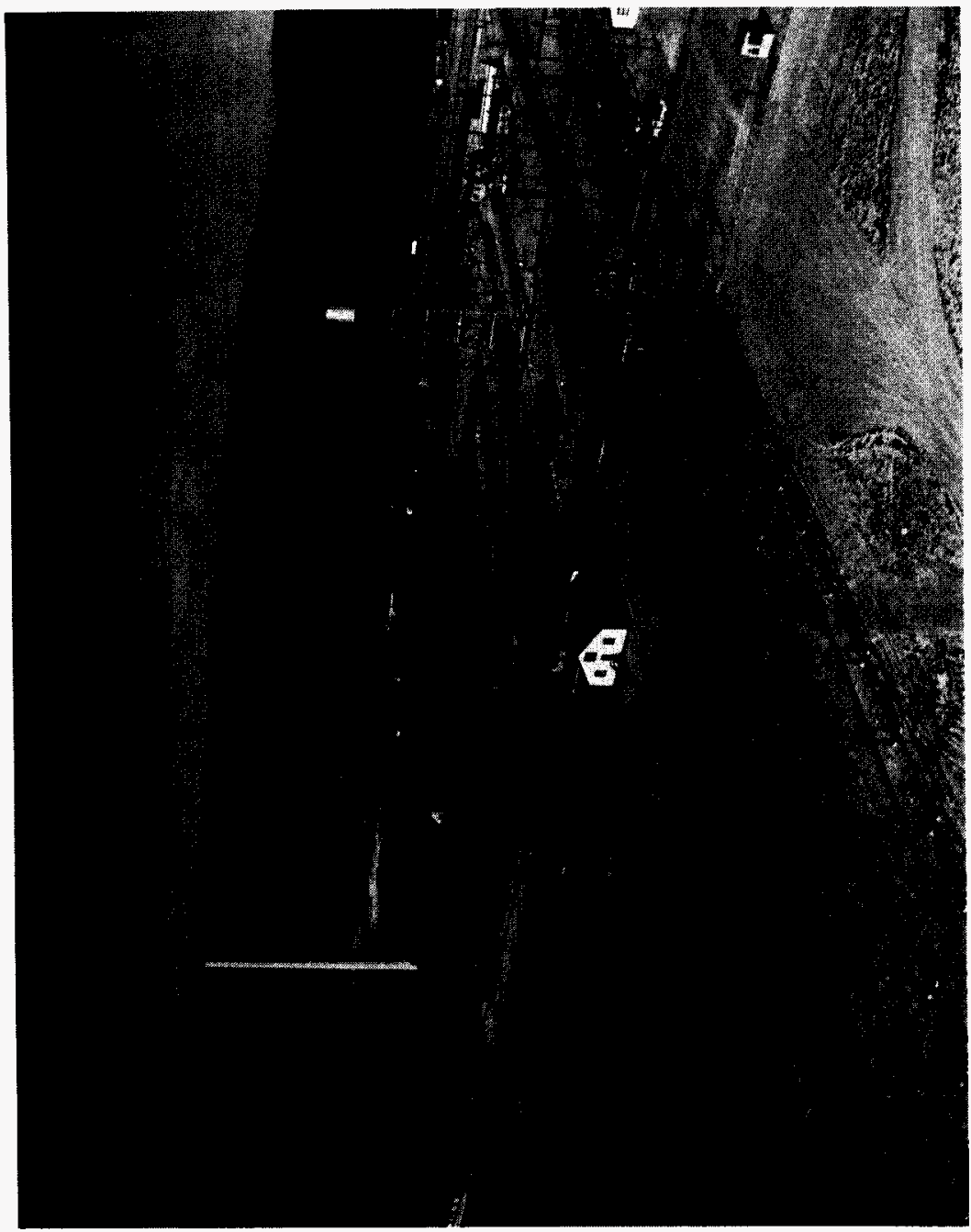


Photograph 5-3. Equipment of the "RG" Line Being Removed from Hanford Site's Plutonium Finishing Plant in 1954.

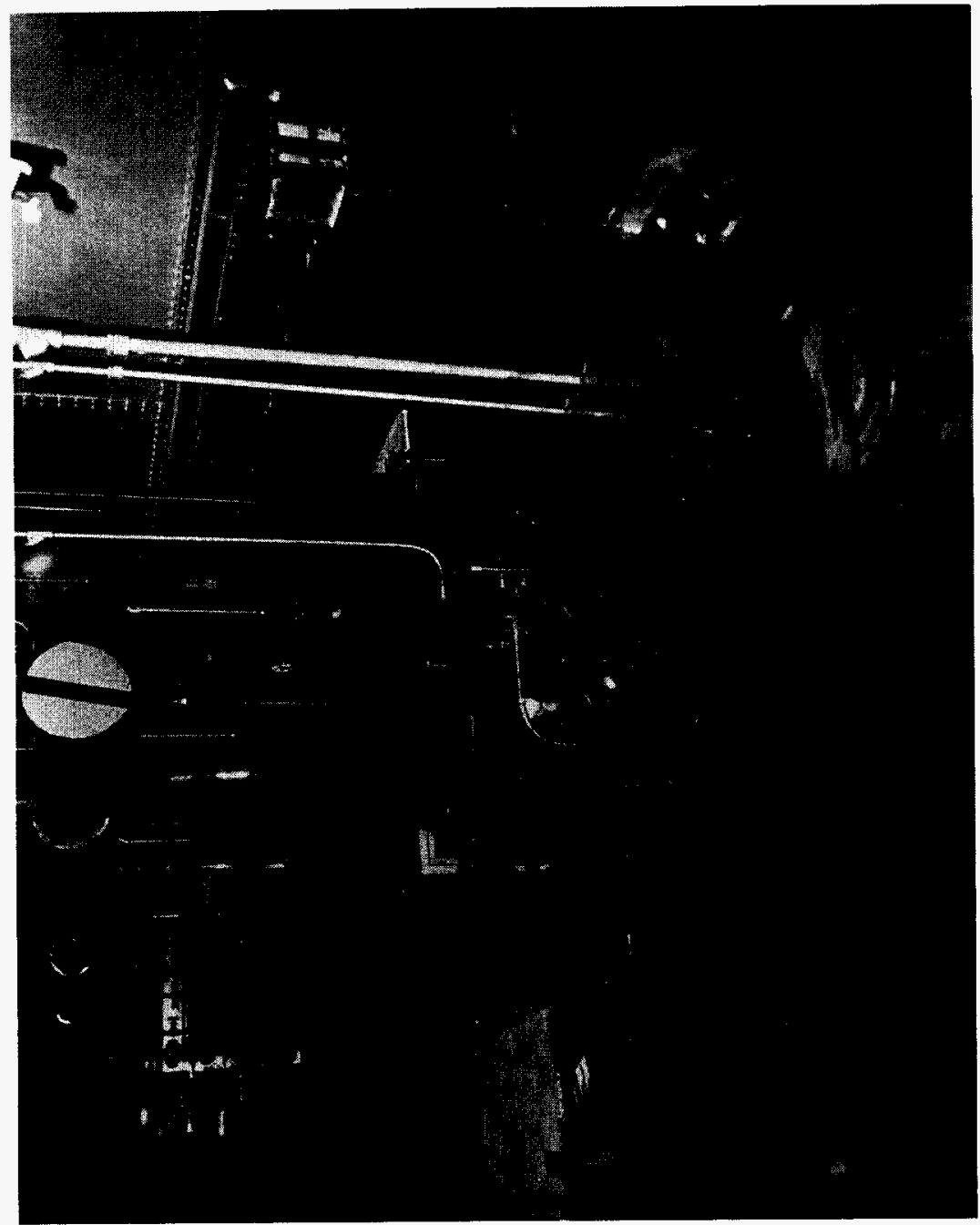


Photograph 5-4. Hanford Site's Plutonium Finishing Plant in 1963.

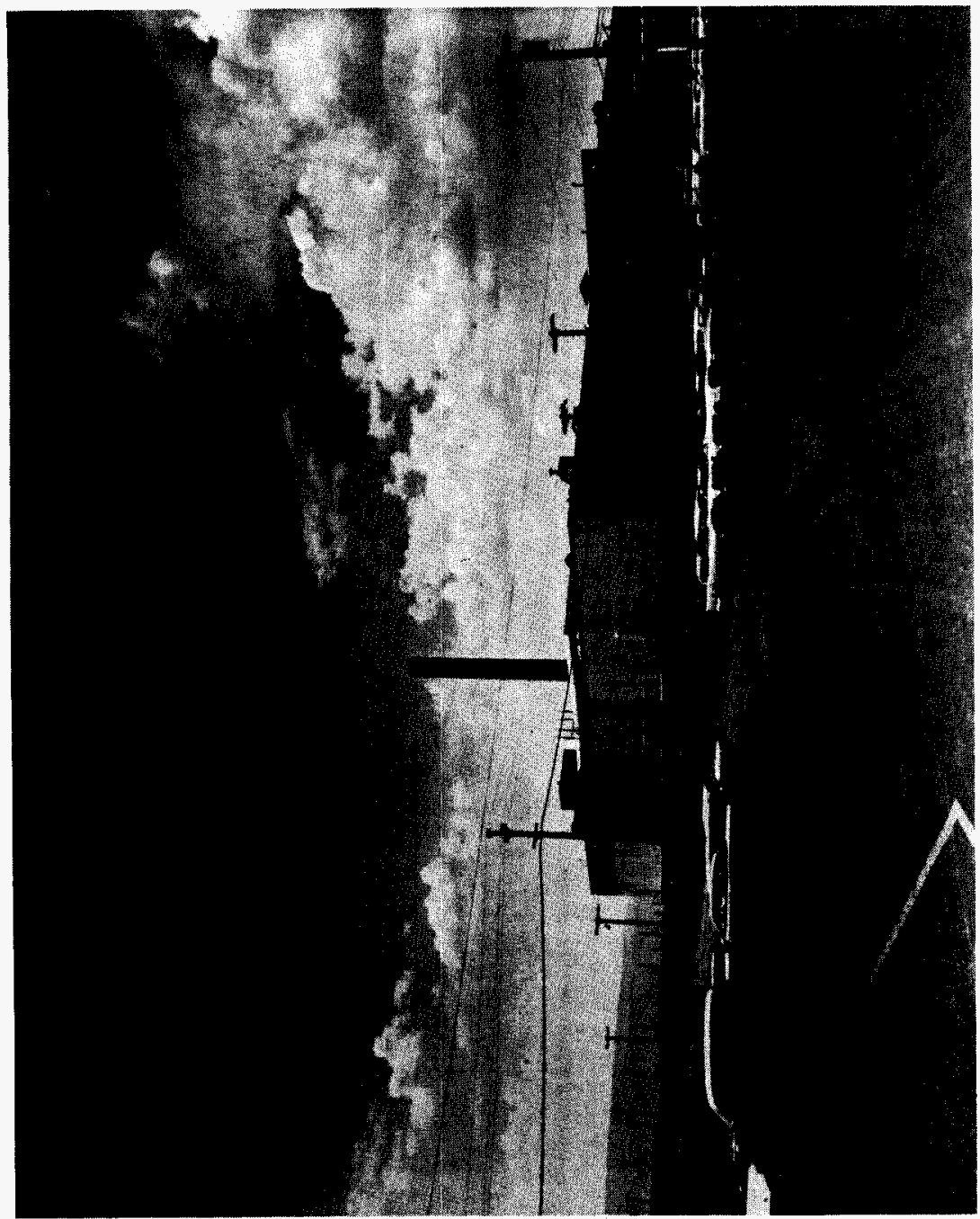


Photograph 5-5. Glovebox Used in Hanford Site Plutonium Finishing Plant's Plutonium Production, 1960s.

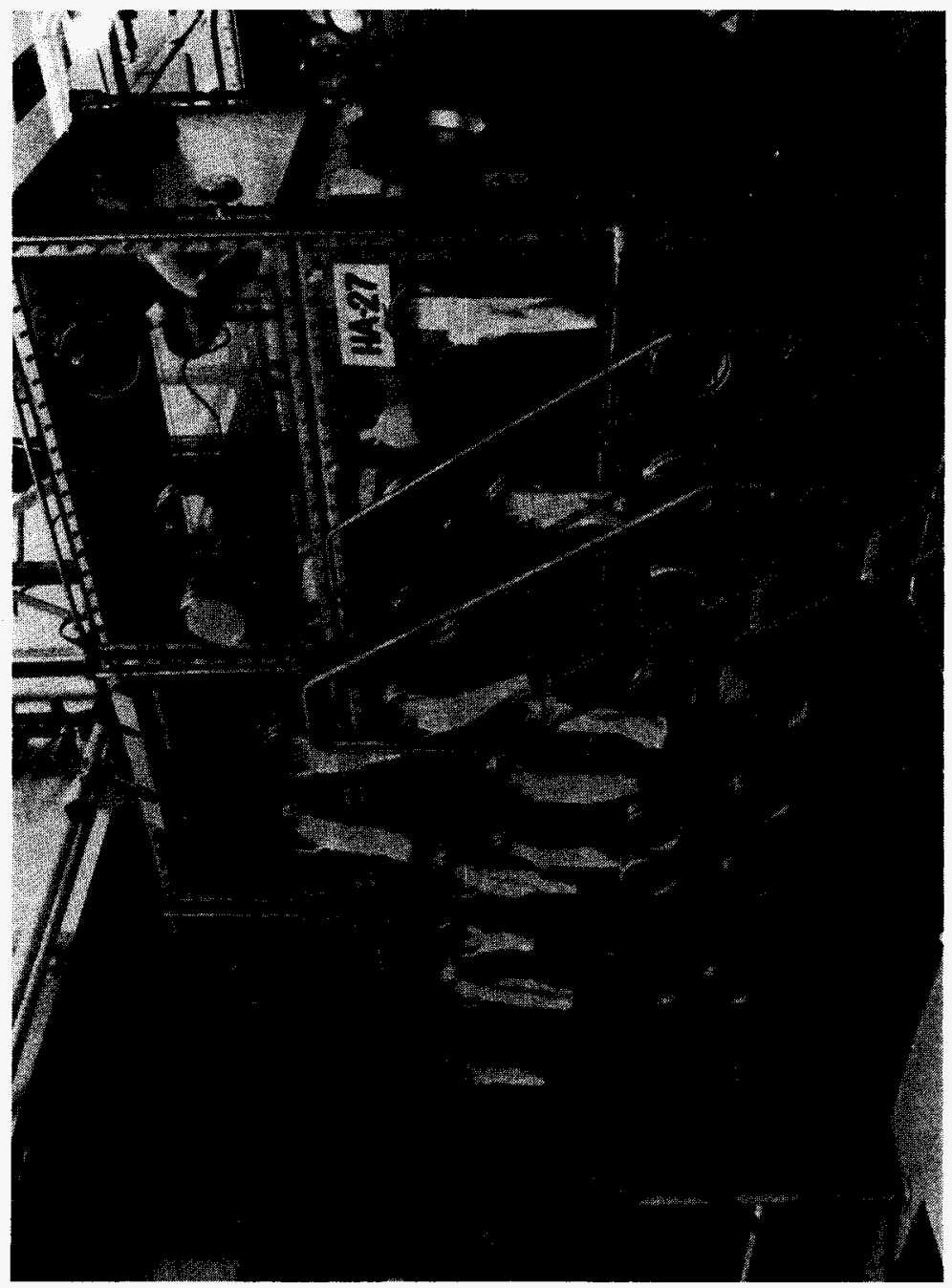


WHC-MR-0521, Rev. 0

Photograph 5-6. Plutonium Metal Button Produced

in the Plutonium Finishing Plant, 1980s.

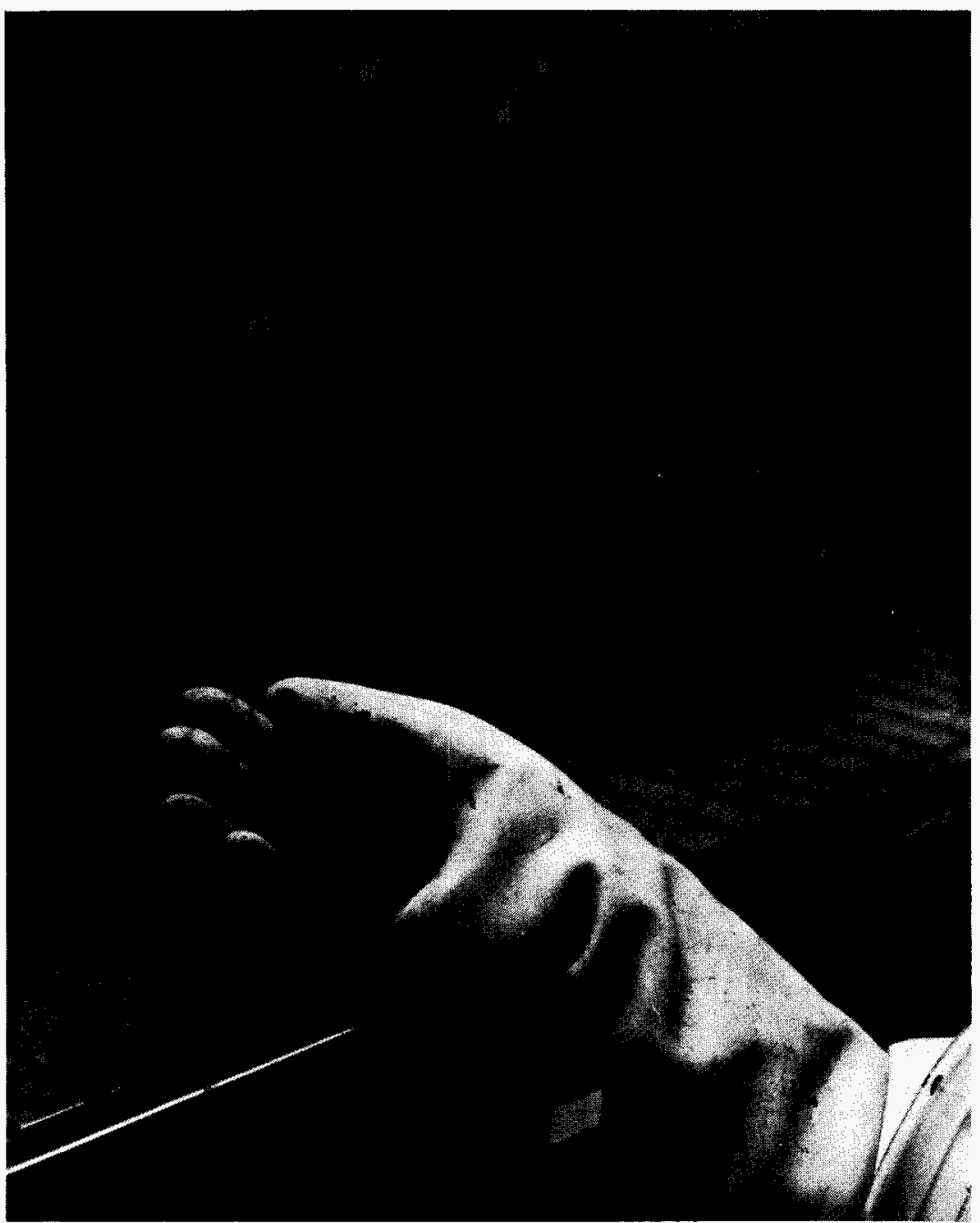


WHC-MR-0 521, Rev. 0

This page intentionally left blank.

5-12 


\section{ENDNOTES}

1. DuPont, Construction, HAN-10970, Vol. IV, pp. 997-999.

2. DuPont, Construction, HAN-10970, Vol. IV, pp. 997-1001.

3. DuPont, Construction, HAN-10970, Vol, IV, p. 992.

4. DuPont, Construction, HAN-10970, Vol. IV, pp. 1021-1022.

5. DuPont, Operation, HAN-73214, Book 10, pp. 19-26; and Simon, IN-03400, p. 1.

6. Hanford Engineer Works, HW-10475, Section A, pp. 1-28; DuPont, Operation, HAN-73214, Book 10, pp. 2-139; Weakley, HW-58115-DEL; Williams and Williamson, H-3-08393; Harlan and Williamson, H-3-8391; Kratzer, HW-21450.

7. Harrington and Reuhle, eds., Uranium Production Technology, pp. 5-12, 383-425; and Greninger, HW-14110, pp. 72-73; and G.E. Hanford Co., HW-7504 pp. 49-50.

8. Weakley, HW-58115-DEL; U.S. DOE, DOE/RL-90-11; AEC-GE Study Group, GEH-26434, p. 3.18; GE-Bouillon and Griffith, HWS-4955.

9. Drumheller, HW-47887; and Bell, HW-68662, pp. 3-8.

10. DuPont, Operation, HAN-73214, Book 10, pp. 24-26.

11. National Lead of Ohio, "Uranium Feed Materials..." pp. 14-15; Durum and Chamberlin, "300 Area Monthly Reports" (March 1946 and June 1946); Kidder, HW-7-4049.

12. Bixler " 300 Area Monthly Reports," 1947.

13. Bixler, "300 Area Monthly Reports," December 1947 and January 1948, pp. 1-2.

14. Bixler, "300 Area Monthly Reports," December 1947, January 1948, April 1948; Bixler, Special Hazards Incident Investigations," Class I, \#85 and $86(1948)$ and Class II, \#9 (1948); Hervin, "Radiation Monitoring Coverage," July 1954; pp. 1-2; U.S. DOE, DOE/RL-90-11, Appendix A.

15. Kent, HW-25906, pp. 5-6; Hochschild, HAN-49157-DEL; Corlett, HW-38332, pp. 1-6; Yost, HW-39945, pp. 1-4; Lane, HW-47260, pp. 1-4; Weakley, HW-24494, pp. 1-4; Weakley, HW-27321, pp. 1-2; Weakley, HW-27734, pp. 2-15, Brandt and Kraemer, HW-28282, pp. 1-4; Brandt, HW-29871, pp. 1-3; and p. 352; U.S. DOE, DOE/RL-90-11, p. A-10; Harrington and Reuhle, eds., Uranium Production Technology, p. 352.

16. Operation Managers, HW-59099, p. A-17; Operation Managers, HW-59463, pp. A-16-17; Operation Managers, HW-59717, p. A-22; Operation Managers, 
HW-60233-A, p. A-13; Operation Managers, HW-60505-A, p. A-18; Operation Managers, HW-63303, p. A-19

17. Batch and Toyoda, HW-65722, pp. 3-6; Toyoda, HW-71389; Thorne, BNWL-SA-1770; Operation Managers, HW-63740-A, pp. A-16-17; Operation Managers, HW-64108, pp. A-15-16; Geering, HW-66267; Operation Managers, HW-65459, p. A-18; Operation Managers, HW-65854, p. A-19; Operation Managers, HW-66237, p. A-14; Operation Managers, HW-67532, pp. A-16-17; Operation Managers, HW-67954, p. A-17.

18. Clemans, WHC-CM-5-20, Specification X-303.

19. Drumheller, HWS-6797; AEC/GE Study Group, GEH-26434, p. 3.36; U.S. DOE, DOE/RL-90-11; Clemans, WHC-CM-5-20; Gill, HW-69941.

20. U.S. DOE, DOE/RL-90-11, Section 3 and Appendix A.

21. U.S. DOE, DOE/RL-90-11, Appendix A and pp. 3.1 through 3.9 .

22. Hanford Engineer Works, HW-10475-B; DuPont, Construction, HAN-10970, Vol. III, pp. 719-735; Wahlen, WHC-EP-0273; IPD, "Maintenance Work Forecast, 1966;" Russ, HW-30401, Vol. I.

23. Hanford Engineer Works, HW-10475-B, pp. 1,105-1,210; DuPont, Construction, HAN-10970, Vol. Ili, pp. 788-792, and 806-811; Russ, HW-30401, Vol. I.

24. Russ, HW-30401, Vol. 1.

25. "Hanford Technical Manual," HW-10475-B; DuPont, Construction, Vol. III, pp. 788-792; DuPont, Operation, Book 7, pp. 79-115; Jordan, HW-3-1121; Hanford Engineer Works, OUT-1462, pp. 13-14.

26. Jordan, HW-3-1121; Jordan and O'Connor, HW-3-1913; Janos, HW-30083.

27. Menegus, HW-7-2744; Hanford Engineer Works, HW-10475-B; pp. 1110-1125; DuPont, Operation, HAN-73214, Book 7, pp. 107-114; Wende, HW-7-3486; Wende, HW-7-3834.

28. DuPont, Operation, HAN-73214, Book 15, pp. 138-141; Milton, HW-3-6898.

29. U.S. AEC, AEC-1140 p. 7; Fry, HW-43749.

30. Lewis, HW-07197; Haaga, HW-09603; Windsheimer, HW-11374; Maider and MacCready, HW-10079.

31. Carbon and Fryar, HW-20425; Warekois and Reinker, HW-19281; Cole, HW-21659; Reinker and Bupp, HW-33842; Curtiss, HW-55819.

32. DuPont, Operation, HAN-73214, Book 11, pp. 13-15; Handford Engineer Works, OUT-1462, pp. 64-69; DeNeal, DUN-6888. 
33. Wende, HW-13184.

34. Reinker, HW-22110; Strand, HW-27778; Russ, HW-30401, Vol. 1; IPD, HW-74094, Vol. 3; DeNeal, DUN-6888, p. 49.

35. Gast, HW-21761; Young, HW-65760.

36. Carbon and Fryar, HW-20425; Warekois and Reinker, HW-19281; Cole, HW-21659; Reinker and Bupp, HW-33842; Curtiss, HW-55819.

37. Windsheimer, HW-20841; Carbon and Fryar, HW-20425; Reinker, HW-22110.

38. Bupp, HW-29022; Reinker and Bupp, HW-33842.

39. Strand, HW-27778; Russ, HW-30401, Vol. I; Measley, HW-20379; Reinker and Bupp, HW-33842.

40. Jordan, HW-3-1121; Borgmier, HW-21199.

41. Koop, HW-21789; Warren, HW-22423; DeMers, HW-22687.

42. Wells, HW-27318; Pitzer, HW-25656; Dalrymple, HW-26395; Lewis and Rohrbacher, HW-29132; Strege, HW-32960.

43. Alexander, HW-23153.

44. Ritchey, HW-12492; Conley, HW-15943; Conley, HW-20342; Woods, HW-23163; Greninger, HW-25012.

45. Miller, HW-29406; Etheridge, HW-32664; Woods, HW-37698.

46. Fryar, HW-23361; Lewis and Rohrbacher, HW-29132; Wilson, HW-31043-Rev; Lutton, HW-27158.

47. Wahlen, WHC-EP-0273, p. 20; DeNeal, DUN-6888, p. 9.

48. Paul and Stephens, HW-34467; Greager, HW-37033; Call and Rector, HW-30863; DeNeal, DUN-6888, pp. 53-55.

49. Amy, HW-24492; Lovington, HW-315224.

50. Schilling and Hess, HW-25082; Lovington, HW-36224; Young, HW-43343; McCarthy, HW-43456; Carlson and Trumble, HW-62471.

51. Conley, HW-20342; Fox, HW-25345; Bupp, HW-28531; Pearl, HW-28739; Bainard, HW-40694; Richman, HW-45070. See also: Richman, HW-37694.

52. DuPont, Operation, HAN-73214, Book 11, pp. 76-77, 110; Hanford Eengineer Works, OUT-1492, p. 88; Kidder and Jordan, HW-3-2224. 
53. Parker, HW-20959; Healy, HW-24578. (Note: For further discussion of the problems associated with radionuclides and Columbia River fish, see Gerber, On The Home Front, Chapter 5.)

54. Starkebaum, HW-33698; Conley, HW-24055; deHalas and Gay, HW-34821; Hardin, HW-36021; Hardin, HW-38808; Hardin, HW-40703; Matsumoto, HW-43830; Koop, HW-50601. (Note: For further discussion of Hanford policy regarding operating purges, see Gerber, On the Home Front. Chapter 5.)

55. Trumble, HW-44708, Vols. 1 and 2; Russ, HW-30401, Vol. 1; Young, HW-56230RD; IPD, HW-74094, Vol. 3; Stainken, HW-35589.

56. Carbon and Gilbert, HW-37437.

57. Greager, HW-37033; Talbott, HW-37304.

58. Trumble, HW-44708, Vols. 1 and 2; Baker and McLenegan, HW-43937; Lyons, HW-40363-Del.

59. Renn, HAN-65347; Dickeman, HW-65580; Trumble, HW-61580; DeNeal, DUN-6888; Quinn, HAN-73578; Reid, HW-57497. (Note: For a complete discussion of fuel fabrication changes and improvements at the Hanford Site, see Gerber, WHC-MR-0388.)

60. Bainard, HW-49777; Heacock, HW-60596; Nilson, HW-63924.

61. Deichman, HW-67741-Del; Dickeman, HW-65580; Bainard, HW-49777; Travis and Bloch, HAN-71403; Upson, HW-63562; CETO, HW-61197 RD; Young, HW-65760; Young, HW-66468; Curtiss, HW-55819.

62. McLenegan, HW-62729; Corley, HW-61206; Watson, Fox, Harrison, Kempf, and Reinig, HW-65269; Trumble, HW-67131; Kratzer, HW-67491; Curtiss, Fullmer, and Gilbert, HW-67491; Jones, HW-62861; Robbins, HW-66363.

63. Trumble, HW-67131; Heacock and Jones, HW-SA-2287; IPD, "Acceptance of Completed Project...," November 8, 1961; Jessen, "Physical Completion Notice...," December 15, 1961.

64. IPD, "IPD Radiation Exposure Reduction Program," October 20, 1958; Walker, HW-50351-Del; Faught, "Reevaluation of the Justification...," February 13, 1958; Porter, "Request for Mechanical Development...," November 17, 1958; DeNeal, DUN-6888.

65. IPD, "Project Proposal...Project CG-786," December 2, 1957; Murray, "Construction Completion and Cost Closing Statement," February 13, 1959; G.E. Hanford Company, "Project Proposal, Revision 1...Project CG-707," June 21, 1957; IPD, "Semi-Monthly Project Report," November 1958; IPD, "Project No. CGI-806...," June 15, 1961; Astley, "Pressure Monitor System Repair and Modification," March 28, 1962; Copeland, HW-63298; Greringer, "Improvements to Gamma Monitor 
System...," June 27, 1960; Greninger, "Transmittal Letter...," September 6, 1961; IPD, "Acceptance of Completed Project," May 1, 1963; Corlett, "Fuel Rupture Monitor System," July 1, 1964; Astley, "Project CGI-904...," July 10, 1964; Simsen, IP64-15; Hermann, HW-78840; Lyons, DUN-812; DUN, "Acceptance of Completed Project CGI-143 (105-8)," September 30, 1966; Lyons, RL-REA-676; Jessen, "Physical Completion Notice...," April 10, 1967.

66. "Hanford to Cut Back in 1965," January 8, 1964.

67. Hall and Jerman, HW-63653; Washington State Department of Health, CIC-161754; Spies, CIC-161740; Spies, CIC-161731; Dworsky, CIC-161744; Silker, HW-56366; McCormack and Schwendiman, HW-61325; Foster and Junkins, HW-63654; Healy, HW-60529; Geier, DUN-1906. (Note: A curie is a measure of radioactivity defined as the amount of radioactive material that has an activity of $3.7 \times 10^{10}$ disintegrations per second. About 14 curies of radioactivity were released to the atmosphere in the 1979 incident at Three Mile Island, Pennsylvania. For a more complete discussion of the effects of radionuclides in the Columbia River, see Gerber, On the Home Front, Chapter 5.)

68. Herde, HW-3-5501; Coopey, HW-11662; Olson and Foster, HW-20055; Schiffman, HW-72107; Parker, HW-32809. (Note: This is a partial listing. There are many similar studies. For a complete discussion of the role of reactor effluent in the Columbia River, see Gerber, On the Home Front, chapter 5.)

69. Foster, HW-49713; Foster, HW-54858; Junkins, HW-68096; Hall, HW-65733-RD; Hall and Jerman, HW-64517; Hall and Jerman, HW-63653.

70. Silker, HW-56366. See also: HLO and IPD, HW-70526.

71. Rieck, HW-72215; HLO and IPD, HW-70526; Ballowe, DUN-2231.

72. HLO and IPD, HW-70526; Geier and VanWormer, HW-75609; Geier, HW-75949; Geier, HW-83775; Silker, BNWL-CC-1055; Geier, DUN-3935.72.22

73. Honstead, HW-39465; Fuquay, HW-40371.

74. Ballowe, DUN-2231.

75. Hanford Atomic Products Operation, HW-69000, Vol. I, p. 2.0-6; Stapp and Marceau, BHI-00627, Rev 0, p. 23.

76. Hanford Atomic Products Operation, HW-69000, Vol. I, pp. 3.7-3-6; Coleman, DUN-7342.

77. Hanford Atomic Products Operation, HW-69000, Vol. I, pp. 3.6-2-8; Stapp and Marceau, BHI-0627, Rev. 0, Appendix C.

78. Corbitt and Geier, DUN-5200-RD. 
79. Erickson, UNI-1437, Rev. 2, pp. 5-6, 10, V-1; Scott, UNI-1960, pp. 1-3, 13-17; Newby and Marshall, UNI-2109; Lyon, UNI-2110; Nelson, UNI-3422; Nelson, UNI-3329; Zaloudek and Ruff, UNI-3653 (PNL-5924); Zaloudek and Ruff, UNI-38994 (PNL-5930); Lee, UNI-4193; Nelson, UNI-4191 Rev. 1; Alzheimer and Gonzalez, UNI-4285; Martek, UNI-4263; Lyon, UNI-1986; Cummings, UNI-2063; Rainey, UNI-2182; Conn, UNI-2227 Rev. 1; DeMaria, UNI-3481 Rev 1; Shoemaker and Fuller, UNI-21016; Reeves, UNI-610 Rev. 1; Lechelt, UNI-2925; Lattin, UNI-3333; Rasmussen, UNI-3583; Stauch, UNI-4210; Linschooten, UNI-4148; Pope, UNI-4239; Smith, UNI-4253; Sullivan, UNI-4225.

80. Hanford Engineer Works, HW-10475-B, pp. 910-919. (Note: The exact fuel storage times used in World War II are not known. Following the war, storage times lengthened in order to allow for additional decay (stabilization) of radioisotopes such as lodine 131.)

81. Foskett, HW-18208; Stark, HW-22824.

82. Watson, Brendel and Shields, WHCOEP-0477.

83. . Harrison, DUN-7711.

84. Nelson, UNI-2046.

85. DuPont, IN-6263.

86. DuPont, Construction, HAN-10970, Vol. III, pp. 861-919.

87. DuPont, Construction, HAN-10970, Vol. Ill, pp. 905-908; Gerber, WHC-MR-0452.

88. DuPont, Construction, HAN-10970, Vol. III, pp. 913-915; Gerber, WHC-MR-0452.

89. DuPont, Construction, HAN-10970, Vol. III, pp. 917-919; Gerber, WHC-MR-0452.

90. Hanford Engineer Works, HW-10475-C; Stoller and Richards, Reactor Handbook, 2nd ed. pp. 227-234.

91. Hanford Engineer Works, HW-10475-C.

92. Hanford Engineer Works, HW-10475, Section C; Swartout, HW-3-2801.

93. DuPont, Operation, HAN-73214, Book 12, p. 75.

94. DuPont, Operation, HAN-73214, Book 12, p. 76; G.E. Hanford Co., "Property Disposal Report," \#54-217, May 23, 1954.

95. DuPont, Operation, HAN-73214, Book 12, p. 145.

96. DuPont, Operation, HAN-73214, Book 12, p. 49.

97. DuPont, Operation, HAN-73214, Book 12, p. 174. 
98. G.E. Hanford Co., HW-22201-DEL, pp. 7, 22-23.

99. Felts, HW-33093-RD; GE Hanford Co., HW-34000-DEL, pp. 23-24; Felts, HW-35596; GE Hanford Co., HW-50000-DEL, pp. 23-24; GE Hanford Co., HW-54000-DEL, p. 31.

100. G.E. Hanford Co., HW-18700 DEL; Carr, HW-24800-105, pp. 2-21.

101. G.E. Hanford Co., HW-18700 DEL; Jenkins and Foster, RHO-CD-505-RD-DEL; Harmon, "Project CA-535..."; Sloat, HW-27796; Rohrmann and Ludlow, HW-27968; G.E. Hanford Co., HW-39900 DEL, p. 20; Falk, HW-42687; Lyneis, "Construction Work Authorization, project CG-692..."; Bergdahl, "Physical Completion Notice, Project CG-692"; Yoder, "233-S Information Manual"; Investigating Committee, BNWL-10011 DEL, Part I, Sections I-II.

102. Carr, HW-24800-105, pp. 2-21.

103. Carr, HW-24800-105, pp. 22-23; Courtney and Clark, pp. 48-49.

104. Carr, HW-24800-105, pp. 40-42; GE Hanford Co., HW-30000-DEL, pp. 29-30.

105. Carr, HW-24800-105, pp. 26-34.

106. Carr, HW-24800-105, pp. 34-54; GE Hanford Co., HW-34000-DEL, pp. 23-24.

107. GE Hanford Co., HW-50000-DEL, pp. 23-24; GE Hanford Co., HW-54000-DEL, pp. 25-27; Tomlinson, HW-60892-RD; Platt and Tomlinson, HW-46138; GE Hanford Co., HW-60000-DEL, pp. 18-19.

108. GE Hanford Co., HW-64000-DEL, pp. 32-35; GE Hanford Co., HW-67700-DEL, pp. 11, 22; GE Hanford Co., HW-72000-DEL, p. 12; GE Hanford Co., HW-75700-DEL, pp. 4-5, 13, 20; Duckworth, HW-77678; GE Hanford Co., HW-82330-DEL, p. 5, 29; Gydesen, PNWD-2017 HEDR; IPD and CPD, HW-78100, pp. 5-6, 26; Finch, HW-64162; Roemer, WHC-SD-HS-SAR-001, Rev. 5. p. B-7.

109. Harmon, HW-84317; Smith, HW-65979.

110. Roemer, WHC-SD-HS-SAR-001, Rev. 5, Appendix B; Clemans, WHC-CM-5-20.

111. Christensen, Alford, Kelley, Schmidt and Smith, ARH-CD-450; U.S. ERDA, ERDA-1538; NAS, "Radioactive Wastes at the Hanford Reservation...".

112. Cahow, RHO-CD-704; Reberger, RHO-CD-1418.

113. Finch, ARH-2291; Raile, RHO-CD-1262-CDR; Danch and Schroeder, RHO-CD-268; Shoemaker, RHO-CD-1259-FDC; Parnell, RHO-CD-282, Rev. 2; Prosk, SD-CP-SAR-006; Vitro Engineering Corporation, RHO-CD-1269-CDR; Van Meter, RHO-CD-1349; Braun Hanford Company, B-379-C1; Prosk, SC-HS-SAR-013; Dahlke, SD-CP-DCR-001. 
114. Murphy, RHO IL 37400-86-124; Bowman, RHO IL 65940-85-616; Nolan and Lorenzini, "MOA: Use of the 305 Building...," 1985; Jacobs, WHC IM 12223-88-133; Schofield, WHC IM 14300-99-110.

115. Cahow, RHO-CD-704; Roemer, WHC-SD-HS-SAR-001, Rev. 5, Section 1; "PUREX Resumes Operation," April 27, 1988; "Hanford's PUREX Plant Restarts After Year Closed," December 18, 1989; "Watkins Orders Standby for PUREX," October 17. 1990; Mueller, "PUREX Ready for Next Step," December 14, 1992.

116. Tomlinson, HW-60892-RD; Platt and Tomlinson, HW-46138; GE Hanford Co., HW-60000-DEL, pp. 18-19.

117. Bruns, HW-67674; Kendall, Lambert and Nelson, HW-79665; CPD, RL-SEP-650; Harmon, HW-84317; Denton, "Operating History...", PUREX Process Subsection, ISO-419.

118. Hewlett and Duncan, WASH-1512; U.S. AEC, AEC-1140; Streid, HM-253.

119. GE Hanford Co., HW-23982 DEL, pp. A-1, F-1, Fb-6; G.E. Hanford Co., HW-2480090, pp. 13, 18; Bell, HW-23232, pp. 10-14; G.E. Hanford Co., HW-24800-36, p. 23.

120. GE Hanford Co., HW-26946 DEL, pp. Ff-5, Ff-12; G.E. Hanford Co., HW-27288 DEL, pp. Fg-7, Fg-18; G.E. Hanford Co., HW-27624 DEL, pp. Ed-9, Ff-6, Fg-7, Fg-16, Fg-19-20; G.E. Hanford Co., HW-27932 DEL, pp. Ed-10, F-4, Ff-10, Fg-6, Fg-14, Fg-16, Fg-19; Helgeson, HW-28918; G.E. Hanford Co., HW-28267 DEL, pp. Ed-12, Ff-10-11, Fg-19; G.E. Hanford Co., HW-28576 DEL, pp. Ed-10, F-4, Ff-6, Ff-10, Fg-7, Fg-16; G.E. Hanford Co., HW-29513 DEL, p. Ed-10; Shaw, Directive No. HW-304; Shaw, Directive No. HW-305.

121. GE Hanford Co., HW-30724 DEL, pp. F-4, Ff-9, Fg-12-13; G.E. Hanford Co., HW-31006 DEL, pp. Ed-9, F-3, Fc-17-18, Ff-8, Fg-12; G.E. Hanford Co.. HW-31267 DEL, pp. Ed-9, F-4, Fc-20, Ff-8, Fg-12; G.E. Hanford Co., HW-31734 DEL, pp. F-3, Fc-19, Ff-9; Shaw, Directive No. HW-304, Modifications \#1 and \#2; G.E. Hanford Co., HW-31964 DEL, pp. Ed-5, FC-19, Ff-7, Fg-12; G.E. Hanford Co., HW-32317 DEL, pp. Fc-14, Ff-9, Fg-13; G.E. Hanford Co., HW-32624 DEL, pp. Fc-17, Ff-8, Fg-13; G.E. Hanford Co., HW-32889 DEL, pp. Fg-11-12; G.E. Hanford Co., HW-33200 DEL, p. Fg-12; G.E. Hanford Co., HW-33585 DEL, p. Fg-13; G.E. Hanford Co., HW-33962 DEL, pp. Fc-14, Fg-11; G.E. Hanford Co., HW-34147 DEL, p. Fg-11; Beede, HW-45700; Baker, HW-52395.

122. Thomas, Directive No., HW-426; Travis, Directive No. HW-426, Modifications \#1, \#2 and \#3; Fritz, HWS-6250; Travis, Directive No. HW-427, and Modifications \#1, \#2, \#3, and \#4; Operation Managers, HW-48132 DEL, pp, A-5, E-7, H-6-7; Operation Managers, HW-51802 DEL, pp. E-10, H-8-9; Operation Managers, HW-54319 DEL, pp. E-9, H-7; G.E. Hanford Co., "Acceptance of Completed Project, HW-427, Mod. \#3"; Operation Managers, HW-63313 DEL, p. E-3; Ciccarelli, HW-58258; Operation Managers, HW-66646 DEL, p. D-2; Operation Managers, HW-63706 DEL, pp. D-2, F-5. 
123. Sloat, RL-SEP-589; Operations Managers, RL-SEP-913, pp. 5-6, D-1; U.S. DOE, "Historical Release Report for the Rocky Flats Plant;" Operations Managers, HW-81620, pp. 5-6, D-1-2; Operation Managers, HW-82089 DEL, pp. D-1-2; Operation Managers, HW-82526 DEL, pp. 5-6; Operation Managers, HW-83102 DEL, pp. 5-6, D-1-2; Operation Managers, RL-SEP-197 DEL, pp. 5-6, D-1; Operation Managers, RL-SEP-618 DEL, pp. 5-6, D-1-2; Operation Managers, RL-SEP-837 DEL, pp. 5-6, D-1-2; Walser and Lyon, RL-SEP-249 RD; Section Managers, ISO-89 DEL, p. D-2; Section Managers, ISO-143 DEL, pp. D-1-2, Section Managers, ISO-210 DEL, p. D-2; Walser and Lyon, HW-80356 RD, pp. 31, 35, 38.

124. Warren, HW-76496; Kendall, HW-81542; Braden, RL-SEP-368; Gifford, "Plutonium From Nuclear Fuel Services;" Borgeson and Nelson, RL-SEP-590; Finch, RL-SEP-726; Hill and Tomlinson, RL-SEP-871, pp. 36-37; Operation Managers, RL-SEP-913, pp. 5-6; Section Managers, ISO-276 DEL, p. D-1.

125. Hill and Tomlinson, RL-SEP-871, pp. 36-37; Operation Managers, RL-SEP-913, pp. 5-6; Section Managers, ISO-276 DEL, p. D-1; Shaw, "Physical Completion Notice...," May 26, 1966; Section Managers, ISO-315, p. F-1; Section Managers, ISO-365 DEL, p. E-2; Walser and Ly'on, HW-80356 RD, p. 57; Walser and Lyon, RL-SEP-249 RD; Hewlett and Holl, Atoms for Peace and War, p. 320-21; Operation Managers, RL-SEP-837, p. D-1; Operation Managers, RL-SEP-197, pp. D-1-2. 


\section{BIBLIOGRAPHY}

AEC-GE Study Group for the Economic Development of Richland, "Catalog of Hanford Buildings and Facilities," GEH-26434 (Richland, Washington: U.S. Atomic Energy Commission, April 1964), Vols. I-IV.

Alexander, W. K., "Technical Activities Report - Heat, Water and Mechanical Studies, December 1951," HW-23153 (Richland, Washington: G.E. Hanford Co., January 3, 1952).

Alzheimer, J. M., and Gonzalez, L. M., "Ciontrolled Development Plan for Development of N Reactor Horizontal Control Rod Channel Profiling Equipment," UNI-4285 (Richland, Washington United Nuclear Industries, Inc., February 17, 1987).

Amy, G. O., "Process Test - MR-1: Charge-Discharge Without Crossheader Valving," HW-24492 (Richland, Washington: G.E. Hanford Co., May 15, 1952).

Astley, E. R., "Pressure Monitor Repair and Modification, 105-C" Letter to W. Seeburger (Richland, Washington: G.E. Hanford Co., March 28, 1962).

Astley, E. R., "Project CGI-904: Improvements of Gamma Monitor Systems, 105-B, C, D. DR, F, and H Buildings," Letter to J.V. Loftus (Richland, Washington: G.E. Hanford Co., July 24, 1964).

Bainard, W. D., "Future Acid, Silicate and Silica Requirements - 100 Areas," HW-40694 (Richland, Washington: G.E. Hanford Co., December 30, 1955).

Bainard, W. D., "100-B Area Flow Analysis," HW-49777 (Richland, Washington: G.E. Hanford Co., June 1, 1957).

Baker, D. S., and McLenegan, D. W., "Effect of Increased Electric Loads on Primary Substation Equipment in 100-B, C, D, DR, F, and H Areas," HW-43937 (Richland, Washington: G.E. Hanford Co., July 5, 1956).

Baker, R. G., "Project Proposal, Revision :2: Improved task I and Task II Facilities, 234-5," HW-52395 (Richland, Washington: G.E. Hanford Co., September 9, 1957).

Ballowe, J. W., "Summary Report: Alternate Methods of Reactor Effluent Treatment and Disposal," DUN-2231 (Richland, Washington: Douglas United Nuclear, Inc., March 22, 1967).

Batch, J. M., and Toyoda, K. G., "Description of the Thermal Hydraulics Laboratory at Hanford," HW-65722 (Richland, Washington: G.E. Hanford Co., June 20, 1960).

Beede, R. L., "Continuous Plutonium (IV) Oxalate Precipitation, Filtration and Calcination Process," HW-45700 (Richland, Washington: G.E. Hanford Co., September 27, 1956). 
Bell, R. S. "Synopsis of Scheduling for the Completion of the RMA Line," HW-23232 (Richland, Washington: G.E. Hanford Co., January 4, 1952).

Bell, E. S., "Project Proposal: Projection Fuel Element Modifications, 313 Building, Rev. 1A," HW-68662 (Richland, Washington: Hanford Atomic Products Operation, March 20, 1961).

Bergdahl, C. R., "Physical Completion Notice, Project CG-692," HW-400 (Richland, Washington: G.E. Hanford Co., April 18, 1958).

Bixler, R. B., "300 Area Reports, Health Instruments," (Richland, Washington: Hanford Engineer Works, Monthly: August 1946 - April 1948).

Bixler, R. B., "Special Hazards Incident Investigations, Class I, No. 85, 86, and 87," (Richland, Washington: Hanford Engineer Works, 1948).

Borgeson, M. E., and Nelson, D. C., "Design Criteria: Plutonium Buy-Back Facility," RL-SEP-590 (Richland, Washington: G.E. Hanford Co., September 3, 1965).

Borgmier, B. J., "Bibliography on Slug Failures Occurring in the Hanford Production Reactors," HW-21199 (Richland, Washington: G.E. Hanford Co., May 25, 1954).

Bowman, M. W., "Thorium, Phosphorus and Titanium Impurities in the Oxide Product," RHO-IL-65940-85-616 (Richland, Washington Rockwell Hanford Operations, December 27, 1985).

Braden, D. E., "Plutonium Blending Facility - Z-Plant, FY-1967 Budget facility Description," RL-SEP-368 (Richland, Washington: G.E. Hanford Co., March 31, 1965).

Brandt, H. L., and H. P. Kraemer, "Removal of the Compound Layer from Decanned Hanford Uranium Slugs by the Use of Sodium Hydroxide," HW-28282 (Richland, Washington: Hanford Atomic Products Operation, May 15, 1953).

Brandt, H. L., "Removal of the Compound Layer from Decanned Hanford Uranium Slugs by the Use of Sodium Hydroxide," HW-29871 (Richland, Washington: Hanford Atomic Products Operation, November 5, 1953).

Braun Hanford Co., "Construction Specifications for PUREX White Room Filtration System," B-379-2 (Richland, Washington Braun Hanford Co., January 15, 1982).

Bruns, L. E., "Flowsheet for Separation of Plutonium from Thorium and Uranium," HW-67674 (Richland, Washington: G.E. Hanford Co., December 7, 1960).

Bupp, L. P., "Provision for Activated Silica at 183-8," HW-28531 (Richland, Washington: G.E. Hanford Co., June 26, 1953).

Cahow, D. L., "PUREX Oxide Conversion Facility Preliminary Safety Analysis Report," RHO-CD-704 (Richland, Washington Rockwell Hanford Operations, July 1979). 
Call, R. L., and Rector, J. H., "Production Test No., 105-565-A: Horizontal Rode Conversion - Old Piles," HW-30863 (Richland, Washington: G.E. Hanford Co., February 15, 1954l.

Carbon, M. W., and Fryar, R. M., "Pile Modifications Resulting in Increased Power Levels," HW-20425 (Richland, Washington: G.E. Hanford Co., July 10, 1951).

Carbon, M. W., and Gilbert, W. D., "Tube Power Limits - Past, Present and Future," HW-37437 (Richland, Washington: G.E. Hanford Co., May 31, 1955).

Carlson, P. A., and Trumble, R. E., "Prelirninary Hazards Review Operational Charge Discharge For Hanford Reactors," HW-62471 (Richland, Washington: G.E. Hanford Co., October 26, 1959).

Carr, P. S., "Completion Report, Expansion of 200 Area Facilities," HW-24800-105 (also HAN-69940) (Richland, Washington: G.E. Hanford Co., September 1958).

Chemical Effluents Technology Operation (CETO), "Chemical Effluents Technology Waste Disposal Investigations - April, May, June 1959," HW-61197-RD (Richland, Washington: G.E. Hanford Co., July 22, 1959).

Chemical Processing Department (CPD), "Process Bases and Specifications, Thorium U-233 Separations at the PUREX Plant," RL-SEP-650 (Richland, Washington: G.E. Hanford Co., July 26,1965 ).

Ciccarelli, R. A., "Radiography Facility - Design Basis - Project CG-811," HW-58258 (Richland, Washington: G.E. Hanford Co., January 6, 1959).

Clemans, W. H., "Manufacturing Process Specifications for N Reactor Fuel," WHC-CM-5-20 (formerly DUN-5601) (Richland, Washington: Westinghouse Hanford Co., March 1988).

Cole, J. B., "Final Report: Production Test 105-389-P: Graphite Sample Boring from Process Channels," HW-21659 (Richland, Washington: G.E. Hanford Co., July 10, 1951).

Coleman, G. C., "Investigation of N React:or Scram of September 30, 1970," DUN-7342 (Richland, Washington Douglas United Nuclear, Inc., 1970).

Conley, W. R., Final Report, Production Test No. 105-214-P: Silica Feed Elimination," HW-15943 (Richland, Washington: G.E. Hanford Co., February 1, 1950).

Conley, W. R., "A Review of Water Treatment Technology as Applied in the 100 Areas Hanford Works," HW-20342 (Richland, Washington: G.E. Hanford Co., January 23, 1951).

Conley, W. R., "Production Test - 105-3-MR: The Use of Dicalite Diatomaceous Earth as a Purge Material in the 100 Areas," HW-24055 (Richland, Washington: G.E. Hanford Co., April 8, 1952). 
Conn, K. R., "Technical Criteria - Project H-601G Replacement Valves," UNI-2227 Rev. 1 (Richland, Washington United Nuclear Industries, Inc., February 18, 1983).

Coopey, R. W., "The Accumulation of Radioactivity as Shown by a Limnological Study of the Columbia River in the Vicinity of Hanford Works," HW-11662 (Richland, Washington: G.E. Hanford Co., November 12, 1948).

Copeland, H. C., "Scope Report: Improvement of Gamma Monitor Systems for 105-B, C, D, DR, F, \& H," HW-63298 (Richland, Washington: G.E. Hanford Co., February 17, 1960).

Corbitt, C. D., and Geier, R. G., "Waste Management Plan," DUN-5200 RD (Richland, Washington Douglas United Nuclear, Inc., December 9, 1968).

Corlett, R. F., "Investigation of 300 Area Slug Pickling Operation," HW-38332 (Richland, Washington: Hanford Atomic Products Operation, August 3, 1955).

Corlett, R. F., "Fuel Rupture Monitor System," Letter to J.W. Green (Richland, Washington: G.E. Hanford Co., July 1, 1964).

Corley, J. P., "Effluent System Modifications - 100 B/C," HW-61206 (Richland, Washington: G.E. Hanford Co., October 7, 1959).

Cummings, J. E., "Production Tests N-520, V-19/V-3 Split Flow Testing," UNI-2063 (Richland, Washington United Nuclear Industries, Inc., June 2, 1982).

Curtiss, D. H., "Graphite Radiation Damage as a Reactor Operational Problem," HW-55819 (Richland, Washington: G.E. Hanford Co., April 14, 1958).

Curtiss, D. H., Fullmer, G. C., and Gilbert, W. D., "Reactor Components Study," HW-57222 (Richland, Washington: G.E. Harıford Co., August 25, 1958).

Dahlke, H. J., "PUREX Seismic Upgrades, Backup Analyses," SD-CP-DCR-001 (Richland, Washington Rockwell Hanford Operations, January 15, 1982).

Dalrymple, R. S., "Evaluation of Anodic Films on Process Tube Exteriors," HW-26395 (Richland, Washington: G.E. Hanford Co., March 4, 1953).

Danch, D. A., and Schroeder, B. K., "Fire Protection for PUREX Main Ventilation Filters," RHO-CD-268 (Richland, Washington Rockwell Hanford Operations, May 1, 1978).

de Halas, D. R., and Gay, R. H., "Reduction of Rear Face Zn65 Activity," HW-34821

(Richland, Washington: G.E. Hanford Co., January 31, 1955).

Deichman, J. L., "Causes of Reactor Shutdowns," HW-67741-Del (Richland, Washington: G.E. Hanford Co., December 19, 1960). 
DeMaria, L. C., "Project Management Plan, V-11 Valve Rehabilitation Project H-680," UNI-2481, Rev. 1 (Richland, Washington United Nuclear Industries, Inc., December 19, 1986).

DeMers, A. E., "Final Status of C-Reactor Test Holes," Memo to File (Richland, Washington Douglas United Nuclear, Inc., November 18, 1969).

DeNeal, D. L., "Historical Events - Single Pass Reactors and Fuel Fabrication," DUN-6888 (Richland, Washington: Douglas United Nuclear, Inc., April 10, 1970).

Denton, L. E., "Operating History - Thoria Wafer Program" (Richland, Washington Douglas United Nuclear, Inc., October 15, 1969).

Dickeman, R. L., "Safety Experience - Reactor and Critical Facilities, Calendar Year 1959," HW-65580 (Richland, Washington: G.E. Hanford Co., June 6, 1960).

Douglas United Nuclear, Inc. (DUN), "Acceptance of Completed Project, No. CGI-143" (105-B) (Richland, Washington Douglas United Nuclear, Inc., September 30, 1966).

Drumheller, K., "Equipment Design Scope Conversion of 313 to I \& E Production," HW-47887 (Richland, Washington: Hanford Atomic Products Operation, February 11, 1957).

Drumheller, K., "Design Criteria and Specifications for New Fuel Cladding Facility Building 333 - 300 Area," HWS-6797 (Richland, Washington: Hanford Atomic Products Operation, July 6, 1959).

Duckworth, J. P., "PUREX Neptunium Recovery and Purification Information Manual," HW-77678 (Richland, Washington: G.E. hanford Co., April 1, 1963).

DuPont Corp., "Completion Report, Manhattan District, Hanford Engineer Work, TNX Plant," (Wilmington, DE: E.I. DuPont de Nemours and Co., April 30, 1945).

DuPont Corp., "Design and Procurement History of Hanford Engineer Works and Clinton Semi-Works," IN-6263 (Wilmington, DE: E.I. DuPont de Nemours and Co., 1945).

DuPont Corp., Construction of Hanford Engineer Works: History of the Project, HAN-10970 (Wilmington, DE: E.I. DuPont de Nemours and Co., 1946).

DuPont Corp., Operation of Hanford Engineer Works, HAN-73214 (Wilmington, DE: E. I. DuPont de Nemours \& Co., 1946).

Durum, W. H., and R. W. Chamberlin, "300 Area Reports, Health Instruments," (Richland, Washington: Hanford Engineer Works, Monthly: June 1945 - July 1946).

Dworsky, L. B., "Pollution of the Columbia River Resulting from the Atomic Energy Commission's Hanford Atomic Works, Richland, Washington," CIC-161744 (Portland, OR: U. S. Public Health Service, January 11, 1962). 
Erickson, G. L., "Development and Quality Assurance Instructions and Procedures for Systems and Equipment Development Section," UNI-1437 Rev. 2 (Richland, Washington United Nuclear Industries, Inc., September 1, 1982).

Etheridge, E. L.. "Preliminary Test Results of Unfiltered River Water as a Pile Coolant," HW-32664 (Richland, Washington: G.E. Hariford Co., August 4, 1954).

Falk, C. F., " "Project Proposal: Modifications to REDOX Plutonium Concentration Building 233-S (Project CG-692)," HW-42687 (Richland, Washington: G.E. Hanford Co., April 30 , 1956).

Faught, M. L., "Reevaluation of the Justification for Ball $3 X$ Electrical Modifications, 105-B, D, DR, F and H" (Richland, Washington: G.E. Hanford Co., February 13, 1958).

Felts, W. R., "Design Criteria - Part I: "B" Plant Reactivation - 4X Program," HW-33093-RD (Richland, Washington GE. Hanford Co., September 24, 1954).

Felts, W. R., "Scope Review - 4X Program "B" and "T" Plants - Project CG-603," HW-35596 (Richland, Washington: G.E. Hariford Co., March 2, 1955).

Finch, L. W., "Preliminary Project Proposal - Expansion to 4.0 Capacity Factor - PUREX," HW-64162 (Richland, Washington: G.E. Hariford Co., April 4, 1960).

Finch, L. W., "Project Proposal: Plutonium Buy-Back Facility - 234-5 Building (Project CGC-180)," RL-SEP-726 (Richland, Washington: G.E. Hanford Co., September 28, 1965).

Finch, L. W., "Project Proposal: PUREX Plant Fire Protection Improvements (Project HCP-668)," ARH-2291 (Richland, Washington: Atlantic Richfield Hanford Co., March 23, 1972).

Foskett, E. A., "Storage Problems in the 200 North Area," HW-18208 (Richland, Washington: G.E. Hanford Co., June 30, 1950).

Foster, R. F., "Recommended Limit on Addition of Dichromate to the Columbia River," HW-49713 (Richland, Washington: G.E. Haniford Co., April 17, 1957).

Foster, R. F., "The Effect on Fish of Increasing the Temperature of the Columbia River," HW-54858 (Richland, Washington: G.E. Hanford Co., March 14, 1958).

Foster, R. F., and Junkins, R. L., "Off Project Exposure from Hanford Reactor Effluent," HW-63654 (Richland, Washington: G.E. Hanford Co., February 1, 1960).

Fox, J. M., "Design Scope Activated Silica-Alum Water Treatment Facilities Reactor Areas B, D, F, DR and H," HW-25345 (Richland, Washington: G.E. Hanford Co., July 25, 1952).

Fritz, J. R., "Specifications for RMC Button Line Installation in 234-5 Building," HWS-6250 (Richland, Washington: G.E. Hanford Co., June 18, 1958). 
Fry, W. E., "Production of Polonium 210, Thulium 170, and Iridium 192 in a Hanford Production Pile," HW-43749 (Richland, Washington: G.E. Hanford Co., June 14, 1956).

Fryar, R. M., "Technical Activities Report Water Studies," HW-23361 (Richland, Washington: G.E. Hanford Co., January 1952).

Fuquay, J. J., "A Preliminary Appraisal of Meteorological Aspects of Disposal of Reactor Effluent through an Inland Lake System," HW-40371 (Richland, Washington: G.E. Hanford Co., 1956).

G.E. Hanford Co., "Hanford Engineer Works Monthly Report, August 1947," HW-07504 (Richland, Washington: G.E. Hanford Co., September 17, 1947).

G.E. Hanford Co., "REDOX Technical Manual," HW-18700 DEL (Richland, Washington: G.E. Hanford Co., July 10, 1951 ).

G.E. Hanford Co., "Hanford Works Monthly Report for March 1952," HW-23982 DEL (Richland, Washington: G.E. Hanford Co., April 18, 1952).

G.E. Hanford Co., "Hanford Works Monthly Report for January 1953," HW-26946 DEL (Richland, Washington: G.E. Hanford Co., February 24, 1953).

G.E. Hanford Co., "Hanford Works Monthly Report for February 1953," HW-27288 DEL (Richland, Washington: G.E. Hanford Co.., March 18, 1953).

G.E. Hanford Co., "Hanford Works Monthly Report for March 1953," HW-27624 DEL (Richland, Washington: G.E. Hanford Co., April 22, 1953).

G.E. Hanford Co., "Hanford Works Monthly Report for April 1953," HW-27932 DEL (Richland, Washington: G.E. Hanford Co., May 20, 1953).

G.E. Hanford Co., "Hanford Works Monthly Report for May 1953," HW-28267 DEL (Richland, Washington: G.E. Hanford Co., June 19, 1953).

G.E. Hanford Co., "Hanford Works Monthly Report for June 1953," HW-28576 DEL (Richland, Washington: G.E. Hanford Co., July 22, 1953).

G.E. Hanford Co., "Design and Construction History, Project C-198, 234-5 Building Program, Phases II and III," HW-24800-36 (Richland, Washington: G.E. Hanford Co., August 1953).

G.E. Hanford Co., "Hanford Works Monthly Report for September 1953," HW-29513 DEL (Richland, Washington: G.E. Hanford Co., October 21, 1953 ).

G.E. Hanford Co., "Hanford Works Monthly Report for January 1954," HW-30724 DEL (Richland, Washington: G.E. Hanford Co., February 25, 1954).

G.E. Hanford Co., "Hanford Works Monthly Report for February 1954," HW-31006 DEL (Richland, Washington: G.E. Hanford Co., March 23, 1954). 
G.E. Hanford Co., "Hanford Works Monthly Report for March 1954," HW-31267 DEL (Richland, Washington: G.E. Hanford Co., April 23, 1954).

G.E. Hanford Co., "Design and Construction History, Project C-413 (CG-413) Expansion of 234-5 Building Capacity," HW-24800-90 (Richland, Washington: G.E. Hanford Co., May 1954).

G.E. Hanford Co., "Hanford Works Monthly Report for May 1954," HW-31964 DEL (Richland, Washington: G.E. Hanford Co., June 22, 1954).

G.E. Hanford Co., "Hanford Works Monthly Report for June 1954," HW-32317 DEL (Richland, Washington: G.E. Hanford Co., July 26, 1954).

G.E. Hanford Co., "Hanford Works Monthly Report for July 1954," HW-32624 DEL (Richland, Washington: G.E. Hanford Co., August 20, 1954).

G.E. Hanford Co., "Hanford Works Monthly Report for August 1954," HW-32889 DEL (Richland, Washington: G.E. Hanford Co., September 17, 1954).

G.E. Hanford Co., "Hanford Works Monthly Report for September 1954," HW-33200 DEL (Richland, Washington: G.E. Hanford Co., October 25, 1954).

G.E. Hanford Co., "Hanford Works Monthly Report for October 1954," HW-33585 DEL (Richland, Washington: G.E. Hanford Co., November 24, 1954).

G.E. Hanford Co., "Hanford Works Monthly Report for November 1954," HW-33962 DEL (Richland, Washington: G.E. Hanford Co., December 20, 1954).

G.E. Hanford Co., "Hanford Works Monthly Report for December 1954," HW-34147 DEL (Richland, Washington: G.E. Hanford Co., January 25, 1955).

G.E. Hanford Co., "1954 at Hanford," HW-34000-DEL (Richland, Washington: G.E. Hanford Co., March 15, 1955).

G.E. Hanford Co., "1955 at Hanford," HW-39900-DEL (Richland, Washington: G.E. Hanford Co., March 15, 1956).

G.E. Hanford Co., "1956...Annual Report...1956," HW-50000-DEL (Richland, Washington: G.E. Hanford Co., 1957).

G.E. Hanford Co., "Project Proposal, Revision 1: Improvements to Reactor Nuclear Instrumentation - All Reactors (Project CG-707)" (Richland, Washington: G.E. Hanford Co., June 21, 1957).

G.E. Hanford Co., "1957 Annual Report," HW-54000 DEL (Richland, Washington: G.E. Hanford Co., 1958).

G.E. Hanford Co., "Acceptance of Completed Project, HW-427, Mod. \#3" (Richland, Washington: G.E. Hanford Co., February 25, 1959). 
G.E. Hanford Co., "1958 Annual Report," HW-60000 DEL (Richland, Washington: G.E. Hanford Co., 1959).

G.E. Hanford Co., "Annual Report, 1959," HW-64000 DEL (Richland, Washington: G.E. Hanford Co., April 1, 1960).

G.E. Hanford Co., "Annual Report, 1960," HW-67700 DEL (Richland, Washington: G.E. Hanford Co., March 1, 1961).

G.E. Hanford Co., "Annual Report, 1961," HW-72000 DEL (Richland, Washington: G.E. Hanford Co., 1962).

G.E. Hanford Co., "Annual Report, 1962," HW-75700 DEL (Richland, Washington: G.E. Hanford Co., March 15, 1963).

G.E. Hanford Co., "Annual Report, 1963," HW-82330 DEL (Richland, Washington: G.E. Hanford Co., April, 1964).

G.E. Hanford Co., "Property Disposal Reports/Requests," (various) (Richland, Washington: G.E. Hanford Co., $1954-1965)$.

Gast, P. F., "Report on Additional Production Capacity of Hanford Works: Meeting to Fix Water Requirements," HW-21761 (Richland, Washington: G.E. Hanford Co., July 26,19511 .

Geering, G. T., "Testing of Zircaloy-2-Clard Uranium Seven-Rod Fuel Elements," HW-66267 (Richland, Washington: G.E. Hanford Co., July 5, 1960).

Geier, R. G., and Van Wormer, F. W., "Water Treatment Program - Old Reactors," HW-75609 (Richland, Washington: G.E. Hanford Co., November 19, 1962).

Geier, R. G., "December Monthly Report Contamination Control Columbia River," HW-75949 (Richland, Washington: G.E. Hanford Co., December 20, 1962).

Geier, R. G., "Monthly Report Contamination Control - Columbia River December, 1966," DUN-1906 (Richland, Washington: Douglas United Nuclear, Inc., January 11, 1967).

Geier, R. G., "Quarterly Report Contamination Control - Columbia River October December 1967," DUN-3935 (Richland, Washington: Douglas United Nuclear, Inc., March 11, 1968).

General Electric Co. (GE), and Bouillon and Griffith Co., "Specification for Completion of 313 Building Addition, Alterations and Additions to 303-F and 303-K Buildings, Construction of 311 Facilities, 300 Area," HWS-4955 (Richland, Washington: Hanford Atomic Products Operation, October 15, 1963).

Gerber, M. S., "Past Practices Technical Characterization Report - 300 Area Hanford Site," WHC-MR-0388 (Richland, Washington Westinghouse Hanford Co., December 1992). 
Gerber, M. S., On The Home Front: The Cold War Legacy of the Hanford Nuclear Site (Lincoln, NE: University of Nebraska Press, 1992).

Gerber, M. S., "A Brief History of the PUREX and UO3 Facilities," WHC-MR-0437

(Richland, Washington Westinghouse Hanford Co., November 1993).

Gerber, M. S., "Dramatic Change at T-Plant," WHC-MR-0452 (Richland, Washington Westinghouse Hanford Co., 1994).

Gifford, A. T., "Plutonium From Nuclear Fuel Services," Letter to J.H. Warren (Richland, Washington U.S. Atomic Energy Commission, April 9, 1965).

Gill, S. M., "Coextrusion Process Specifications," HW-69941 (Richland, Washington: Hanford Atomic Products Operation, August 1961).

Greager, O. H., "Safety Experience - Reactor and Critical Facilities," HW-37033 (Richland, Washington: G.E. Hanford Co., June 7, 1955).

Greninger, A. B., "100 Area Water Treatment Specifications," HW-25012 (Richland, Washington: G.E. Hanford Co., July 11, 1952).

Greninger, A. B., "Proposal for Laboratory Facilities in the Technical Center," HW-14110 (Richland, Washington: Hanford Engineer Works, August 19, 1949).

Greninger, A. B., "Improvements to the Gamma Monitor System 105-B, C, D, DR, F and H Buildings," Letter to W.E. Johnson (Richland, Washington: G.E. Hanford Co., June 27, 1960).

Greninger, A. B., "Transmittal Letter for Project Proposal CGI-904, Revision i: Improvements to Gamma Monitor Systems, 105-B, C, D, DR, F, and H Buildings," Letter to W.E. Johnson (Richland, Washington: G.E. Hanford Co., September 6, 1961).

Gydeson, S. P.. "Selected Hanford Reactor and Separations Operating Data for 1960-1964," PNWD-2017 HEDR (Richland, Washington Pacific Northwest Laboratory, September 1992).

Haaga, J. A., "Inspection and Replacement of Van Stone Flanges B, D, and F Piles," HW-09603 (Richland, Washington: G.E. Hanford Co., April 23, 1948).

Hall, R. B., "Waste Disposal Criteria, Existing Reactor Expansion Study," HW-65733-RD (Richland, Washington: G.E. Hanford Co., November 17, 1959).

Hall, R. B., and Jerman, P. C., "Reactor Effluent Water Disposal," HW-63653 (Richland, Washington: G.E. Hanford Co., February 1, 1960).

Hall, R. B., and Jerman, P. C., "Effect of Proposed HAPO Reactor Production Increases on Radioactivity Discharged to the Columbia River," HW-64517 (Richland, Washington: G.E. Hanford Co., March 29, 1960). 
Hanford Atomic Products Operation, "100-N Technical Manual," HW-69000, Vols. I and II (Richland, Washington: G.E. Hanford Co., March 5, 1963).

Hanford Engineer Works, "History of Operations (1 January 1944 to 20 March 1945)," OUT-1462 (Richland, Washington Hanford Engineer Works, 1945).

Hanford Engineer Works, "Technical Manual: Section A - Metal Preparation, Section B Pile, and Section C - Separations," HW-10475-A, B and C DEL (Richland, Washington: Hanford Engineer Works, 1944).

Hanford Laboratories Operation and Irradiation Processing Department, "Monthly Report Contamination Control - Columbia River," HW-70526 (Richland, Washington: G.E. Hanford Co., July 21, 1961).

"Hanford to Cut Back in 1965," in Tri-City Herald (Kennewick, WA), January 8, 1965, p. 1.

"Hanford's PUREX Plant Restarts After Year Closed," in Tri-City Herald, December 18, 1989, p. A3.

Hardin, A. K., "Production Test 105-12-MR: Crossheader Purge with Chromic Acid," HW-36021 (Richland, Washington: G.E. Hanford Co., July 5, 1955).

Hardin, A. K., Interim Report, Production Test MR-105-12: Crossheader Purge with Chromic Acid," HW-38808 (Richland, Washington: G.E. Hanford Co., September 19, 1955).

Hardin, A. K., "In-Pile Defilming of Process Tubes," HW-40703 (Richland, Washington: G.E. Hanford Co., January 6, 1956).

Harlan, and J. C. Williamson, "Process Flow - Accountability - Normal Uranium in 300 Area Using Lead Dip Process," H-3-8391 (Richland, Washington: Hanford Atomic Products Operation, October 5, 1954).

Harmon, M. K., "Project CA-535: REDOX Phase II Expansion, 233-S Building: Description and Use of Facilities," Memo to O.F. Beaulieu (Richland, Washington: G.E. Hanford Co., February 9,1955 ).

Harmon, M. K., "Separation Capability," HW-84317 (Richland, Washington: G.E. Hanford Co., October 8, 1964).

Harrington, C. D., and A. E. Reuhle, eds., Uranium Production Technology (Princeton, NJ: D. Van Nostrand Co., 1959).

Harrison, C. W., "Feasibility Study, Supplemental N Reactor Fuel Storage," DUN-7711 (Richland, Washington Douglas United Nuclear, Inc., July 7, 1971).

Heacock, H. W., "Existing Reactor Expansion Study Basis," HW-60596 (Richland, Washington: G.E. Hanford Co., June 24, 1959). 
Heacock, H.W., and Jones, C. E., "The Hanford Reactor Confinement Program," HW-SA-2287 (Richland, Washington: G.E. Hanford Co., November 10, 1961).

Healy, J. W., "The Effect of Purging During Pile Operation on the Effluent Water," HW-24578 (Richland, Washington: G.E. Hanford Co., May 27, 1952).

Healy, J. W., "Direct Disposal of Reactor Effluent," HW-60529 (Richland, Washington: G.E. Hanford Co., May 27, 1959).

Helgeson, G. L., "Radiation Studies for Task III Design," HW-28918 (Richland, Washington: G.E. Hanford Co., August 26, 1953).

Herde, K., "Radioactivity in various species of Fish from the Columbia and Yakima Rivers," HW-3-5501 (Richland, Washington: G.E. hanford Co., May 14, 1947).

Herrman, B. W., "Preliminary Engineering Study: Linear Power Rate-of-Rise Instrumentation, B, C, D, DR, F, H and KE," HW-78840 (Richland, Washington: G.E. Hanford Co., September 27, 1963).

Hervin, R. L., "Radiation Monitoring Coverage Monthly Reports," (Richland, Washington: Hanford Atomic Products Operation, January - December 1954).

Hewlett, R. G., and Duncan, F., Atomic Shield: A History of the United States Atomic Energy Commission, WASH-1215 (Washington, DC: U.S. Atomic Energy Commission, 1969).

Hewlett, R. G., and Holl, J. M., Atoms for Peace and War: Eisenhower and the Atomic Energy Commission, 1953-1961 (Berkeley: University of California Press, 1989).

Hill, O. F. and Tomlinson, R. E., "Chemical Processing Department, Semiannual Report, Research and Development, May 1, 1965 Through October 31, 1965," RL-SEP-871 (Richland, Washington: G.E. Hanford Co., December 15, 1965).

Hochschild, R., "300 Area Monthly Reports, 1953," HAN-49157-DEL (Richland, Washington: G.E. Hanford Co., February 1953 - January 1954).

Honstead, J. F., "Disposal of Reactor Effluent Through an Inland Lake System," HW-39465 (Richland, Washington: G.E. Hanford Co., October 11, 1955).

Investigating Committee, "Fire Incident, 233-S Facility," BNWL-10011, Part I DEL (Richland, Washington Battelle North West Laboratory, November 1963).

Irradiation Processing Department (IPD), "Project Proposal: Flux Monitor Dual Control System, 105-B, C, D, DR and H (Project CG-786)" (Richland, Washington: G.E. Hanford Co., December 2, 1957).

Irradiation Processing Department, "IPD Radiation Exposure Reduction Program" (Richland, Washington: G.E. Hanford Co., October 20, 1958). 
Irradiation Processing Department, "Semi-Monthly Project Report, October 27, 1958 to November 7, 1958: Improvements to Reactor Nuclear Instrumentation - 100 Areas" (Richland, Washington: G.E. Hanford Co., November 1958).

Irradiation Processing Department, "Hazards Summary Report,". HW-74094, Vols. 1, 2, 3 (Richland, Washington: G.E. Hanford Co., 1963).

Irradiation Processing Department, "Acceptance of Completed Project, CGI-904" (105-C) (Richland, Washington: G.E. Hanford Co., May 1, 1963).

Irradiation Processing Department, "Maintenance Work Forecast, 100-B Area" (Richland, Washington Douglas United Nuclear, Inc., 1966).

Irradiation Processing Department, "Physical Completion Notice: Project No. CGI-806: Nuclear Instrumentation for Reactor Safety and Control - All Areas" (Richland, Washington: G.E. Hanford Co., June 15, 1961).

Irradiation Processing Department, "Acceptance of Completed Project: Reactor Confinement, 105, 117 and 119 - 100-B Area" (Richland, Washington: G.E. Hanford Co., November 8, 1961).

Irradiation Processing Department (IPD) and Chemical Processing Department (CPD), "Hanford Reactor and Separations Facility Advantages," HW-78100 (Richland, Washington: G.E. hanford Co., June 27, 1963).

Jacobs, L.L., "Fast Flux Test Facility Fuel Processing in PUREX -- Possible Conflicts with Potential Head-End Flowsheet Changes," WHC IM 12223-88-133 (Richland, Washington Westinghouse Hanford Co., July 14, 1988).

Janos, A.A., "Project Proposal: Effluent Water Monitoring Improvements - Existing 100 Areas," HW-30083 (Richland, Washington: G.E. Hanford Co., December 7, 1954).

Jenkins, C.E., and Foster, C.B., "Synopsis of REDOX Plant Operations, "RHO-CD-505 RD DEL (Richland, Washington Rockwell hanford Operations, 1978).

Jessen, R.T., "Physical Completion Notice: Project No. CGI-791 (III), Reactor Confinement, Phase III" (Richland, Washington: G.E. Hanford Co., December 15, 1961 ).

Jessen, R.T., "Physical Completion Notice: Project CAl-175: Grounding of 2400-Volt Power Systems, 100-B and D Areas" (Richland, Washington Douglas United Nuclear,Inc., April 10, 1967).

Jones, S. S., "Adequacy of the Old Reactor Backup Cooling Systems," HW-62861 (Richland, Washington: G.E. Hanford Co., December 1, 1959).

Jordan, W. E., "Exit Water Monitoring For Slug-Failure-Operation of System in 105 B," HW-3-1121 (Richland, Washington: Hanford Engineer Works, November 25, 1944). 
Jordan, W. E., and O'Connor, J. J., "Exit Water Monitoring for Slug Jacket Failure," HW-3-1913 (Richland, Washington Hanford Engineer Works, March 3, 1945).

Junkins, R. L., "Columbia River Conditions," HW-68096 (Richland, Washington: G.E. Hanford Co., January 10, 1961).

Kendall, J. B., Lambert, R. W., and Nielson, S. M., "Preliminary Study of Multiple Fuel Processing at the PUREX Plant," HW-79665 (Richland, Washington: G.E. Hanford Co., November 26, 1963).

Kendall, W. R., "Plutonium Buy-Back Facility - Z Plant, FY-1966 Budget facility Description," HW-81542 (Richland, Washington: G.E. Hanford Co., March 30, 1964).

Kent, C. E., "Project Proposal, Expansion of 300 Area Production Facilities (Project CA-514)," HW-25906 (Richland, Washington: General Electric Nucleonics Division, October 15, 1952).

Kidder, C. P., "100-300 Area Program Meeting of May 7, 1946," HW-704049 (Richland, Washington Hanford Engineer Works, May 7, 1946).

Kidder, C. P., and Jordan, W. E., "100-B Unit Purge - Part-I - Pressure Drop Studies," HW-3-2224 (Richland, Washington: Hanford Engineer Works, April 16, 1945).

Koop, W. N.. "Removal of Ruptured Red Slug From Tube No. 4086-B," HW-21789 (Richland, Washington: G.E. Hanford Co., August 3, 1951).

Koop, W. N., "The Effect of Reactor Purges When River Temperature Exceeds 15 C," HW-50601 (Richland, Washington: G.E. Hanford Co., June 10, 1957).

Kratzer, W. K., "Acenaphthene Solvents for Use in Building 313 Frost Test Operation," HW-21450 (Richland, Washington: Hanford Engineer Works, June 26, 1951).

Kratzer, W. K., "Supplement F, Production Test IP-314-A, Measurement of Fuel Element Temperature Changes as the Result of Film Deposition," HW-67491 (Richland, Washington: G.E. Hanford Co., November 21, 1960).

Lane, T. V., "313 Building Fume Control Investigation Summary Report," HW-47260 (Richland, Washington: Hanford Atomic Products Operation, December 18, 1956).

Lattin, K. R., "Safety Study: Boiling Point Suppression and High Temperature Emergency Cooling System Instrumentation," UNI-3333 (Richland, Washington United Nuclear Industries, Inc., March 13, 1985).

Lechelt, J. A., "Engineering Report: Process Tube Flow Monitor System," UNI-2925 (Richland, Washington United Nuclear Industries, Inc., July 20, 1984).

Lee, P. J., "Qualification Test Procedure, Process Tube Removal Jack," UNI-4193 (Richland, Washington United Nuclear Industries, Inc., November 5, 1986). 
Lewis, W. R., "Process Tubes at B Pile," HW-07197 (Richland, Washington: G.E. Hanford Co., July 28,1947$)$.

Lewis, M., and Rohrbacher, R. A., "Severe Pitting Attack of Pile Process Tubes and Slugs," HW-29132 (Richland, Washington: G.E. Hanford Co., June 30, 1953).

Linschooten, C. G., "Controlled Development Plan: Cutter - Incore Detector Assembly in the Graphite Cooling System," UNI-4148 (Richland, Washington United Nuclear Industries, Inc., September 26, 1986).

Lovington, R. C., "Charge-Discharge During Pile Operation," HW-36224 (Richland, Washington: G.E. Hanford Co., April 14, 1955).

Lutton, J. M., "Sodium Dichromate as a Frocess Water Additive: An Evaluation," HW-27158 (Richland, Washington: G.E. Hanford Co., March 19, 1953).

Lyneis, C. A., "Construction Work Authorization, Project CG-692: Modifications to REDOX Plutonium Concentration Building - 233-S" (Richland, Washington: G.E. Hanford Co., June 18, 1957).

Lyon, L. W., "Evaluation of the Failed ECCS Primary Flush Line Piping Downstream of the V4-2 Valve," UNI-1986 (Richland, Washington United Nuclear Industries, Inc., February 26, 1982).

Lyon, L. W., "Status of the Tube Elongation Problem as of July, 1982," UNI-2110 (Richland, Washington United Nuclear Industries, Inc., January 26, 1983).

Lyons, T. H., "B-2076 - Metal Loader for "C" Elevator 100-B, D, DR, F, and H Areas," HW-40363 DEL (Richland, Washington: G.E. Hanford Co., December 8, 1955)

Lyons, T. H., "Project Proposal: Grounding of 2400-Volt Power Systems 100-B and D Areas (Project CAI-175)," RL-REA-676 (Richland, Washington: G.E. Hanford Co., May 7, 1965).

Lyons, T. H., "Project Proposal CGI-143 Fievision 1: Linear Power Rate-of-Rise Instrumentation 105-B,C and D," DUN-812 (Richland, Washington: Douglas United Nuclear, Inc., April 4, 1966).

Maider, J. E., and MacCready, W. K., "Report of Reactor Accidents," HW-10079 (Richland, Washington: G.E. Hanford Co., June 1, 1948).

Marshall, L. W., "Effect of Stainless Steel Thimbles on Pile Reactivity," HW-7-3212 (Richland, Washington: Hanford Engineer Works, December 14, 1945).

Martek, G. A., "Controlled Development Flan for Development/Fabrication of a Device for Characterization of Pressure Tube Inside Diameters," UNI-4263 (Richland, Washington United Nuclear Industries, Inc., May 5, 1987). 
Matsumoto, W. Y., "The Effect of Reactor Power Purges on Radioactive Contamination of Coolant," HW-43830 (Richland, Washington: G.E. Hanford Co., June 20, 1956).

McCarthy, P. B., "Interim Report: Cocked Slug, Flush-Charging Relations for C-Pile Conditions," HW-43456 (Richland, Washington: G.E. Hanford Co., June 29, 1956).

McCormack, J. D., and Schwendiman, L. C., "Significance of Rupture Debris in the Columbia River," HW-61325 (Richland, Washington: G.E. Hanford, Co., August 17, 1959)

McLenegan, D. W., "Flow Conditions at Outlet Fittings of Existing Hanford Reactors," HW-62729 (Richland, Washington: G.E. Hanford Co., November 12, 1959).

McMurray, P. R., "Columbia River Aspects of Increased Production," HW-41049 (Richland, Washington: G.E. Hanford Co., January 25, 1956).

Measley, H. F., "Increased Process Water Pressure to 105 Buildings," HW-20379

(Richland, Washington: G.E. Hanford Co., February 22, 1951).

Menegus, R. L., "Procedure for Improving Temperature Distribution Via Rods and Columns - B Pile," HW-7-2744 (Richland, Washington: Hanford Engineer Works, October 5, 1945).

Miller, N. R., "Production Test 105-525-E: The Effects of Water Quality on Pile Operation," HW-29406 (Richland, Washington: G.E. Hanford Co., September 21, 1953).

Mueller, E., "PUREX Ready for Next Step," in Hanford Reach (Richland, WA).

December 14, 1992.

Murphy, J. P., "Process Memo - Information on Dissolver Foaming/Burping/SpG Drops FY86-91," RHO-IL 37400-86-124 (Richland, Washington Rockwell Hanford Operations, May 30, 1986).

Murray, L. P., "Construction Completion and Cost Closing Statement" (Richland, Washington: G.E. Hanford Co., February 13, 1959).

National Academy of Sciences (NAS), "Radioactive Wastes at the Hanford Reservation: A Technical Review" (Washington, DC: NAS, 1978).

National Lead of Ohio, "Uranium Feed Materials Production Center," (Cincinnati, OH: National Lead of Ohio, Inc., 1984).

Nelson, R. L., "Inventory of the UNC Spent Fuel Basins," UNI-2046 (Richland, Washington United Nuclear Industries, April 23, 1982).

Nelson, R. L., "Procedure for Horizontal Control Rod Channel Distortion and Blockage Testing," UNI-3329 (Richland, Washington United Nuclear Industries, Inc.,

February 21, 1985).

Nelson, R. L., "Engineering Test Report: Horizontal Control Rod Testing," UNI-3422

(Richland, Washington United Nuclear Industries, Inc., May 2, 1985). 
Nelson, R. L., "Acceptance Test Procedure: Expanding Mandrel for Tube Removal," UNI-4191 Rev 1 (Richland, Washington United Nuclear Industries, Inc.,

February 23, 1987).

Newby, F. M., and Marshall, R. P., Jr., "Graphite Stack Inspection and Status Report, Calendar Year 1982," UNI-2109 (Richland, Washington United Nuclear Industries, Inc., May 2, 1983).

Nilson, R., "Reactor Hazards Review: Zirconium Re-tubing of Hanford Reactors," HW-63924 (Richland, Washington: G.E. Hanford Co., February 15, 1960).

Nolan, J. E., and Lorenzini, P. G., "Memorandum of Understanding (MOA): Use of 305 Building by Rockwell Hanford Operations for Process Facility Modifications" (Richland, Washington Rockwell Hanford Operations and Westinghouse Hanford Co., April 1985).

Olson, P. A., and Foster, R. F., "Accumulation of Radioactivity in Columbia River Fish in the Vicinity of Hanford Works," HW-23093 (Richland, Washington: G.E. Hanford Co., July 1, 1952).

Operation Managers, "Chemical Processing Department Monthly Report for January 1957," HW-48132 DEL (Richland, Washington: G.E. Hanford Co., February 21, 1957).

Operation Managers, "Chemical Processing Department Monthly Report for July 1957," HW-51802 DEL (Richland, Washington: G.E. Hanford Co., August 22, 1957).

Operation Managers, "Chemical Processing Department Monthly Report for December 1957," HW-54319 DEL (Richland, Washington: G.E. Hanford Co., January 21, 1958).

Operation Managers, "Hanford Laboratories Operation Monthly Activities Report, February 1959," HW-59463-A (Richland, Washington: G.E. Hanford Co., March 15, 1959).

Operation Managers, "Hanford Laboratories Operation Monthly Activities Report, April 1959," HW-60233-A (Richland, Washington: G.E. Hanford Co., May 15, 1959).

Operation Managers, "Hanford Laboratories Operation Monthly Activities Report, May 1959," HW-60505-A (Richland, Washington: G.E. Hanford Co., June 15, 1959).

Operation Managers, "Chemical Processing Department Monthly Report for December 1959," HW-63313 DEL (Richland, Washington: G.E. Hanford Co., January 21, 1960).

Operation Managers, "Chemical Processing Department Monthly Report for January 1960," HW-63706 DEL (Richland, Washington: G.E. Hanford Co., February 22, 1960).

Operation Managers, "Hanford Laboratories Operation Monthly Activities Report, February 1960," HW-64108-A (Richland, Washington: G.E. Hanford Co., March 15, 1960). 
Operation Managers, "Hanford Laboratories Operation Monthly Activities Report, July 1960," HW-66237 (Richland, Washington: G.E. Hanford Co., August 15, 1960).

Operation Managers, "Chemical Processing Department Monthly Report for August 1960," HW-66646 DEL (Richland, Washington: G.E. Hanford Co., September 21, 1960).

Operation Managers, "Hanford Laboratories Operation Monthly Activities Report, September 1960," HW-66960-DEL (Richland, Washington: G.E. Hanford Co., October 15, 1960).

Operation Managers, "Hanford Laboratories Operation Monthly Activities Report, November 1960," HW-67532 (Richland, Washington: G.E. Hanford Co.,

December 15, 1960).

Operation Managers, "Chemical Processing Department Monthly Report for March 1964," HW-81620 DEL (Richland, Washington: G.E. Hanford Co., April 21, 1964).

Operation Managers, "Chemical Processing [epartment Monthly Report for April 1964," HW-82089 DEL (Richland, Washington: G.E. Hanford Co., May 22, 1964).

Operation Managers, "Chemical Processing Department Monthly Report for May 1964," HW-82526 DEL (Richland, Washington: G.E. Hanford Co., June 22, 1964).

Operation Managers, "Chemical Processing Department Monthly Report for June 1964," HW-83102 DEL (Richland, Washington: G.E. Hanford Co., July 22, 1964).

Operation Managers, "Chemical Processing [epartment Monthly Report for December 1964," RL-SEP-197 DEL (Richland, Washington: G.E. Hanford Co., January 21, 1965).

Operation Managers, "Chemical Processing [lepartment Monthly Report for June 1965," RL-SEP-618 DEL (Richland, Washington: G.E. Hanford Co., July 21, 1965).

Operation Managers, "Chemical Processing Department Monthly Report for October 1965," RL-SEP-837 DEL (Richland, Washington: G.E. Hanford Co., November 22, 1965).

Operation Managers, "Chemical Processing Department Monthly Report for December 1965," RL-SEP-913 DEL (Richland, Washington: G.E. Hanford Co., January 21, 1966).

Operation Managers, "Hanford Laboratories Operation Monthly Activities Report, January 1959," HW-59099 (Richland, Washington: G.E. Hanford Co., February 15, 1959).

Operation Managers, "Hanford Laboratories Operation Monthly Activities Report, March 1959," HW-59717-A (Richland, Washington: G.E. Hanford Co., April 15, 1959).

Operation Managers, "Hanford Laboratories Operation Monthly Activities Report, December 1959," HW-63303 (Richland, Washington: G.E. Hanford Co., January 15,1960$)$. 
Operation Managers, "Hanford Laboratories Operation Monthly Activities Report, May 1960," HW-65459 (Richland, Washington: G.E. Hanford Co., June 15, 1960 ).

Operation Managers, "Hanford Laboratories Operation Monthly Activities Report, June 1960," HW-65854 (Richland, Washington: G.E. Hanford Co., July 15, 1960).

Operation Managers, "Hanford Laboratories Operation Monthly Activities Report, August 1960," HW-66644-DEL (Richland, Washington: G.E. Hanford Co., September 15, 1960).

Operation Managers, "Hanford Laboratories Operation Monthly Activities Report, October 1960," HW-67254 (Richland, Washington: G.E. Hanford Co., November 15,1960 ).

Operation Managers, "Hanford Laboratories Operation Monthly Activities Report, December 1960," HW-67954 (Richland, Washington: G.E. Hanford Co., January 15,1961 ).

Parker, H. M., "Note on Production Test 105-417-P-Document HW-20717," HW-20959 (Richland, Washington: G.E. Hanford Co., April 30, 1951).

Parker, H. M., "The Columbia River Situation - A Semi-Technical Review," HW-32809 (Richland, Washington: G.E. Hanford Co., August 19, 1954).

Parnell, M. A., "Functional Design Criteria - PUREX Piping and Operating Gallery Services Upgrade (Project B-205)," RHO-CD-282 Riev. 2 (Richland, Washington Rockwell Hanford Operations, May 1981).

Paul, R. S., and Stephens, D. E., "Continuous Effluent Water High Temperature Monitor for B, C, D, DR, F and H Piles," HW-34467 (Richland, Washington: January 17, 1955).

Pearl, W. L., "Expansion of Water Treatment Facilities - 100 Areas," HW-28739 (Richland, Washington: G.E. Hanford Co., July 20, 1953).

Pitzer, E.C., "Anodization of Process Tubes," HW-25656 (Richland, Washington: G.E. Hanford Co., September 17, 1952).

Platt, A. M., and Tomlinson, "Processing E-Metal in the 200 Areas," HW-46138 (Richland, Washington: G.E. Hanford Co., October 19, 1956).

Pope, M. I., "Acceptance Test Procedures for the Process Tube Drying System," UNI-4239 (Richland, Washington United Nuclear Industries, Inc., January 20, 1987).

Porter, W. W., "Request for Mechanical Development to Improve Ball 3X Removal Equipment (B, D, DR, F and H Reactors)," (Richland, Washington: G.E. Hanford Co., November 17, 1958). 
Prosk, W., "Green Slug Monitor Proof of Principle Test: Hazards Identification and Evaluation," SD-HS-SAR-013 (Richland, Washington Rockwell Hanford Operations, April 7, 1983).

Prosk, W., "PUREX Plant Equipment Decontamination and Repair Unit (Project B-422): Hazards Identification and Evaluation," SD-HS-SAR-006 (Richland, Washington Rockwell Hanford Operations, February 1984).

PUREX Process Subsection, ISOCHEM Company, "PUREX Plant: Thorium Process operation Report," ISO-419 (HAN-99290) (Richland, Washington ISOCHEM Inc., December 1967).

"PUREX Resumes Operation," in Tri-City Herald, April 27, 1988, p. C7.

Quinn, G. F., "Administrative Limits on Reactor Power Levels," HAN-73578 (Washington D.C.: U. S. Atomic Energy Commission, October 8, 1959).

Raile, M. N., "Conceptual Design Report, Structural Upgrading - PUREX Plant, 200 East, Project B-336," RHO-CD-1262 CDR (Richland, Washington Rockwell Hanford Operations, January 1982).

Rainey, T. E., "Engineering Study, Reactor Coolant System Control Valves, NPFR Project H-600," UNI-2182 (Richland, Washington United Nuclear Industries, Inc., September 27, 1982).

Rasmussen, D. E., "Reactor Surveillance Equipment Evaluation," UNI-3583 (Richland, Washington United Nuclear Industries, Inc., January 1986).

Reberger, D. W., "PUREX Product Removal Fioom Upgrade," RHO-CD-1418 (Richland, Washington Rockwell Hanford Operations, April 1981).

Reeves, J. A., "Functional Design Criteria, 105-N Fuel Rupture Monitor Sample Water Reinjection System. Project H-516," UNI-610 Rev. 1 (Richland, Washington United Nuclear Industries, Inc., June 27, 1983).

Reid, R. W., "Recommended Tube Flow Limitations for B and D Pile Downcomers," HW-57497 (Richland, Washington: G.E. Hanford Co., September 17, 1958).

Reinker, P. H., "Report on Additional Production Capacity of Hanford Works Factors Involved in Case II and Case III," HW-22110 (Richland, Washington: G.E. Hanford Co., August 8, 1951).

Reinker, P. H., and Bupp, L. P., " 100 Area Process Improvement Program for the Period November 1954 Through April 1955," HW-33842 (Richland, Washington: G.E. Hanford Co., November 19, 1954)

Renn, W. A., "Hanford Reactor Operating Characteristics: Physical Descriptions Current Design Limits And Fuel Element Glossary," HAN-65347 (Richland, Washington: G.E. Hanford Co., April 11, 1957). 
Richman, R. B., "Development Test 105-558-E: Evaluation of High Na2O Neutralization in Activated Silica Preparation," HW-37694 (Richland, Washington: G.E. Hanford Co., June 30,1955$)$.

Richman, R. B., "Water Treatment History at Hanford Reactors Thru August 20, 1956," HW-45070 (Richland, Washington: G.E. Hanford Co., August 21, 1956).

Rieck, H. G., "Pilot Scale Aluminum Bed Decontamination of Reactor Effluent," HW-72215 (Richland, Washington: G.E. Hanford Co., March 1962).

Ritchey, H. W., "Process Water Specifications, GED-13," HW-12492 (Richland, Washington: G.E. Hanford Co., December 1, 1948).

Robbins, F. D., "Reliability and Safety of the Electrical Power Supply Complex of the Hanford Production Reactors," HW-6636:3 (Richland, Washington: G.E. Hanford Co., September 15, 1960).

Roemer, J. J., "PUREX Plant Final Safety Analysis report," WHC-SD-HS-SAR-001, Rev. 5 (Richland, Washington Westinghouse Hariford Co., January 1987).

Rohrmann, C. A., and Ludlow, J. O., "Process Modifications 202-S Building," HW-27968 (Richland, Washington: G.E. Hanford Co. May 5, 1953).

Russ, M. H., "Design Criteria - Reactor Plant Modifications For Increased Production and 100-C Area Alterations Sections A and B," HW-30401, Vol. 1 (Richland, Washington: G.E. Hanford Co., August 10, 1954).

Schiffman, R. H., "The Uptake of Strontium from Diet and Water by Rainbow Trout," HW-72107 (Richland, Washington: G.E. Hanford Co., December 1961).

Schilling, R. D., and Hess, K. W., Final Report, Production Test No. 105-1-MR: Poison Column Control During Reactor Operation," HW-25082 (Richland, Washington: G.E. Hanford Co., July 24, 1952).

Schilling, R. D., "Process Test MR-105-19: Evaluation of the Slip Joint, C-Reactor Rear Pigtail Replacement," HW-31519 (Richland, Washington: G.E. Hanford Co., April 20, 1954).

Schofield, J. S., "lodine Monitoring and Riemoval Requirements-During processing of fast Flux Test Facility Fuel in PUREX," WHC IM 14300-88-110 (Richland, Washington Westinghouse Hanford Co., November 7, 1988).

Schroeder, O. C., "C Reactor Tube Power Limits," HW-31717 (Richland, Washington: G.E. Hanford Co., April 30, 1954).

Scott, K. V., "N-Reactor Pressure Tube Curvature Effects," UNI-1960 (Richland, Washington United Nuclear Industries, Inc., February 5, 1982). 
Section Managers, "Chemical Processing Division Monthly Report for February 1966," ISO-143 DEL (Richland, Washington Isochem, Inc., March 21, 1966).

Section Managers, "Chemical Processing Division Monthly Report for March 1966," ISO-210 DEL (Richland, Washington Isochem, Inc., April 22, 1966).

Section Managers, "Chemical Processing Division Monthly Report for April 1966," ISO-276 DEL (Richland, Washington Isochem, Inc., May 20, 1966).

Section Managers, "Chemical Processing Division Monthly Report for May 1966," ISO-315 DEL (Richland, Washington Isochem, Inc., June 20, 1966).

Section Managers, "Chemical Processing Division Monthly Report for June 1966," ISO-365 DEL (Richland, Washington Isochem, Inc., July 21, 1966).

Shaw, D. S., "Expansion of 234-5 Facilities (Project No. CG-551)," Directive No. HW-305 (Richland, Washington U.S. Atomic Energy Commission, June 3, 1953).

Shaw, D. S., "Activate Task I, RMA Line, Building 234-5 (Project No. CG-549)," Directive No. HW-304 (Richland, Washington U.S. Atomic Energy Commission, April 29, 1953).

Shaw, D. S., "Activate Task 1, RMA Line, Building 234-5 (Project No. CG-549)," Directive No. HW-304, Modification No. 1 (Richland, Washington U.S. Atomic Energy Commission, January 7, 1954).

Shaw, D. S., "Activate Task 1, RMA Line, Building 234-5 (Project No. CG-549)," Directive No. HW-304, Modification No. 2 (Richland, Washington U.S. Atomic Energy Commission, June 29, 1954).

Shaw, H. P., "Physical Completion Notice: Plutonium Buy-Back Facility, Project CGC-180" (Richland, Washington Isochem, Inc., May 26, 1966).

Shoemaker, D. C., "Functional Design Criteria - PUREX Laboratory HVAC Upgrade (Project B-345)," RHO-CD-1259 FDC (Richland, Washington Rockwell Hanford Operations, May 1981 ).

Shoemaker, R. H., and Fuller, R. E., "Thermal Hydraulic Bases for Four-Cell Operation," UNI-2016 (Richland, Washington United Nuclear Industries, Inc., March 30, 1982).

Silker, W. B., "A Feasibility Study on the Reduction of P32 and As76 Concentrations in Reactor Effluent Water," HW-56366 (Richland, Washington: G.E. Hanford Co., June 12, 1958).

Silker, W. B., "Water Treatment Variables - Nitrate System," BNWL-CC-1055 (Richland, Washington: Battelle Northwest Laboratories, February 1967).

Simsen, C. A., "Plant Work Forces Review: Linear Power Rate-of-Rise Instrumentation," IP64-15 (Richland, Washington: G.E. Hanford Co., November 11, 1963). 
Sivula, C., "Watkins Orders Standby for PUREX," in Tri-City Herald, October 17, 1990, p. A1.

Sloat, R. J., "Operational Characteristics of the PUREX and REDOX Plutonium Continuous Concentrator Package," HW-27796 (Richland, Washington: G.E. Hanford Co.,

April 21, 1953).

Sloat, R. J., "RMA-RMC Button Line Process Specifications and Operating Standards," RL-SEP-589 (Richland, Washington: G.E. Hanford Co., June 25, 1965).

Smith, C. M., "Test Report of OTP UNI-4047, Testing the VOTAW and Original V-11 Vanes," UNI-4253 (Richland, Washington United Nuclear Industries, Inc., January 23,1987$)$.

Smith, P. W., "The Zirflex Process Terminal Development Report," HW-65979 (Richland, Washington: G.E. Hanford Co., August 20, 1960).

Spies, K. H., "Columbia River Environmental Radiological Survey: Interim Progress Report," CIC-161740 (Salem, OR: Oregon State Board of Health, September 1961).

Spies, K. H., "Lower Columbia River Environmental Radiological Survey in Oregon Progress Report - July Through September, 1962," CIC-161731 (Salem, OR: Oregon State Board of Health, November 19, 1962).

Stainken, F. A.. "Steam Loss at 190 B, D, DR, F and H Buildings," HW-35589 (Richland, Washington: G.E. Hanford Co., February 25, 1955).

Stapp, D. C., and Marceau, T. E., "The Hanford Site N Reactor Buildings Task Identification and Evaluation of Historic Properties," BHI-00627 Rev. O (Richland, Washington Bechtel Hanford Inc., January 1996).

Stark, B. M., "Investigation of 100 Areas Storage and Transportation of Irradiated Uranium," HW-22824 (Richland, Washington: G.E. hanford Co., November 13, 1951 ).

Starkebaum, N. V., "Process Test MR-105-25: Reactor Purge at Low Concentrations," HW-33698 (Richland, Washington: G.E. Hanford Co., November 5, 1954).

Stauch, D. J., "Controlled Development Plan for Graphite Cooling Tube Surveillance and Removal," UNI-4210 (Richland, Washington United Nuclear Industries, Inc.,

December 4, 1986).

Stoller, S. M., and Richards, R. B., eds., Reactor Handbook, 2nd ed. (New York: Interscience Publishers Inc., 1961).

Strand, N. O., "Maximum Capacities of the 100-B Water Plant," HW-27778 (Richland, Washington: G.E. Hanford Co., April 27, 1953). 
Strege, D. E., "Interim Report, Production Test 105-522-E, Examination of Pile Process Tubes Removed From 100-B, C and D Piles," HW-32960 (Richland, Washington: G.E. Hanford Co., September 3, 1954).

Streid, D. D., "234-5 Building Program Review," HM-253 (Richland, Washington: G.E. Hanford Co., April 22, 1949).

Sullivan, J. L., "N Reactor Production Test and Development Test Status Report," UNI-4225 (Richland, Washington United Nuclear Industries, Inc., December 16, 1986).

Swartout, J. A., "Source of High Activity Levels Recently Observed from Shipping Containers and Transfer Cans," HW-3-2801 (Richland, Washington Hanford Engineer Works, July 5, 1945).

Talbott, J. W., "Operating History of Hanford Piles," HW-37304 (Richland, Washington: G.E. Hanford Co., June 15, 1955).

Thomas, J. I., "RMC Button Line - 234-5 Building (Project No. CG-734)," Directive No. HW-426 (Richland, Washington U.S. Atomic Energy Commission, April 8, 1957).

Thorne, W. L., "Battelle Northwest Thermal Hydraulics Laboratory," BNWL-SA-1770 (Richland, Washington Battelle North West laboratory, April 11, 1968).

Tomlinson, R. E., "Special Study - Separations Considerations," HW-60892-RD (Richland, Washington: G.E. Hanford Co., October 18, 1955).

Toyoda, K. G., "Description of Transient System, High Pressure Heat Transfer Apparatus 189D," HW-71389 (Richland, Washington: G.E. Hanford Co., October 23, 1961).

Travis, J. E., "RMC Fabrication Line - 234-5 Building (Project No. CG-745)," Directive No. HW-427 (Richland, Washington U.S. Atomic Energy Commission, April 3, 1957).

Travis, J. E., "RMC Fabrication Line - 234-5 Building (Project No. CG-745)," Directive No. HW-427, Modification \#1 (Richland, Washington U.S. Atomic Energy Commission, November 8,1957 ).

Travis, J. E., "RMC Fabrication Line - 234-5 Building (Project No. CG-745)," Directive No. HW-427, Modification \#2 (Richland, Washington U.S. Atomic Energy Commission, November 21, 1957).

Travis, J. E., "RMC Button Line - 234-5 Building (Project No. CG-734)," Directive No. HW-426, Modification \#1 (Richland, Washington U.S. Atomic Energy Commission, January 10,1958 ).

Travis, J. E., "RMC Fabrication Line - 234-5 Building (Project No. CG-745)," Directive No. HW-427, Modification \#3 (Richland, Washington U.S. Atomic Energy Commission, June 24, 1958). 
Travis, J. E., "RMC Button Line - 234-5 Building (Project No. CG-734)," Directive No. HW-426, Modification \#2 (Richland, Washington U.S. Atomic Energy Commission, December 12,1958 ).

Travis, J. E., "RMC Fabrication Line - 234-5 Building (Project No. CG-745)," Directive No. HW-427, Modification \#4 (Fichland, Washington U.S. Atomic Energy Commission, April 15, 1959).

Travis, J. E., "RMC Button Line - 234-5 Building (Project No. CG-734)," Directive No. HW-426, Modification \#3 (Richland, Washington U.S. Atomic Energy Commission, October 1, 1959).

Travis, J. E., and Bloch, E. J., "Limits to the Hanford Reactor Power Levels," HAN-71403 (Richland, Washington U.S. Atomic Energy Commission, February 1959).

Trumble, R. E., "Review of Hanford Production Reactor Confinement (Project CGI-791), HW-67131 (Richland, Washington: G.E. Hanford Co., October 14, 1960).

Trumble, R. E., "Hazards Summary Report - Projects CG-558 and CG-600 Reactor Plant Modifications Volume 1," HW-44708 Vol. 1 (Richland, WA; G.E. Hanford Co., April 2, 1957).

Trumble, R. E., "Hazards Summary Report - Projects CG-558 and CG-600 Reactor Plant Modifications Volume 2, Appendices," HW-44708 Vol. 2 (Richland, Washington: G.E. Hanford Co., December 21, 1957).

Trumble, R. E., "Hazards Review Power Level Limits For Hanford Reactor," HW-61580 (Richland, Washington: G.E. Hanford Co., August 17, 1959).

U.S. Atomic Energy Commission (AEC), "A History of the Expansion of AEC Production Facilities," AEC-1140 (Washington, DC: U.S. Atomic Energy Commission, August 1963).

U.S. Department of Energy (DOE), "The 300 Area Waste Acid Treatment System Closure Plan," DOE/RL-90-11 (Richland, Washington: U.S. DOE, June 1990).

U.S. Department Of Energy, "Historical Release Report for the Rocky Flats Plant, Final" (Golden, CO: U.S. Department of Energy, June 1992).

U.S. Energy Research and Development Administration (ERDA), "Waste Management Operations, hanford Reservation: Final Environmental Statement," ERDA-1538 (Richland, Washington U.S. ERDA, December 1975).

Upson, U. L., "Detection of Tube Leaks in Piles," HW-63562 (Richland, Washington: G.E. Hanford Co., January 20, 1960).

Van Meter, R. A., "Uranium Nitrate Hexahyydrate (UNH) Trailer," RHO-CD-1349 FDC (Richland, Washington Rockwell Hanford Operations, July 1981 ). 
WHC-MR-0521, Rev. 0

Vitro Engineering Corporation, "Conceptual Design Report, PUREX Backup Generators, Project B-382," RHO-CD-1269 CDR (Richland, Washington Rockwell Hanford Operations, September 1981).

Wahlen, R. K., "History of 100-B Area," WHC-EP-0273 (Richland, Washington: Westinghouse Hanford Co., October 1989).

Walker, R. C., "Re-Evaluation of Ball 3X Recovery System Improvements 105-B, D, DR, F and $\mathrm{H}$," HW-50351-DEL (Richland, Washington: Westinghouse Hanford Co., May 27, 1957).

Walser, R. W., and Lyon, R. Y., "Z-Plant Weekly Report: Task I-II \& Recovery Operations, January 1, 1964 through December 31, 1964," HW-80356 RD (Richland, Washington: G.E. Hanford Co., January 2, 1965).

Walser, R. W., and Lyon, R. Y., "Z-Plant Weekly Report: Task I-II and Recovery Operations, January 1, 1965 through December 31, 1965," RL-SEP-249 RD (Richland, Washington: G.E. Hanford Co., January 1, 1966).

Warekois, E. P., and Reinker, P. H., "Interim Report on Pile Graphite Sampling Production Tests: Pile Graphite Expansion," HW-19281 (Richland, Washington: G.E. Hanford Co., October 23, 1950).

Warren, J. H., "Chemical Form of Plutonium Buy Back," HW-76496 (Richland, Washington: G.E. Hanford Co., February 7, 1963).

Warren, J. N., "Development of New Methods for Removing Ruptured Slugs," HW-22423 (Richland, Washington: G.E. Hanford Co., October 12, 1951).

Washington State Dept. of Health, "Project Proposal For a Radiological Health Study," CIC-0161754 (Olympia, WA: Washington State Dept. of Health, February 20, 1961).

Watson, D. F., Fox, J. M., Jr. Harrison, C. W., Kempf, F. J., and Reinig, L. P., "Existing Reactor Rear Face Piping Review," HW-65269 (Richland, Washington: G.E. Hanford Co., May 25, 1960).

Watson, D. J., Brendel, D. F., and Shields, K. D., "Facility Effluent Monitoring Plan for the N Reactor," WHC-EP-0477 (Richland, Washington Westinghouse Hanford Co., 1991).

Weakley, E. A., "Preliminary Evaluation of Pennsalt A-10 and Turco 'Aviation' Cleaner for Cleaning Aluminum Caps and Cans," HW-24494 (Richland, Washington: Hanford Atomic Products Operation, May 19, 1952).

Weakley, E. A., "Effect of Diversey 514 in Methanol, " HW-27321 (Richland, Washington: Hanford Atomic Products Operation, March 5, 1953).

Weakley, E. A., "Evaluation of Etchants for Deoxidizing Aluminum Components," HW-27734 (Richland, Washington: Hanford Atomic Products Operation. April 15, 1953). 
Weakley, E. A. "Technology of the HAPO Lead Dip Fuel Element Canning Process," HW-58115 DEL (Richland, Washington: Hanford Atomic Products Operation, December 15,1958 ).

Wells, H. T., "Installation of Reactor Gas Refrigeration System - 105-C Project C-431," HW-27318 (Richland, Washington: G.E. Hanford Co., March 5, 1953).

Wende, C. W. J.. "Production Test No. 305-9-P: Poisoning Effectiveness and Uniformity of Myrnalloy Slugs," HW-7-3486 (Richland, Washington: Hanford Engineer Works, February 19, 1946).

Wende, C. W. J., "Final Report Production Test No. 305-9-P: Poisoning Effectiveness and Uniformity of Myrnalloy Slugs," HW-7-3834 (Richland, Washington: Hanford Engineer Works, April 2, 1946).

Wende, C. W. J., "Pile Operation at Higher Power," HW-13184 (Richland, Washington: G.E. Hanford Co., March 31, 1949).

Williams, B., and J. C. Williamson, "Process Flow - Accountability - Normal Uranium in 300 Area Using Triple Dip Process," H-3-08393 (Richland, Washington: Hanford Atomic Products Operation, September 8, 1954).

Wilson, C. D., "Investigation of Severe Pitting of Slugs and Tubes in the Hanford Piles, " HW-31043-Rev (Richland, Washington: G.E. Hanford Co., June 7, 1954).

Windsheimer, W. W., "History of the Reactivation of 100-B Pile," HW-11374 (Richland, Washington: G.E. Hanford Co., October 29, 1948).

Windsheimer, W. W., "Pile Level Objectives," HW-20841 (Richland, Washington: G.E. Hanford Co., April 16, 19511.

Woods, W. C. A., "AEC Research and Development Report Final Report Production Test No. 105-473-P The Use of Aluminum Sulfate For 100 Areas' Process Water Coagulation," HW-23163 (Richland, Washington: G.E. Hanford Co., January 4, 1952).

Woods, W. C. A., "Final Report: The Use of Alum and Activated Silica for 100 Area Process Water Coagulation," HW-37698 (Richland, Washington: G.E. Hanford Co., July 15, 1955).

Yoder, R. A., "233-S Information Manual (Project CGC-913)" (Richland, Washington: G.E. Hanford Co., July 16, 1962).

Yost, G. F., "Spontaneous Decomposition of Trichloroethylene," HW-39945 (Richland, Washington: Hanford Atomic Products Operation, November 15, 1955).

Young, J. R., "The Effect of Operational Charge-Discharge on the Slug Rupture Limit," HW-43343 DEL (Richland, Washington: G.E. Hanford Co., June 6, 1956). 
Young, J. R., "Operational Problems of the Original Hanford Production Reactor," HW-56230-RD (Richland, Washington: G.E. Hanford Co., July, 10, 1958).

Young, J. R., "Current Status - Second Generation Process Tube Internal Corrosion," HW-65760 (Richland, Washington: G.E. Hanford Co., June 22, 1960).

Young. J. R., "Reactor Process Channel Water Leak History FY 1959 and 1960," HW-66468 (Richland, Washington: G.E. Hariford Co., August 17, 1960).

Zaloudek, F. R., and Ruff, E. S., "Pressure Tube Testing Test Plan Document Production Assurance Program," UNI-3653 (PNL-5924) (Richland, Washington: United Nuclear Industries, April 1986).

Zaloudek, F. R., and Ruff, E. S., "Zirconium Pressure Tube Testing, Test Procedures Production Assurance Program (Project H-700)," UNI-3994 (PNL-5930) (Richland, Washington: United Nuclear Industries, June 1986). 
WHC-MR-0521, Rev. 0

\section{DISTRIBUTION}

Number of copies

\section{ONSITE}

1

WHC Central Files

A3-88

1

Document Processing Center (DPC)

A3-94 
THIS PAGE INTENTIONALLYY LEFT BiANKK. 